\title{
1,5-disubstituted 1,2,3-triazoles as amide bond isosteres yield novel tumor-targeting minigastrin analogs
}

Nathalie M. Grob, ${ }^{[a]}$ Roger Schibli, ${ }^{[a, b]}$ Martin Behe, ${ }^{*[b], ~ I b a i ~ E . ~ V a l v e r d e, ~}{ }^{*[c]}$ and Thomas L. Mindt ${ }^{*[d, e, f]}$

a Department of Chemistry and Applied Biosciences, ETH Zurich, 8093 Zürich (Switzerland)

${ }^{b}$ Center for Radiopharmaceutical Sciences, Division of Biology and Chemistry, Paul Scherrer Institute, 5232 Villigen (Switzerland)

' Institut de Chimie Moléculaire de I'Université de Bourgogne, UMR 6302, CNRS, Univ. Bourgogne FrancheComté, 9, Avenue Alain Savary, 21078, Dijon Cedex, France

${ }^{\mathrm{d}}$ Ludwig Boltzmann Institute Applied Diagnostics, General Hospital of Vienna, 1090 Vienna (Austria)

e Department of Inorganic Chemistry, Faculty of Chemistry, University of Vienna, 1090 Vienna (Austria)

$\mathrm{f}$ Department of Biomedical Imaging and Image Guided Therapy, Medical University of Vienna, 1090 Vienna (Austria)

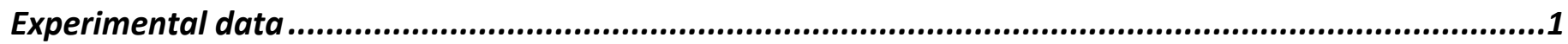

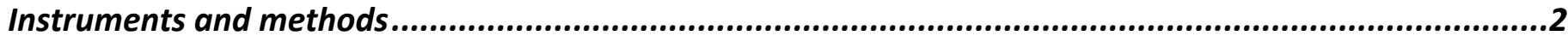

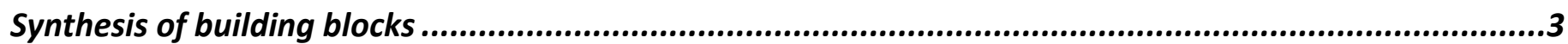

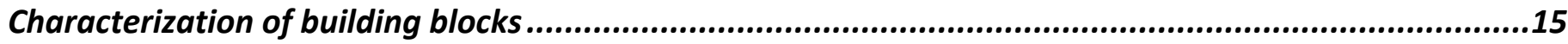

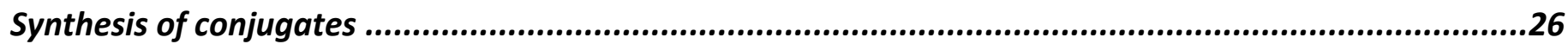

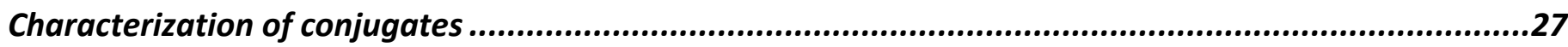

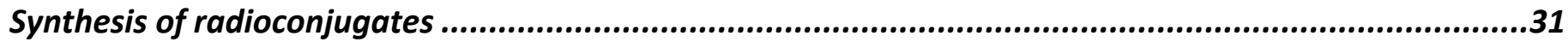

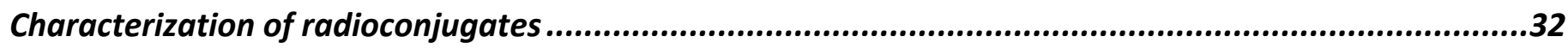

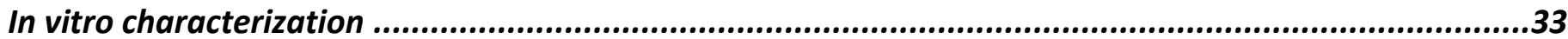

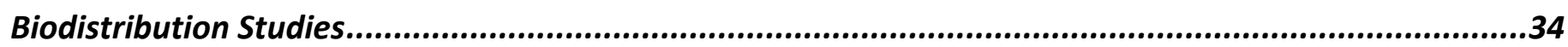

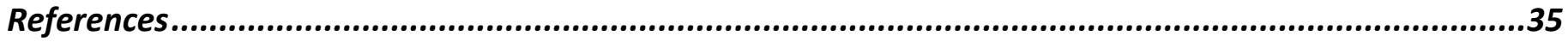




\section{Experimental data}

Fmoc-amino acids, Boc-amino acids, Rink Amide resin (100-200 mesh), HATU, TBTU and BOP were purchased from Iris Biotech $\mathrm{GmbH}$. Solvents were purchased from VWR, or Carlo Erba. All other chemicals were from Sigma Aldrich, Acros organics, or Fisher Scientific (Reinach, Switzerland). Ru catalyst was purchased from Strem Chemicals. DOTA(tris-tBu) ester was a gift from Chematech (Dijon, France). Polypropylene frits were obtained from Roland Vetter Laborbedarf OHG (Ammerbuch, Germany), and teflon taps from Biotage (Uppsala, Sweden). Media and supplements for cell culture were bought from BioConcept (Allschwil, Switzerland) and VWR (Dietikon, Switzerland). Human blood plasma (type $A^{+}$) for stability experiments was bought from the blood donation center (Aarau, Switzerland), and aliquots of $4 \mathrm{~mL}$ were stored at $-80{ }^{\circ} \mathrm{C}$. Minigastrin (H-Leu-Glu-Glu-Glu-Glu-Glu-Ala-Tyr-Gly-Trp-Met-Asp-Phe-NH ${ }_{2}$ ) and PP-F11N (DOTA-(DGlu) 6 -AlaTyr-Gly-Trp-Nle-Asp-Phe- $\mathrm{NH}_{2}$ ) were ordered from Peptide Specialty Laboratories (Heidelberg, Germany). $\left[{ }^{177} \mathrm{Lu}\right] \mathrm{LuCl}_{3}$ was ordered from ITM (Garching, Germany). The synthesis and biological evaluation of 1,4-Tz MGs 2, 3, and 4 has been described in detail in Grob et al., J Med Chem, 2020. ${ }^{1}$

Unless noted otherwise, all commercially available reagents and solvents were used without further purification. Dicalite was purchased from Carlo Erba. TLC were carried out on Merck DC Kieselgel 60 F-254 aluminum sheets. The spots were directly visualized or through illumination with a UV lamp ( $\lambda=254 \mathrm{~nm}$ ). Column chromatography purifications were performed manually on silica gel (40-63 $\mu \mathrm{m}$ ) from Sigma-Aldrich (technical grade). Dry solvents (HPLC-grade) were dried over alumina cartridges using a solvent purification system PureSolv PS-MD-5 model from Innovative Technology. Peptide synthesis-grade DIEA and TFA were provided by Iris Biotech $\mathrm{GmbH}$. HPLC-grade $\mathrm{CH}_{3} \mathrm{CN}$ used for HPLC-MS analyses was obtained from Carlo Erba. $\mathrm{CH}_{3} \mathrm{CN}$ used in semi-preparative RP-HPLC purifications was obtained from Biosolve or VWR (technical, >99\% but distilled prior to use). All aq. mobile phases for HPLC were prepared using water purified with a PURELAB Ultra system from ELGA (purified to $18.2 \mathrm{M} \Omega . \mathrm{cm}$ ).

Yields were calculated based on isolation of the compounds.

A431-CCK2R cells ${ }^{2}$ were provided by Dr. Luigi Aloj (Department of Radiology, University of Cambridge, Cambridge, United Kingdom). Female CD1/nu mice were ordered from Charles River Laboratories (Sulzfeld, Germany). All experiments involving animals were in compliance with Swiss laws on animal protection and approved by the cantonal Veterinary Office of the canton of Aargau (license number AG 75700).

\section{Instruments and methods}

Lyophilization was performed with a Christ Alpha 2-4 LD plus.

${ }^{1} \mathrm{H}$-, and ${ }^{13} \mathrm{C}$ - NMR spectra were recorded on Bruker spectrometers, an Avance Neo $500 \mathrm{MHz}$ equipped with a $5 \mathrm{~mm}$ BBOF iProbe and Avance III HD $600 \mathrm{MHz}$ equipped with a $5 \mathrm{~mm}$ BBOF $\mathrm{N}_{2}$ cryoprobe. Chemical shifts are expressed in parts per million (ppm) from the residual non-deuterated solvent signal summarized in 2010 by Fulmer et al. ${ }^{3}$ Coupling constants $(J)$ are reported in hertz $(\mathrm{Hz})$. Standard abbreviations indicating multiplicity were used as follows: $\mathrm{s}=$ singlet, $\mathrm{d}=$ doublet, $\mathrm{t}=$ triplet, $\mathrm{q}=$ quadruplet, $\mathrm{m}=$ multiplet, $\mathrm{br}=$ broad. IR spectra were recorded with a Bruker Alpha FT-IR spectrometer equipped with a universal ATR sampling accessory. The bond vibration frequencies are expressed in reciprocal centimeters $\left(\mathrm{cm}^{-1}\right)$.

High-resolution mass spectrometry analyses were recorded on a LTQ Orbitrap XL mass spectrometer (Thermo Scientific) equipped with an electrospray ionization source (HESI 2). The following source parameters were used if no further specification is mentioned: Heater Temperature: $50{ }^{\circ} \mathrm{C}$, Gas Flow: Sheath 15 / Aux 10 / Sweep 0, Spray Voltage: 4 kV, Capillary Temperature: $275^{\circ} \mathrm{C}$, Capillary Voltage: $22 \mathrm{~V}$, Resolution $(\mathrm{m} / \mathrm{z}=400): 60000$.

Optical rotations were recorded on an Anton Paar MCP100 equipped with a $100 \mathrm{~mm}$ stainless steel cell. 
HPLC-MS analyses were performed on a Thermo-Dionex Ultimate 3000 instrument (pump + autosampler at $20{ }^{\circ} \mathrm{C}+$ column oven at $25^{\circ} \mathrm{C}$ ) equipped with a diode array detector (Thermo-Dionex DAD 3000-RS) and a MSQ Plus single quadrupole mass spectrometer. The corresponding low-resolution mass spectra (LRMS) were recorded with this latter mass spectrometer, with an electrospray (ESI) source (HPLC-MS coupling mode). HPLC systems were equipped with a Phenomenex Kinetex C18 column, $2.6 \mu \mathrm{m}, 2.1 \times 50 \mathrm{~mm}$ or a Jupiter Proteo $4 \mu \mathrm{m} 90$ Å column, $250 \times 4.6 \mathrm{~mm}$.

Purifications by semi-preparative HPLC were performed on a Thermo-Dionex Ultimate 3000 instrument equipped with a RS Variable Detector (four distinct wavelengths). HPLC system was equipped with a Jupiter Proteo $4 \mu \mathrm{m} 90 \AA ̊$ column ( $250 \times 21.2 \mathrm{~mm}$, AXIA packed).

Gamma-HPLC was performed on a Varian ProStar HPLC system monitored by UV-detection at $215 \mathrm{~nm}$ and a Packard Radiomatic Flo-One Beta radio detector using a Dr. Maisch ReproSil-Pur C18-AQ column (3 $\mu$ m, 100 $x 4.6 \mathrm{~mm}$, flow $1.2 \mathrm{~mL} / \mathrm{min}$ ) for quality control of radiolabeling reactions and a Sigma-Aldrich Supelco Discovery C18 column ( $5 \mu \mathrm{m}, 250 \times 4.6 \mathrm{~mm}$, flow $1.2 \mathrm{~mL} / \mathrm{min}$ ) for analysis of radioactive metabolites with mobile phases $\mathrm{A}, \mathrm{CH}_{3} \mathrm{CN}+0.1 \%$ TFA, and $\mathrm{B}, \mathrm{H}_{2} \mathrm{O}+0.1 \%$ TFA.

Chiral HPLC analysis were performed on a Shimadzu RP-HPLC analytical system including an absorbance detector SPD-10A, a solvent delivery unit LC-10AT, an autosampler SIL-10AD, a system controller CBM-20A, and a column oven CTO-10AS, recorded at $254 \mathrm{~nm}$ or $301 \mathrm{~nm}$ using a mixture of $n$-hexane and iso-propanol as mobile phase.

The concentrations of stock solutions of compounds 5, 6, and 7 were determined by a NanoPhotometer P360 (IMPLEMEN, Munich, Germany) with measurements of UV absorption at $\lambda=280 \mathrm{~nm}$ using $\varepsilon=$ $6990 \mathrm{~L} \cdot \mathrm{mol}^{-1} \cdot \mathrm{cm}^{-1}$, calculated by ExPASy (ProtParam of the Swiss Institute of Bioinformatics (https://web.expasy.org/protparam) for H-EAYGWNleDF-NH ${ }_{2}$ ).

$0.5 \mathrm{~mL}$ protein low-binding Eppendorf tubes were used for (radio)metal labeling with heating and shaking by an Eppendorf Thermomixer comfort (Eppendorf, Hamburg, Germany). Any centrifugation required during in vitro experiments was performed by an Eppendorf $5415 \mathrm{C}$ centrifuge (Eppendorf, Hamburg, Germany). 
(9H-fluoren-9-yl)methyl-(but-3-yn-2-yl)carbamate (8)<smiles>C#CC(C)NOC(F)F</smiles>

The compound was synthesized as previously described. ${ }^{1}$ However, despite having followed the same conditions, we observed a partial racemization of the amino alkyne during the synthesis. This phenomenon was characterized by two different methods.

a) Alkyne $\mathbf{8}$ was analyzed by chiral HPLC.

Conditions: Column Daicel Chiralpak IA, Hexane/iPrOH =98/2, $1 \mathrm{~mL} / \mathrm{min}$ at $254 \mathrm{~nm}$. $\mathrm{mV}$

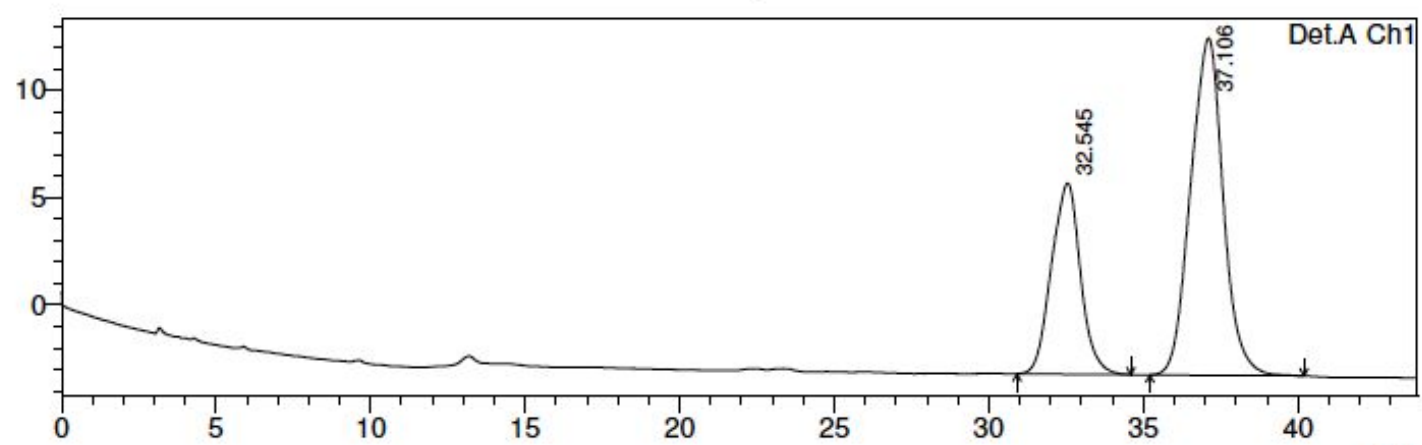

Detector A Ch1 254nm

\begin{tabular}{|r|r|r|r|}
\hline \multicolumn{1}{|c|}{ Peak\# } & \multicolumn{1}{|c|}{ Ret. Time } & \multicolumn{1}{c|}{ Area } & \multicolumn{1}{c|}{ Area \% } \\
\hline 1 & 32.545 & 582987 & 33.605 \\
\hline 2 & 37.106 & 1151817 & 66.395 \\
\hline Total & & 1734804 & 100.000 \\
\hline
\end{tabular}

Chiral HPLC analysis showed the presence of mixture of epimers in a 66/34 ratio

b) The amine was deprotected and coupled with commercial Fmoc-Alanine. The resulting product analyzed by NMR.

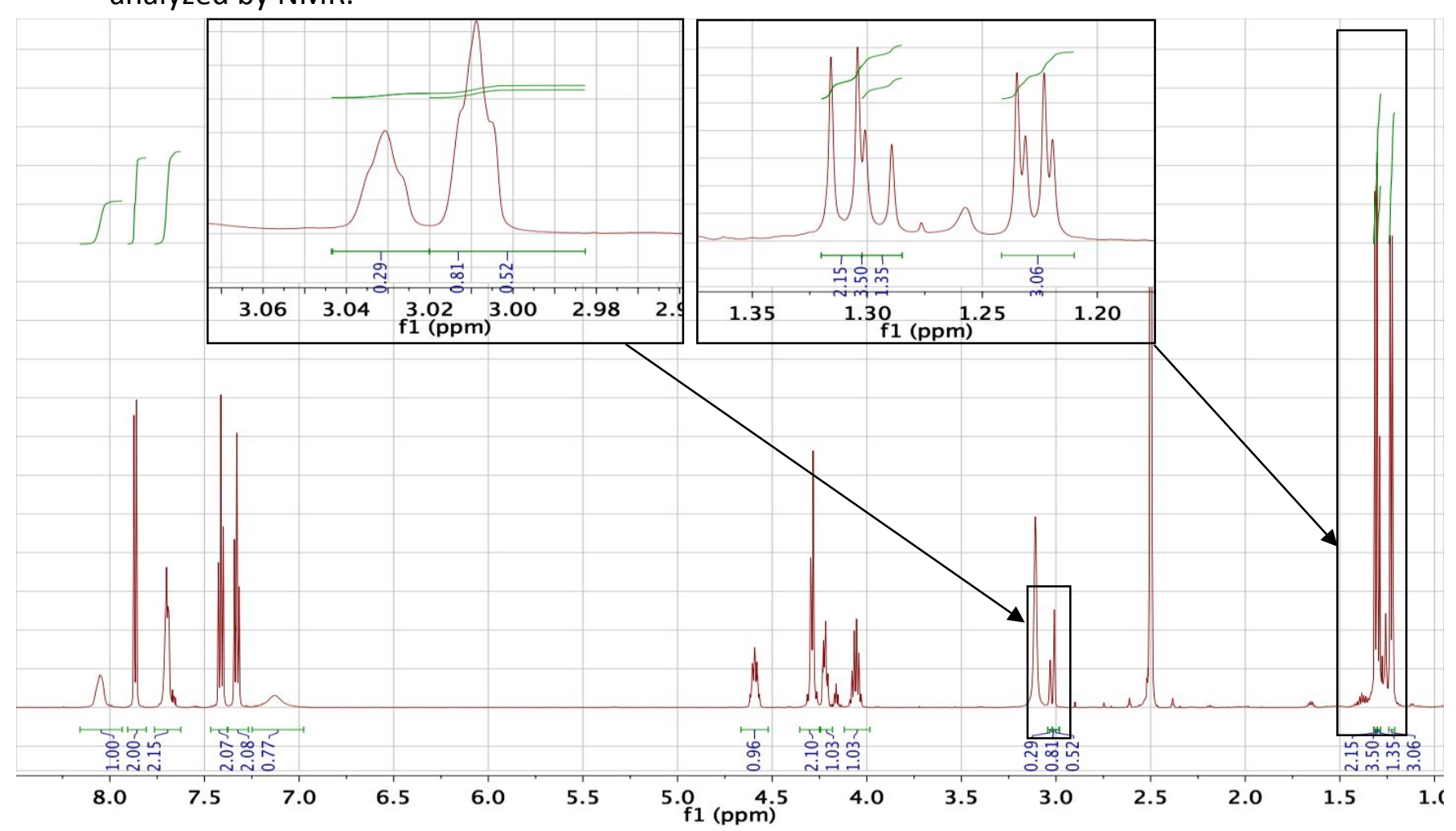

Acquisition at $600 \mathrm{MHz}$ at $65{ }^{\circ} \mathrm{C}$ in DMSO. The signals from the alkyne (at $3.25 \mathrm{ppm}$ ) and the methyl group (at $1.30 \mathrm{ppm}$ ) confirmed the presence of a mixture of diastereoisomers in an approximate 66/34 ratio. 
<smiles>C#CC(Cc1ccc(OCCC)cc1)NOCF</smiles>

The compound was synthesized as previously described. ${ }^{4}$ However, despite having followed the same conditions, we observed an partial racemization of the amino alkyne during the synthesis. This phenomenon was observed by two different methods.

a) Alkyne $\mathbf{9}$ was analyzed by chiral HPLC.

Conditions: Column Daicel Chiralpak IA, Hexane/iPrOH =95/5, $1.5 \mathrm{~mL} / \mathrm{min}$ at $301 \mathrm{~nm}$. $\mathrm{mV}$

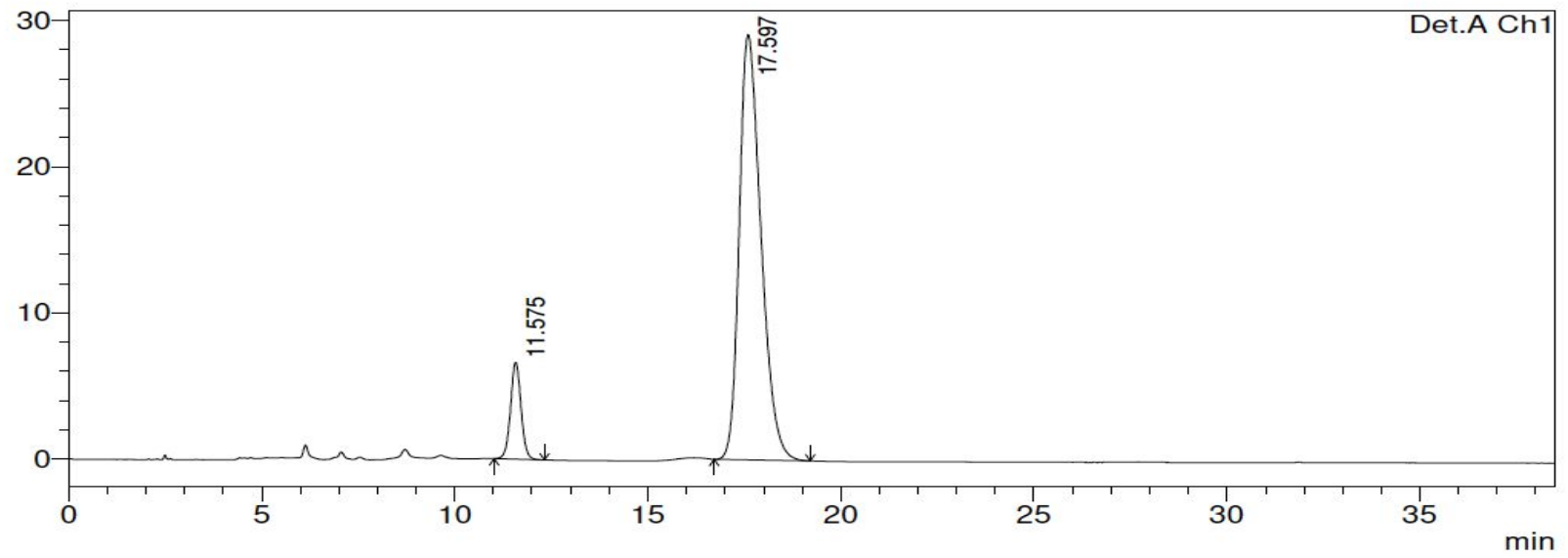

Detector A Ch1 301nm

\begin{tabular}{|r|r|r|r|r|}
\hline \multicolumn{1}{|c|}{ Peak\# } & Ret. Time & \multicolumn{1}{c|}{ Area } & \multicolumn{1}{c|}{ Height } & \multicolumn{1}{c|}{ Area \% } \\
\hline 1 & 11.575 & 126063 & 6635 & 9.942 \\
\hline 2 & 17.597 & 1141922 & 29108 & 90.058 \\
\hline Total & & 1267986 & 35742 & 100.000 \\
\hline
\end{tabular}

Chiral HPLC analysis showed the presence of mixture of epimers in a 90/10 ratio

b) The amine was deprotected and coupled with commercial Fmoc-Alanine. The resulting product was analyzed by NMR.

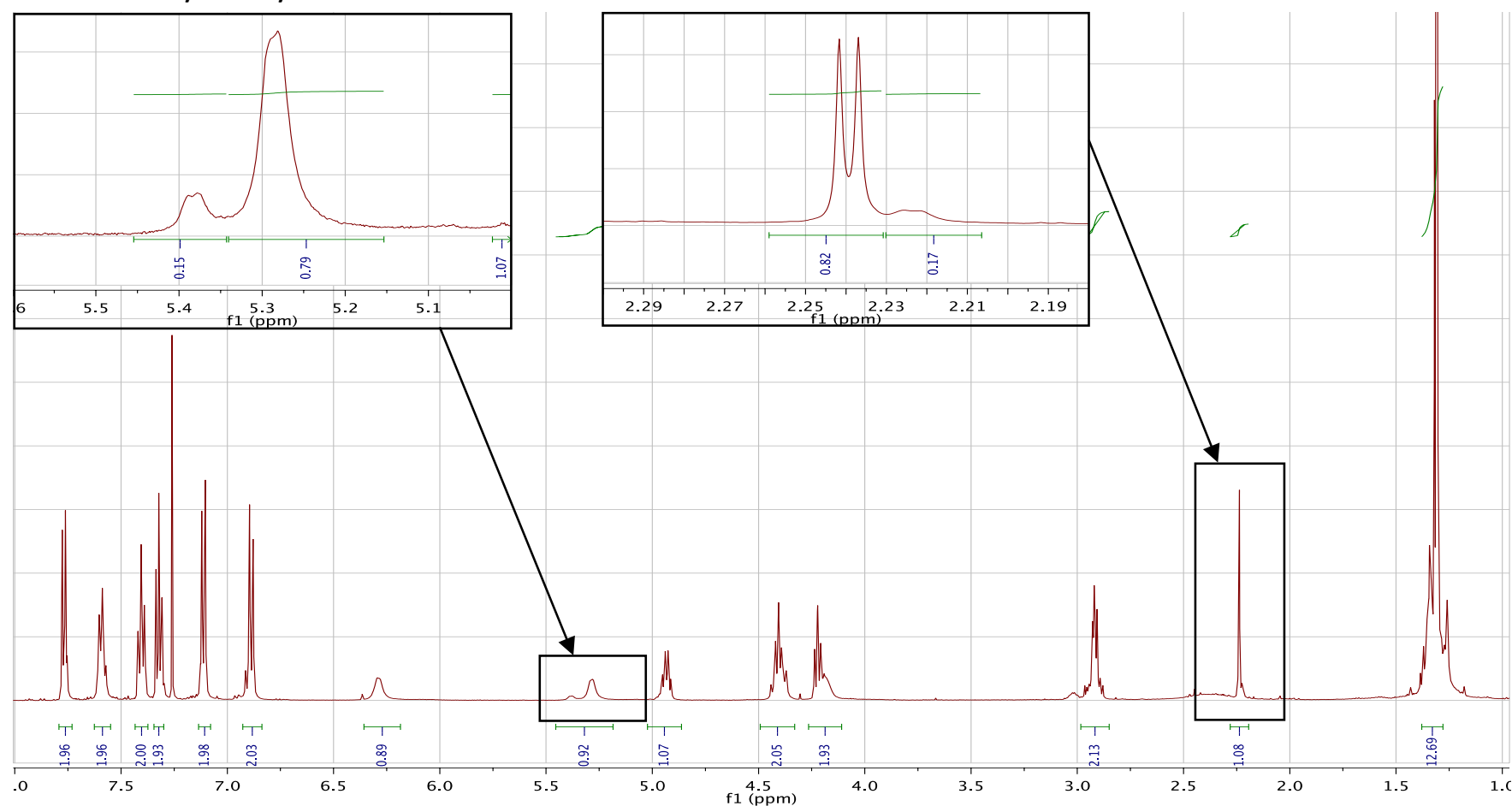

Acquisition at $500 \mathrm{MHz}$ at $25^{\circ} \mathrm{C}$ in $\mathrm{CDCl}_{3}$.

The signals from the alkyne (at $2.24 \mathrm{ppm}$ ) and the amide (at $5.30 \mathrm{ppm}$ ) confirmed the presence of a mixture of diastereoisomers in an approximate $83 / 17$ ratio. 


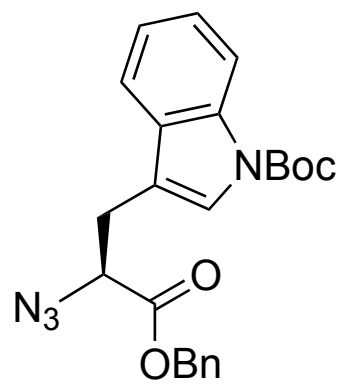

To a solution of Fmoc-Trp(Boc)-OH (1.5 g, 2.85 mmol, 1 equiv.) and DIEA (744 $\mu \mathrm{L}, 4.27$ mmol, 1.5 equiv.) in DMF $(20 \mathrm{~mL})$ at $\mathrm{RT}$ was added $\mathrm{BnBr}(745 \mu \mathrm{L}, 4.27 \mathrm{mmol}, 1.5$ equiv.), and the solution was allowed to stir overnight. The solution was then concentrated under vacuo, added EtOAc $(20 \mathrm{~mL})$, and poured into a separatory funnel containing ice-cold water $(100 \mathrm{~mL})$. The cold aqueous solution was extracted once with EtOAc $(20 \mathrm{~mL})$. The organic phases were pooled together, dried over $\mathrm{Na}_{2} \mathrm{SO}_{4}$, filtered, and the solvent was evaporated under vacuum. The crude mixture was purified $\left(\mathrm{SiO}_{2}\right.$ column chromatography Pentane/EtOAc (9:1) to (8:2)) to afford the benzyl ester (CAS n $\left.{ }^{\circ} 1170938-31-4\right) .{ }^{1} \mathbf{H} \mathbf{N M R}\left(500 \mathrm{MHz}, \mathrm{CDCl}_{3}\right) \delta 8.04(\mathrm{~d}, J=6.7$ $\mathrm{Hz}, 1 \mathrm{H}), 7.68(\mathrm{~d}, J=7.6 \mathrm{~Hz}, 2 \mathrm{H}), 7.48-7.43(\mathrm{~m}, 3 \mathrm{H}), 7.33-7.30(\mathrm{~m}, 3 \mathrm{H}), 7.27-7.19(\mathrm{~m}, 6 \mathrm{H}), 7.16-7.11(\mathrm{~m}$, $3 \mathrm{H}), 5.35(\mathrm{~d}, J=8.1 \mathrm{~Hz}, 1 \mathrm{H}), 5.03(\mathrm{dd}, J=12.2,31.5 \mathrm{~Hz}, 2 \mathrm{H}), 4.74(\mathrm{~m}, 1 \mathrm{H}), 4.33-4.25(\mathrm{~m}, 2 \mathrm{H}), 4.13(\mathrm{t}, J=7.3$ $\mathrm{Hz}, 1 \mathrm{H}), 3.19(\mathrm{~d}, J=5.9 \mathrm{~Hz}, 2 \mathrm{H}), 1.57(\mathrm{~s}, 9 \mathrm{H})$.

To a solution of Fmoc-Trp(Boc)-OBn (1.68 g, $2.72 \mathrm{mmol})$ in $\mathrm{CH}_{2} \mathrm{Cl}_{2}(20 \mathrm{~mL})$ at $0^{\circ} \mathrm{C}$ was added diethylamine (10 $\mathrm{mL}, 1500$ equiv.) and the reaction was allowed to stir at RT. The reaction was monitored by TLC (Pentane/EtOAc (9:1)). After $6 \mathrm{~h}$, the solvent and diethylamine were removed by evaporation under vacuo with the water bath at $0^{\circ} \mathrm{C}$. The crude mixture was purified by $\mathrm{SiO}_{2}$ column chromatography $\left(\mathrm{CH}_{2} \mathrm{Cl}_{2} / \mathrm{MeOH}\right.$ $100 \%$ to $95 \%$ ) to yield the free amine (CAS n $\left.{ }^{\circ} 1170940-54-1\right)$ in quantitative yield. ${ }^{1} \mathbf{H}$ NMR $\left(500 \mathrm{MHz} \mathrm{CDCl}_{3}\right)$ $\delta 8.13(\mathrm{~d}, J=6.1 \mathrm{~Hz}, 1 \mathrm{H}), 7.54(\mathrm{~m}, 1 \mathrm{H}), 7.45(\mathrm{br} \mathrm{s}, 1 \mathrm{H}), 7.34-7.30(\mathrm{~m}, 4 \mathrm{H}), 7.27-7.21(\mathrm{~m}, 3 \mathrm{H}), 5.12(\mathrm{dd}, J=$ $12.3,17.9 \mathrm{~Hz}, 2 \mathrm{H}$ ), $3.88(\mathrm{dd}, J=7.8,5.2 \mathrm{~Hz}, 1 \mathrm{H}$ ), $3.21(\mathrm{dd}, J=14.4,5.2 \mathrm{~Hz}, 1 \mathrm{H}), 3.00(\mathrm{dd}, J=14.4,7.8 \mathrm{~Hz}, 1 \mathrm{H}$ ), $1.66(\mathrm{~s}, 9 \mathrm{H})$.

To a solution of corresponding free amine (600 mg, $1.5 \mathrm{mmol}, 1$ equiv.) and DIEA (292 $\mu \mathrm{L}, 1.67 \mathrm{mmol}, 1.1$ equiv.) in DMF $(15 \mathrm{~mL}$ ) was added imidazole-1-sulfonyl azide dihydrochloride (349 mg, $1.67 \mathrm{mmol}, 1.1$ equiv.), and the solution was allowed to stir until the reaction was finished. The solvent was partially evaporated under vacuo, the mixture was added EtOAc $(20 \mathrm{~mL})$ and poured into a separatory funnel with ice-cold water $(100 \mathrm{~mL})$. The cold aqueous solution was extracted once with EtOAc $(20 \mathrm{~mL})$. The organic phases were dried over $\mathrm{MgSO}_{4}$, filtered and concentrated under reduced pressure. The residue was purified by flash chromatography on silica gel (Pentane/EtOAc (95:5)) to afford product $\mathbf{1 0}$ in 58\% yield over 3 steps.

${ }^{1} \mathrm{H}$ NMR $\left(500 \mathrm{MHz}, \mathrm{CDCl}_{3}\right): \delta 8.14(\mathrm{~d}, J=6.5 \mathrm{~Hz}, 1 \mathrm{H}), 7.56-7.51(\mathrm{~m}, 1 \mathrm{H}), 7.48(\mathrm{~s}, 1 \mathrm{H}), 7.36-7,31(\mathrm{~m}, 3 \mathrm{H}), 7.28$ $-7.21(\mathrm{~m}, 4 \mathrm{H}), 5.17(\mathrm{dd}, J=12.2,15.0 \mathrm{~Hz}, 2 \mathrm{H}), 4.23(\mathrm{dd}, J=8.3,5.7 \mathrm{~Hz}, 1 \mathrm{H}), 3.28(\mathrm{dd}, J=14.8,5.7 \mathrm{~Hz}, 1 \mathrm{H})$, $3.13(\mathrm{dd}, J=14.8,8.3 \mathrm{~Hz}, 1 \mathrm{H}), 1.67(\mathrm{~s}, 9 \mathrm{H})$.

${ }^{13} \mathrm{C}$ NMR $\left(126 \mathrm{MHz}, \mathrm{CDCl}_{3}\right.$ ): $\delta 170.0,149.7,135.6,135.0,130.1,128.8$ (2 C signals), 128.7, 128.5 (2 C signals), $124.8,124.6,122.8,118.8,115.6,114.9,83.9,67.8,62.0,28.4,27.5$.

ESI-HRMS : $[\mathrm{M}+\mathrm{Na}]^{+} \mathrm{m} / z=443.1690$ (calcd. for $\mathrm{C}_{23} \mathrm{H}_{24} \mathrm{~N}_{4} \mathrm{NaO}_{4}: 443.1695$ ).

$[\alpha]^{20}:-0,0215\left(\mathrm{c} 0.5, \mathrm{CHCl}_{3}\right)$

IR : 2104, 1730, 1152, 743, $696 \mathrm{~cm}^{-1}$ 
<smiles>CCCOc1ccc(C[C@H](N)C(=O)Oc2ccccc2)cc1</smiles>

To a solution of Fmoc-Tyr(tBu)-OH ( $2 \mathrm{~g}, 5 \mathrm{mmol}, 1$ equiv.) and DIEA (1.74 mL, $10 \mathrm{mmol}, 2$ equiv.) in DMF (40 $\mathrm{mL}$ ) at $\mathrm{RT}$ was added $\mathrm{BnBr}(1.74 \mu \mathrm{L}, 10 \mathrm{mmol}, 2$ equiv.), and the solution was allowed to stir overnight. The solution was then concentrated under vacuo, added EtOAc $(20 \mathrm{~mL})$, and poured into a separatory funnel containing ice-cold water $(100 \mathrm{~mL})$. The cold aqueous solution was extracted once with EtOAc $(20 \mathrm{~mL})$. The organic phases were pooled together, dried over $\mathrm{Na}_{2} \mathrm{SO}_{4}$, filtered, and the solvent was evaporated under vacuum. The crude mixture was purified $\left(\mathrm{SiO}_{2}\right.$ column chromatography $\mathrm{CH}_{2} \mathrm{Cl}_{2} / \mathrm{MeOH} 100 \%$ to $99.5 \%$ to afford the benzyl ester (CAS $n^{\circ}$ 203190-35-6). Identity was confirmed by comparison with the literature. ${ }^{6}$ To a solution of Fmoc-Tyr(tBu)-OBn $(1 \mathrm{~g}, 1.82 \mathrm{mmol})$ in DMF $(20 \mathrm{~mL})$ at $0^{\circ} \mathrm{C}$ was added diethylamine $(2 \mathrm{~mL})$, and the reaction was allowed to stir at RT. The reaction was monitored by $\operatorname{TLC}\left(\mathrm{CH}_{2} \mathrm{Cl}_{2} / \mathrm{MeOH}(97: 3)\right)$. After $1 \mathrm{~h}$, the solvent and the diethylamine were removed by evaporation under vacuo with the water bath at $0^{\circ} \mathrm{C}$. The crude mixture was purified by short pass $\mathrm{SiO}_{2}$ column chromatography $\mathrm{CH}_{2} \mathrm{Cl}_{2} / \mathrm{MeOH}$ 1:0 then 95:5) to yield the free amine (CAS $n^{\circ}$ 200936-28-3) in quantitative yield. Identity was confirmed by comparison with the literature. ${ }^{7}$

To a solution of corresponding free amine ( $280 \mathrm{mg}, 0.85 \mathrm{mmol}, 1$ equiv.) and DIEA (740 $\mu \mathrm{L}, 4.25 \mathrm{mmol}, 5$ equiv.) in DMF (15 mL) was added imidazole-1-sulfonyl azide dihydrosulfate (460 mg, $1.7 \mathrm{mmol}, 2$ equiv.), and the solution was allowed to stir until the reaction was finished. The solvent was evaporated, and the residue was redissolved in a $\mathrm{CH}_{2} \mathrm{Cl}_{2} / \mathrm{MeOH}$ mixture (1:1) and added silica. The residue was purified by flash chromatography on silica gel (Pentane/EtOAc (95:5)) to afford azide $\mathbf{1 1}$ in 50 \% yield over three steps.

${ }^{1} \mathrm{H}$ NMR $\left(500 \mathrm{MHz}, \mathrm{CDCl}_{3}\right): \delta 7.45-7.28(\mathrm{~m}, 5 \mathrm{H}), 7.08(\mathrm{~d}, J=8.4 \mathrm{~Hz}, 2 \mathrm{H}), 6.91(\mathrm{~d}, J=8.5 \mathrm{~Hz}, 2 \mathrm{H}), 5.19(\mathrm{~d}, J=$ $2.6 \mathrm{~Hz}, 2 \mathrm{H}), 4.06(\mathrm{dd}, J=8.4,5.7 \mathrm{~Hz}, 1 \mathrm{H}), 3.14(\mathrm{dd}, J=14.0,5.7 \mathrm{~Hz}, 1 \mathrm{H}), 2.99(\mathrm{dd}, J=14.0,8.4 \mathrm{~Hz}, 1 \mathrm{H}), 1.33$ $(\mathrm{s}, 9 \mathrm{H})$.

${ }^{13} \mathrm{C}$ NMR (126 MHz, CDCl $): \delta$ 169.9, 154.7, 135.0, 130.5, 129.7 (2 signals), 128.7 (2 signals), 128.6, 128.5 (2 signals), 124.3 (2 signals), 78.5, 67.5, 63.3, 37.1, 28.9.

ESI-HRMS : $[\mathrm{M}+\mathrm{Na}]^{+} m / z=376.1622$ (calcd. for $\mathrm{C}_{20} \mathrm{H}_{23} \mathrm{~N}_{3} \mathrm{NaO}_{3}: 376.1632$ ).

$[\alpha]^{25}$ : $-0,033$ (c 1.0, $\mathrm{CHCl}_{3}$ )

IR : 2104, 1740, 1158, 749, $696 \mathrm{~cm}^{-1}$ 
<smiles>[N]CC(=O)OBr</smiles>

To a mixture of bromo acetic acid ( $10 \mathrm{~g}, 0.07 \mathrm{~mol}, 1$ equiv.) in toluene $(50 \mathrm{~mL})$ was added $p$-toluenesulfonic acid ( $250 \mathrm{mg}, 1.44 \mathrm{mmol}, 0.02$ equiv.) and benzyl alcohol ( $6.5 \mathrm{~mL}, 0.063 \mathrm{~mol}, 0.9$ equiv.), and the mixture was refluxed overnight. The mixture was concentrated under vacuo, was added $\mathrm{CH}_{2} \mathrm{Cl}_{2}(100 \mathrm{~mL})$ and an aqueous solution of sat. $\mathrm{NaHCO}_{3}(100 \mathrm{~mL})$, and the aqueous phase was extracted two times with $\mathrm{CH}_{2} \mathrm{Cl}_{2}(50$ $\mathrm{mL}$ ). The organic phases were pooled together, dried over $\mathrm{Na}_{2} \mathrm{SO}_{4}$, filtered, and the solvent was evaporated. The residue was then purified by short pass silica gel column chromatography (Pentane/EtOAc: $95: 5$ ) to afford benzyl 2-bromo acetate in quantitative yield.

To a solution of benzyl 2-bromo acetate $(1.58 \mathrm{~g}, 10 \mathrm{mmol})$ in dry DMF $(15 \mathrm{~mL})$ was added sodium azide $(2.60$ $\mathrm{g}, 40 \mathrm{mmol}$ ), and the mixture was allowed to stir 3 days at RT. The mixture was then concentrated under vacuo and was added ethyl acetate $(50 \mathrm{~mL})$. The mixture was immediately placed in a separatory funnel containing ice-cold water $(50 \mathrm{~mL})$ and the organic phase was washed once with ice-cold water $(50 \mathrm{~mL})$. The organic phases were pooled together, dried over $\mathrm{Na}_{2} \mathrm{SO}_{4}$, filtered, and the filtrate was evaporated to dryness. The residue was then purified by silica gel chromatography (Pentane $/ \mathrm{CH}_{2} \mathrm{Cl}_{2}$ : gradient from (1:0) to (0:1)) to afford the desired compound in $84 \%$ yield.

${ }^{1} \mathrm{H}$ NMR $\left(500 \mathrm{MHz}, \mathrm{CDCl}_{3}\right): \delta 7.41-7.35(\mathrm{~m}, 5 \mathrm{H}), 5.23(\mathrm{~s}, 2 \mathrm{H}), 3.91(\mathrm{~s}, 2 \mathrm{H})$.

${ }^{13} \mathrm{C}$ NMR (126 MHz, CDCl 3 ): $\delta$ 168.2, 134.9 (1 signal), 128.7 (3 signals), 128.6 (2 signals), 67.6, 50.4.

The spectroscopic signals were found to be identical to those found in the literature. ${ }^{8}$ 


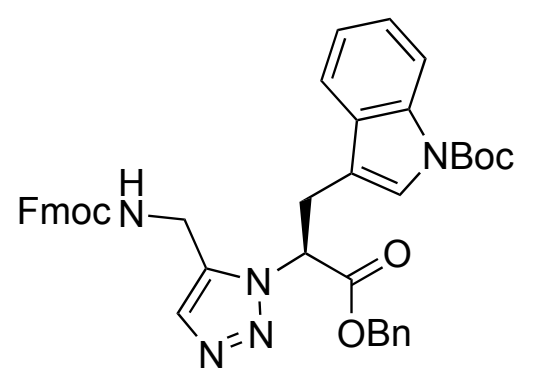

To a degassed solution of $\mathrm{Cp} * \mathrm{RuCl}\left(\mathrm{PPh}_{3}\right)_{2}(10 \mathrm{mg}, 0.012 \mathrm{mmol}, 0.05$ equiv) under Ar in dry DMF (300 $\mu \mathrm{L})$ was added a degassed solution of Fmoc-propargylamine ( $66 \mathrm{mg}, 0.24 \mathrm{mmol}, 1$ equiv) and azide 10 (100 mg, 0.24 mmol, 1 equiv) in dry DMF and toluene (5:2) (700 $\mu \mathrm{L})$. The vial was purged with $\operatorname{Ar}(3$ times). The suspension was then allowed to react at $65^{\circ}$ and monitored by RP-HPLC-MS.* After completion of the reaction, the solvent was completely evaporated. The residue was added $\mathrm{CH}_{2} \mathrm{Cl}_{2}$, chromatography-grade silica, and the solvent was removed under vacuo. The dry residue was used for a solid deposition in a silica gel column chromatography (Pentane/EtOAc (8:2)). The purification afforded the target compound 13 in $60 \%$ yield.

${ }^{1} \mathrm{H}$ NMR $\left(500 \mathrm{MHz}, \mathrm{CDCl}_{3}\right): \delta 8.08(\mathrm{~d}, J=8.3 \mathrm{~Hz}, 1 \mathrm{H}), 7.75(\mathrm{~d}, J=7.7 \mathrm{~Hz}, 2 \mathrm{H}), 7.50-7.38(\mathrm{~m}, 6 \mathrm{H}), 7.30-7.26$ $(\mathrm{m}, 6 \mathrm{H}), 7.22-7.19(\mathrm{~m}, 2 \mathrm{H}), 7.16-7.14(\mathrm{~m}, 2 \mathrm{H}), 5.63(\mathrm{br} \mathrm{s}, 1 \mathrm{H}), 5.13(\mathrm{dd}, J=12.3,15.1 \mathrm{~Hz}, 2 \mathrm{H}), 4.72(\mathrm{br} \mathrm{s}$, $1 \mathrm{H}), 4.28(\mathrm{~d}, J=6.9,2 \mathrm{H}), 4.17-4.09(\mathrm{~m}, 3 \mathrm{H}), 3.85(\mathrm{~d}, J=7.5 \mathrm{~Hz}, 2 \mathrm{H}), 1.60(\mathrm{~s}, 9 \mathrm{H})$.

${ }^{13} \mathrm{C}$ NMR $\left(151 \mathrm{MHz}, \mathrm{CDCl}_{3}\right): \delta 167.9,156.1,149.5,143.7,141.5,135.5,134.7,133.6,129.6,128.80,128.75$, $128.2,127.9,127.2,125.1,124.88,124.86,123.0,120.2,118.5,115.6,114.6,84.0,68.2,67.3,60.9,47.2$, $33.4,28.3,27.2$.

ESI-HRMS : $[\mathrm{M}+\mathrm{H}]^{+} m / z=698.2985$ (calcd. for $\mathrm{C}_{41} \mathrm{H}_{40} \mathrm{~N}_{5} \mathrm{O}_{6}: 698.2973$ ).

* This cycloaddition was particularly challenging. The reaction was left to stir for 8 hrs without monitoring then was added some additional catalyst (always followed by purge of the Schlenk flask with Ar) if the reaction was not completed. The operation was repeated until reaction completion. 
<smiles>CCCCOc1ccc(C[C@H](C(=O)OCc2ccccc2)n2nncc2C(C)NOC(F)F)cc1</smiles>

To a degassed solution of $\mathrm{Cp} * \mathrm{RuCl}\left(\mathrm{PPh}_{3}\right)_{2}(5 \mathrm{mg}, 5 \mu \mathrm{mol}, 0.02$ equiv) under Ar in dry DMF (300 $\mu \mathrm{L})$ was added degassed a solution of alkyne 8 ( $65 \mathrm{mg}, 0.24 \mathrm{mmol}, 1$ equiv) and azide 11 (79 mg, 0.24 mmol, 1 equiv) in dry DMF and toluene (5:2) (700 $\mu \mathrm{L}$ ). The Schlenk flask was purged with Ar ( 3 times). The suspension was then allowed to react at $65^{\circ}$ and monitored by RP-HPLC-MS. After completion of the reaction (usually after 2 to 3 hrs), the solvent was completely evaporated and the residue was added $\mathrm{CH}_{2} \mathrm{Cl}_{2}$, chromatography-grade silica, and the solvent was removed. The dry residue was used for a solid deposition in a silica gel column chromatography (Pentane/EtOAc (7:3)). The purification afforded the target compound $\mathbf{1 4}$ in $20 \%$ yield.

Due to the fact that the alkyne was not enantiomerically pure, the cycloaddition product was obtained as a mixture of diastereoisomers in nearly 6:4 ratio ( $M$ and $m$, respectively), see synthesis of compound 8 . Diastereoisomers could be distinguished by NMR but not by RP-HPLC in our standard conditions.

${ }^{1} \mathrm{H}$ NMR $\left(500 \mathrm{MHz}, \mathrm{CDCl}_{3}\right): \delta$ 7.77-7.75 (m, 2H), $7.56(\mathrm{~d}, J=7.4 \mathrm{~Hz}, 0.8 \mathrm{H}), 7.49(\mathrm{~d}, J=7.4 \mathrm{~Hz}, 1.2 \mathrm{H}), 7.45(\mathrm{~s}$, $0.4 \mathrm{H}), 7.42$ - $7.37(\mathrm{~m}, 2.6), 7.35-7.25(\mathrm{~m}, 3.4 \mathrm{H}), 7.21-7.18(\mathrm{~m}, 2.4 \mathrm{H}), 7.09$ (br s, $1.2 \mathrm{H}), 6.86-6.79(\mathrm{~m}, 3.2$ H), $6.61(\mathrm{~d}, J=6.6 \mathrm{~Hz}, 0.8 \mathrm{H}$ ), $5.45-5.42(\mathrm{~m}, 0.6 \mathrm{H}), 5.34(\mathrm{br} \mathrm{s}, 0.4 \mathrm{H}), 5.15(\mathrm{dd}, J=12.5,14.5 \mathrm{~Hz}, 0.8 \mathrm{H}), 5.05$ (dd, $J=12.5,18.5 \mathrm{~Hz}, 1.2 \mathrm{H}$ ), $4.85(\mathrm{br} \mathrm{s}, 0.4 \mathrm{H}), 4.75(\mathrm{br} \mathrm{d}, J=8.0 \mathrm{~Hz}, 0.6 \mathrm{~Hz}), 4.55(\mathrm{dd}, J=6.1,10.8 \mathrm{~Hz}, 0.4 \mathrm{H}$ ), $4.49(\mathrm{dd}, J=6.1,10.8 \mathrm{~Hz}, 0.4 \mathrm{H}), 4.38(\mathrm{dd}, J=6.8,10.6 \mathrm{~Hz}, 1.2 \mathrm{H}), 4.25-4.18(\mathrm{~m}, 1.4 \mathrm{H}), 4.09(\mathrm{t}, J=6.7 \mathrm{~Hz}$, $0.6 \mathrm{H}), 3.74-3.683(\mathrm{~m}, 0.4 \mathrm{H}), 3.64-3.58(\mathrm{~m}, 1.6 \mathrm{H}), 1.35(\mathrm{br} \mathrm{s}, 1.2 \mathrm{H}), 1.27(\mathrm{~s}, 6.1 \mathrm{H}), 1.22-1.20(\mathrm{~m}, 4.7 \mathrm{H})$.

${ }^{13} \mathrm{C}$ NMR (151 MHz, CDCl 3$): \delta 167.73(\mathrm{M}), 167.70(\mathrm{~m}), 155.5(\mathrm{M}+\mathrm{m}), 154.7(\mathrm{M}), 154.4(\mathrm{~m}), 143.8(\mathrm{~m}), 143.7$ (M), $141.6(\mathrm{~m}), 141.48(\mathrm{M}), 141.45(\mathrm{M}), 134.96(\mathrm{M}), 134.90(\mathrm{~m}), 130.8(\mathrm{M}), 130.6(\mathrm{~m}), 129.9(\mathrm{M}), 129.6(\mathrm{~m})$, $128.79(\mathrm{M}), 128.71(\mathrm{~m}), 128.66(\mathrm{M}), 128.49(\mathrm{~m}), 128.20(\mathrm{M}), 128.00,127.97,127.96,127.3(\mathrm{~m}), 127.2(\mathrm{M})$, $125.1(\mathrm{M}), 124.9(\mathrm{~m}), 124.5(\mathrm{M}), 124.3(\mathrm{~m}), 120.3(\mathrm{~m}), 120.21(\mathrm{~m}), 120.19(\mathrm{M}), 78.56(\mathrm{M}), 78.51(\mathrm{~m}), 68.0$ (M), $67.9(\mathrm{~m}), 67.1(\mathrm{~m}), 66.6(\mathrm{M}), 62.4(\mathrm{M}), 61.8(\mathrm{~m}), 47.5(\mathrm{M}), 47.3(\mathrm{~m}), 40.1^{*}(\mathrm{~m}), 39.7(\mathrm{M}), 37.4(\mathrm{~m}), 36.1$ (M), $28.93(\mathrm{M}), 28.91(\mathrm{~m}), 20.3(\mathrm{~m}), 20.1(\mathrm{M})$.

ESI-HRMS : $[\mathrm{M}+\mathrm{H}]^{+} m / z=645.3077$ (calcd. for $\mathrm{C}_{39} \mathrm{H}_{41} \mathrm{~N}_{4} \mathrm{O}_{5}: 645.3072$ ).

\footnotetext{
* Found by HSQC
} 
<smiles>CCCCOc1ccc(CC(NOC(F)(F)F)c2cnnn2CC(=O)Oc2ccccc2)cc1</smiles>

To a degassed solution of $\mathrm{Cp} * \mathrm{RuCl}\left(\mathrm{PPh}_{3}\right)_{2}(5 \mathrm{mg}, 5 \mu \mathrm{mol}, 0.02$ equiv) under Ar in dry DMF (300 $\mu \mathrm{L})$ was added degassed a solution of alkyne 9 ( $100 \mathrm{mg}, 0.24 \mathrm{mmol}, 1.1$ equiv) and azide 12 (38,2 mg, 0.24 mmol, 1 equiv) in dry DMF and toluene (5:2) (700 $\mu \mathrm{L}$ ). The Schlenk flask was purged with $\operatorname{Ar}$ ( 3 times). The suspension was then allowed to react at $65^{\circ} \mathrm{C}$ and monitored by RP-HPLC-MS. After completion of the reaction (usually after 1 to $2 \mathrm{hrs}$ ), the solvent was completely evaporated, and the residue was added $\mathrm{CH}_{2} \mathrm{Cl}_{2}$, chromatographygrade silica, and the solvent was removed. The dry residue was used for a solid deposition in a silica gel column chromatography (Pentane/EtOAc (7:3) to (6:4)). The purification afforded the target compound 15 in $72 \%$ yield.

${ }^{1} \mathrm{H}$ NMR $\left(500 \mathrm{MHz}, \mathrm{CDCl}_{3}\right): \delta 7.72(\mathrm{~d}, J=7.6 \mathrm{~Hz}, 2 \mathrm{H}), 7.59(\mathrm{br} \mathrm{s}, 1 \mathrm{H}), 7.48-7.39(\mathrm{~m}, 2 \mathrm{H}), 7.37(\mathrm{dt}, J=7.5,2.8$ $\mathrm{Hz}, 2 \mathrm{H}), 7.32-7.22(\mathrm{~m}, 7 \mathrm{H}), 6.99(\mathrm{~s}, 2 \mathrm{H}), 6.86(\mathrm{~d}, J=7.8 \mathrm{~Hz}, 2 \mathrm{H}), 5.35-4.81(\mathrm{~m}, 6 \mathrm{H}), 4.31(\mathrm{br} \mathrm{s}, 1 \mathrm{H}), 4.21(\mathrm{br}$ $\mathrm{s}, 1 \mathrm{H}), 4.05(\mathrm{t}, J=6.6 \mathrm{~Hz}, 1 \mathrm{H}), 3.16(\mathrm{br} \mathrm{s}, 1 \mathrm{H}), 3.02(\mathrm{br} \mathrm{s}, 1 \mathrm{H}), 1.27(\mathrm{~s}, 9 \mathrm{H})$.

${ }^{13} \mathrm{C}$ NMR $\left(151 \mathrm{MHz}, \mathrm{CDCl}_{3}\right): \delta 166.6,154.7,143.7,143.5,141.4,134.7,129.8,128.8,128.5,127.9,127.9$, $127.2,125.0,124.4,120.1,78.6,68.0,67.0,47.2,46.6,39.8,29.8,28.9$.

ESI-HRMS : $[\mathrm{M}+\mathrm{H}]^{+} m / z=631.2915$ (calcd. for $\mathrm{C}_{38} \mathrm{H}_{39} \mathrm{~N}_{4} \mathrm{O}_{5}: 631.2920$ ). 


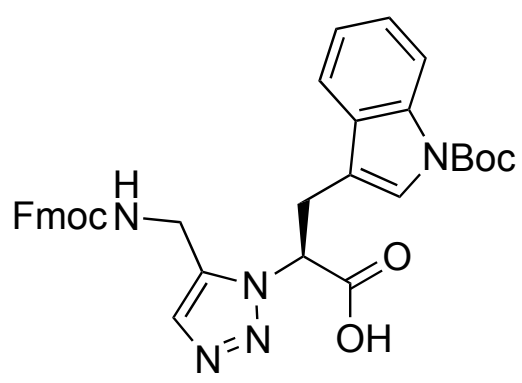

To a degassed solution of compound 13 (100 mg, $0.16 \mathrm{mmol}$ ) in EtOH $(5 \mathrm{~mL})$ was added Pd on charcoal 10\% (approx. $20 \mathrm{mg}$ ), and the solution was put under vacuo then under $\mathrm{H}_{2}$ atmosphere. The solution was allowed to stir 4 hours then the suspension was filtered over dicalite. The filtrate was evaporated and purified by silica gel column chromatography $\mathrm{CH}_{2} \mathrm{Cl}_{2}$ pure to $\mathrm{CH}_{2} \mathrm{Cl}_{2} / \mathrm{EtOH}(5: 5)$. The fractions were pooled together and evaporated, the residue was dissolved in $\mathrm{MeOH}$ and filtered to afford the target compound quantitatively.

${ }^{1} \mathrm{H}$ NMR $\left(500 \mathrm{MHz}, \mathrm{CD}_{3} \mathrm{OD}\right): \delta 7.96(\mathrm{~d}, J=5.7 \mathrm{~Hz}, 1 \mathrm{H}), 7.73(\mathrm{~d}, J=7.5 \mathrm{~Hz}, 2 \mathrm{H}), 7.55-7.49(\mathrm{~m}, 3 \mathrm{H}), 7.46(\mathrm{~s}, 1 \mathrm{H})$, $7.32(\mathrm{t}, J=7.0 \mathrm{~Hz}, 2 \mathrm{H}), 7.22-7.07(\mathrm{~m}, 5 \mathrm{H}), 5.45(\mathrm{~d}, J=7.9 \mathrm{~Hz}, 1 \mathrm{H}), 4.23-4.14(\mathrm{~m}, 4 \mathrm{H}), 4.05-4.02(\mathrm{~m}, 1 \mathrm{H})$, $3.84(\mathrm{br} \mathrm{d}, J=14.1 \mathrm{~Hz}, 1 \mathrm{H}), 3.75-3.69(\mathrm{~m}, 1 \mathrm{H}), 1.53(\mathrm{~s}, 9 \mathrm{H})$ * $^{*}$

${ }^{13} \mathrm{C}$ NMR (151 MHz, CD $\left.\mathrm{OD}\right): \delta$ 174.9**, 158.4, 150.8, 145.2, 142.5, 138.2, 136.6, 133.6, 131.5, 128.7, 128.1, $126.2,125.4,125.0,123.6,120.9,119.8,117.9,116.1,84.6,68.0,65.1,48.3^{* *}, 34.7,28.34,28.25$.

ESI-HRMS : $[\mathrm{M}+\mathrm{H}]^{+} \mathrm{m} / z=608.2503$ (calcd. for $\mathrm{C}_{34} \mathrm{H}_{34} \mathrm{~N}_{5} \mathrm{O}_{6}: 608.2504$ ).

* The proton of the free carboxylic acid could not be observed due to its exchange with the solvent.

** Observed by HSQC, HMBC, and/or ${ }^{13} \mathrm{C}$ (at $600 \mathrm{MHz}$ with 8k scans), see NMR spectra. 
<smiles>CCCCOc1ccc(C[C@H](C(=O)O)n2nncc2C(C)NOC(F)F)cc1</smiles>

To a degassed solution of compound 14 (100 mg, $0.18 \mathrm{mmol}$ ) in EtOH $(5 \mathrm{~mL}$ ) was added Pd on charcoal 10\% (approx. $20 \mathrm{mg}$ ), and the solution was put under vacuum then under $\mathrm{H}_{2}$ atmosphere. The solution was allowed to stir 4 hours then the suspension was filtered over dicalite to afford the target compound quantitatively.

Due to the fact that the starting material was not enantiomerically pure, the product was obtained as a mixture of diastereoisomers in nearly 6:4 ratio (NMR).

${ }^{1} \mathrm{H}$ NMR $\left(500 \mathrm{MHz}, \mathrm{CDCl}_{3}\right): \delta 9.22(\mathrm{br} \mathrm{s}, 1 \mathrm{H}), 7.76-7.75(\mathrm{~m}, 1 \mathrm{H}), 7.68-7.67(\mathrm{~m}, 1 \mathrm{H}), 7.61-7.59(\mathrm{~m}, 0.6 \mathrm{H})$, $7.51-7.45(\mathrm{~m}, 1.4 \mathrm{H}), 7.41-7.38(\mathrm{~m}, 1 \mathrm{H}), 7.36-7.22(\mathrm{~m}, 5 \mathrm{H}), 6.81-6.78(\mathrm{~m}, 3.4 \mathrm{H}), 6.56-6.54(\mathrm{~m}, 0.6 \mathrm{H})$, $5.42-5.34(\mathrm{~m}, 1 \mathrm{H}), 5.01-4.89(\mathrm{~m}, 0.6 \mathrm{H}), 4.51-4.12(\mathrm{~m}, 3.4 \mathrm{H}), 3.73-3.52(\mathrm{~m}, 2 \mathrm{H}), 1.39-1.11(\mathrm{~m}, 12 \mathrm{H})$.

${ }^{13} \mathrm{C}$ NMR $\left(126 \mathrm{MHz}, \mathrm{CDCl}_{3}\right): \delta$ 169.6, 156.1, 154.6, 143.9, 143.7, 143.5, 141.5, 141.4, 141.3, 130.9, 129.8, 129.6, 128.01, 127.97, 127.90, 127.3, 125.3, 125.1, 124.98, 124.50, 124.3, 120.2, 120.1, 78.7, 67.3, 62.5, 47.4, $47.2,40.2,37.5,35.9,28.90,28.86,20.1,19.9$.

ESI-HRMS : $[\mathrm{M}+\mathrm{H}]^{+} \mathrm{m} / \mathrm{z}=555.2598$ (calcd. for $\mathrm{C}_{32} \mathrm{H}_{35} \mathrm{~N}_{4} \mathrm{O}_{5}: 555.2602$ ). 
<smiles>CCCCOc1ccc(CC(NOC(F)(F)F)c2cnnn2CC(=O)O)cc1</smiles>

To a degassed solution of compound 15 (100 mg, $0.18 \mathrm{mmol}$ ) in EtOH $(5 \mathrm{~mL}$ ) was added Pd on charcoal 10\% (approx. $20 \mathrm{mg}$ ), and the solution was put under vacuum then under $\mathrm{H}_{2}$ atmosphere. The solution was allowed to stir $30 \mathrm{~min}$ then the suspension was filtered over dicalite. The filtrate was dried, and the residue was purified by silica gel chromatography $\left(\mathrm{CH}_{2} \mathrm{Cl}_{2}\right.$ then $\left.\mathrm{EtOH}\right)$. The compound was obtained as a mixture of enantiomers in $90 \%$ yield.

${ }^{1} \mathrm{H}$ NMR (500 MHz, CD $\mathrm{OD}$ ): $\delta 7.76(\mathrm{~d}, J=7.6 \mathrm{~Hz}, 2 \mathrm{H}), 7.71(\mathrm{~s}, 1 \mathrm{H}), 7.54(\mathrm{dd}, J=10.6,7.9 \mathrm{~Hz}, 2 \mathrm{H}), 7.37(\mathrm{t}, J=$ $7.5 \mathrm{~Hz}, 2 \mathrm{H}), 7.32-7.23(\mathrm{~m}, 2 \mathrm{H}), 7.18(\mathrm{~d}, J=8.0 \mathrm{~Hz}, 2 \mathrm{H}), 6.82(\mathrm{~d}, J=8.2 \mathrm{~Hz}, 2 \mathrm{H}), 5.03(\mathrm{~s}, 3 \mathrm{H}), 4.23(\mathrm{dd}, J=10.3$, $7.0 \mathrm{~Hz}, 1 \mathrm{H}), 4.18-4.10(\mathrm{~m}, 1 \mathrm{H}), 4.05(\mathrm{t}, J=6.8 \mathrm{~Hz}, 1 \mathrm{H}), 3.22(\mathrm{dd}, J=3.5,14.0 \mathrm{~Hz}, 1 \mathrm{H}), 3.06(\mathrm{dd}, J=11.0,13.0$ $\mathrm{Hz}, 1 \mathrm{H}), 1.18$ (s, 9H).

${ }^{13}$ C NMR (126 MHz, CD $\left.\mathrm{OD}\right):$ : 168.6, 155.3, 145.3, 145.1, $142.5,140.8,{ }^{*} 139.9,133.9, * 132.1, * 131.0,128.7$, $128.1,126.2,125.1,120.9,79.5,67.9,51.6, * 48.2, * 48.1, * 40.3,29.1$.

ESI-HRMS : $[\mathrm{M}+\mathrm{H}]^{+} \mathrm{m} / \mathrm{z}=541.2437$ (calcd. for $\mathrm{C}_{31} \mathrm{H}_{33} \mathrm{~N}_{4} \mathrm{O}_{5}: 541.2446$ ). 


\section{NMR Spectra}

${ }^{1} \mathrm{H}$ spectrum of $10, \mathrm{~N}_{3} \operatorname{Trp}(\mathrm{Boc})-\mathrm{OBn}$

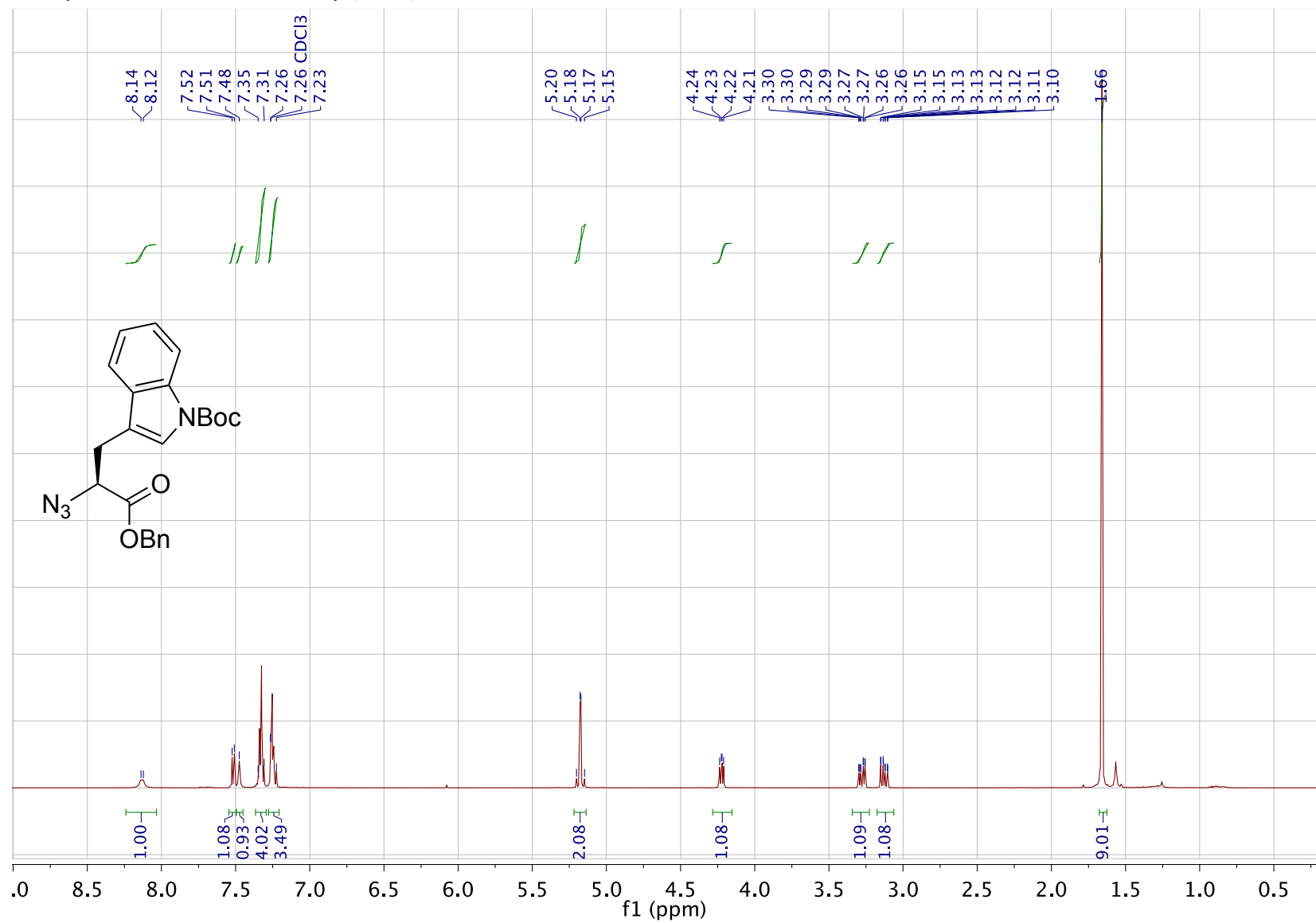

${ }^{13} \mathrm{C}$ spectrum of $\mathbf{1 0}$

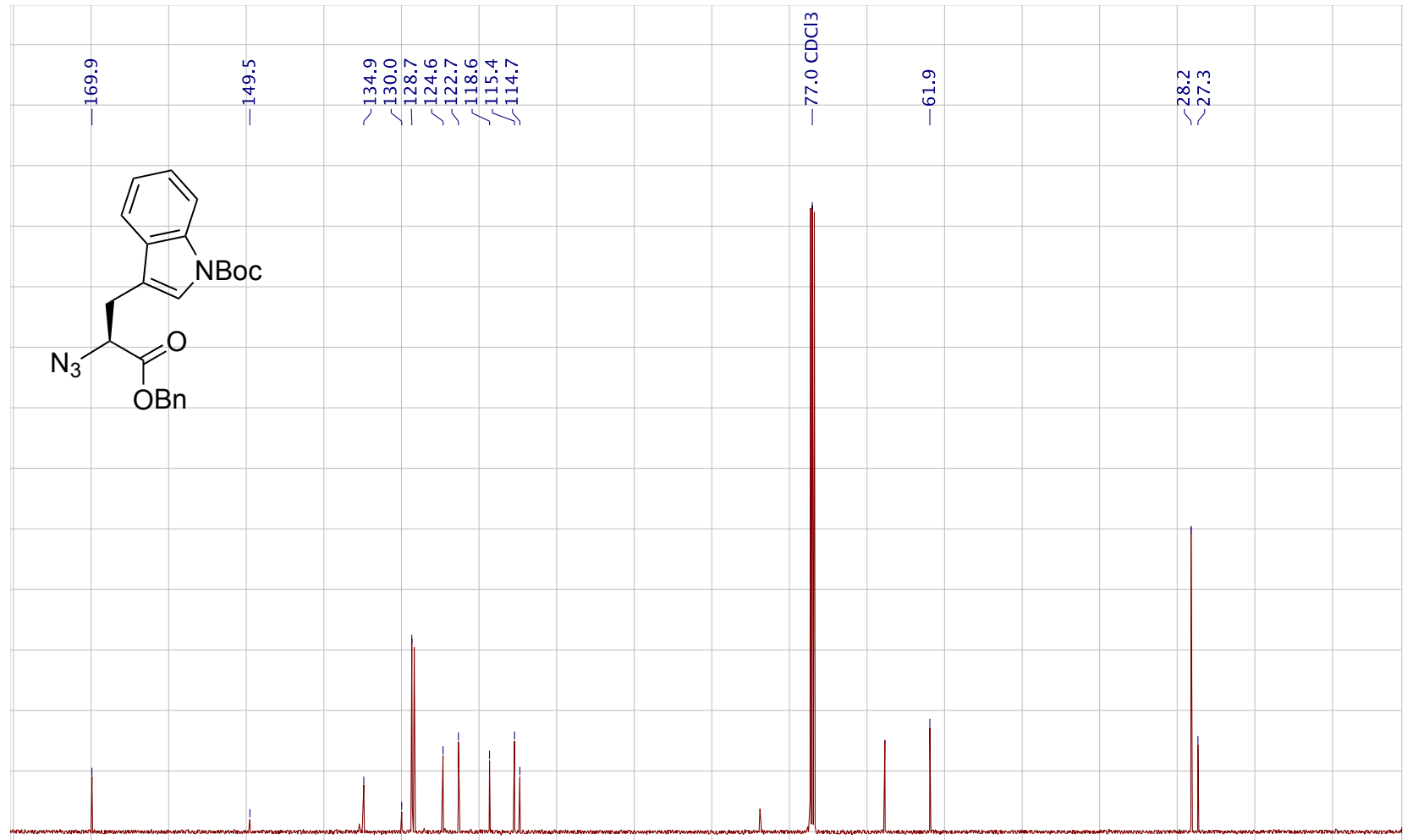

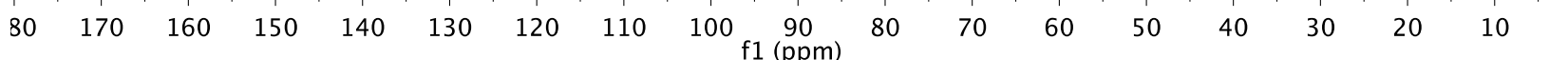


${ }^{1} \mathrm{H}$ spectrum of $11, \mathrm{~N}_{3} \operatorname{Tyr}(\mathrm{tBu})-\mathrm{OBn}$

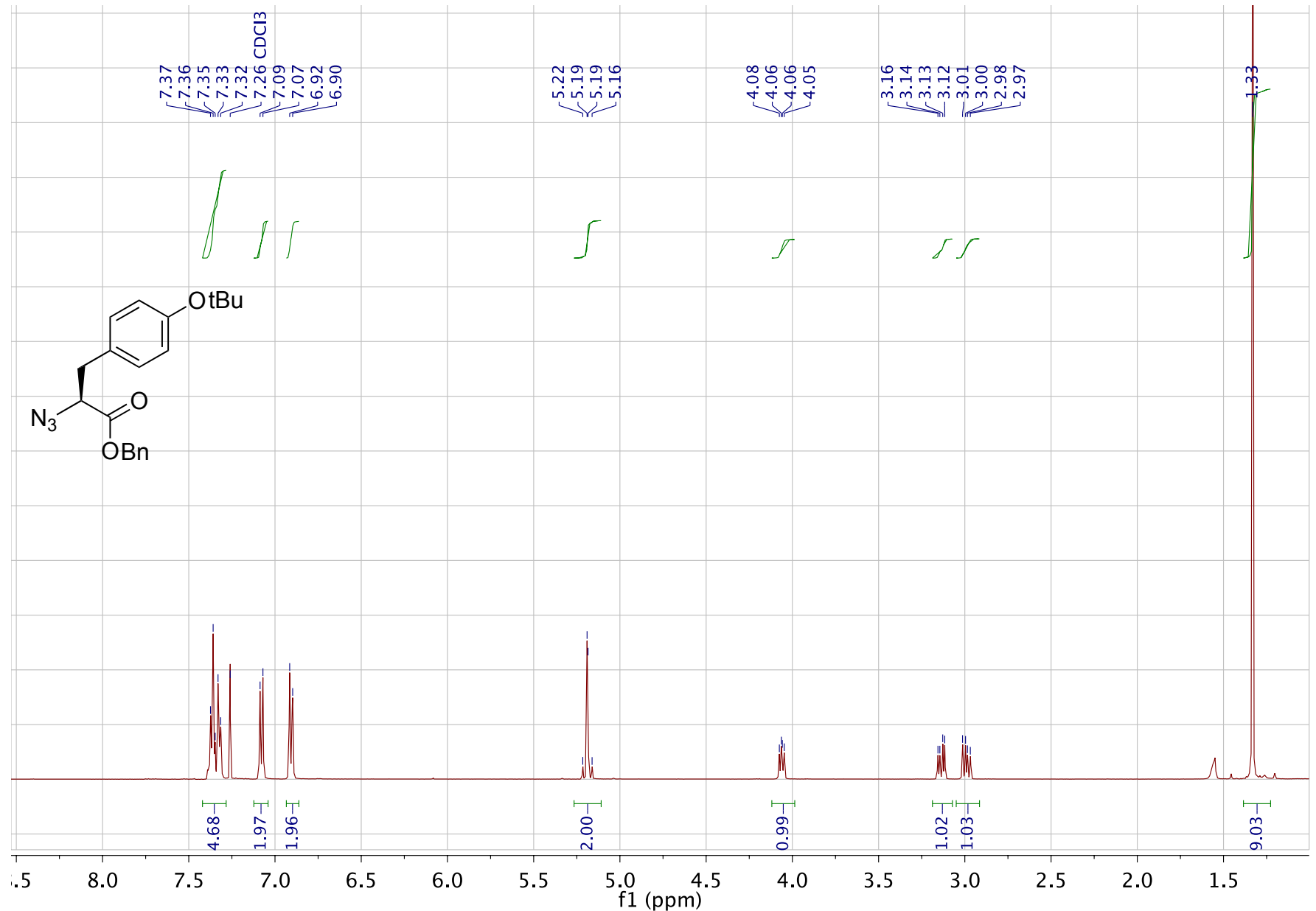

${ }^{13} \mathrm{C}$ spectrum of $\mathbf{1 1}$

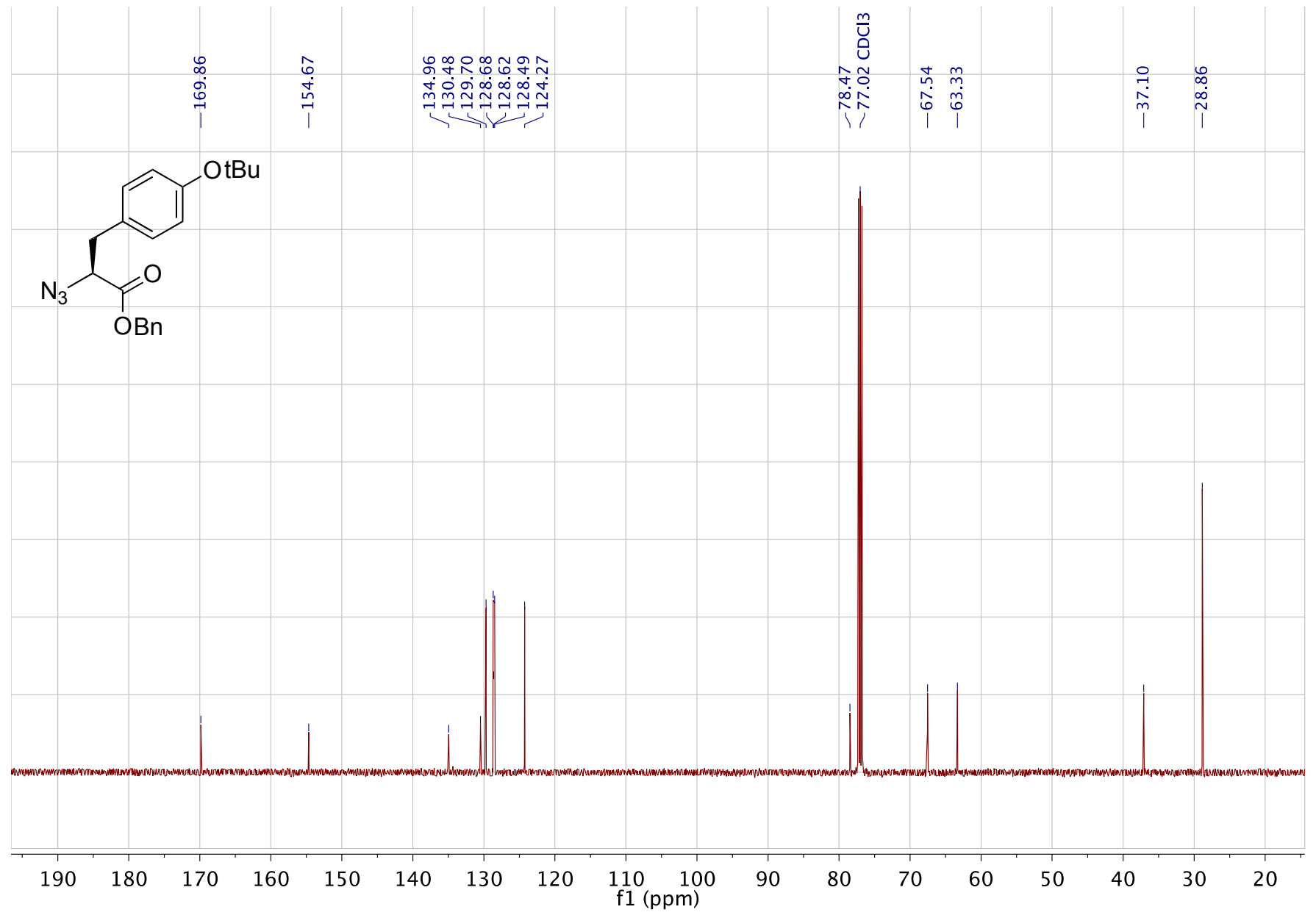


${ }^{1} \mathrm{H}$ spectrum of 13 , Fmoc-Gly $\left.\Psi^{11,5} \mathrm{Tz}\right] \operatorname{Trp}(\mathrm{Boc})-\mathrm{OBn}$

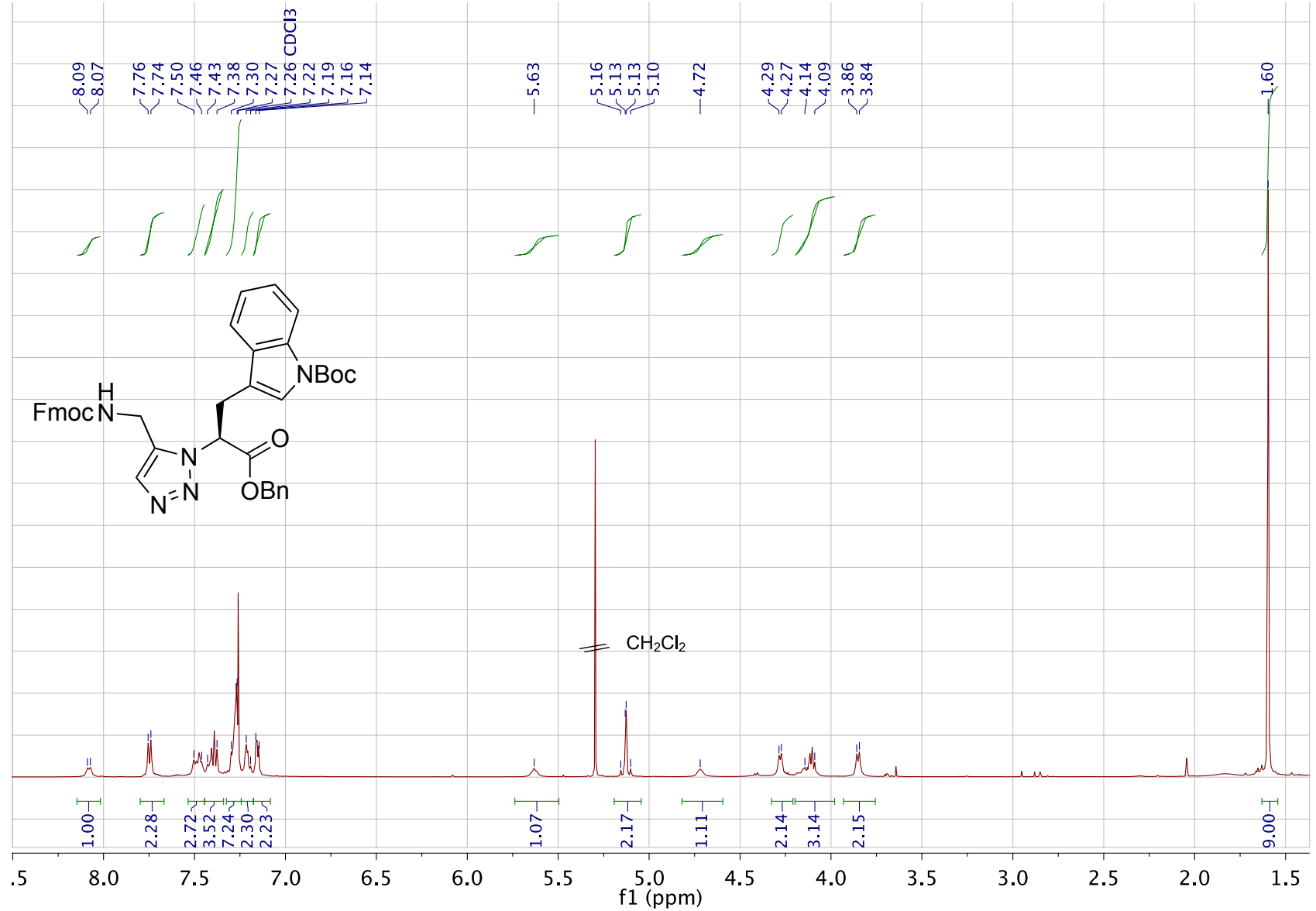

${ }^{13} \mathrm{C}$ spectrum of 13

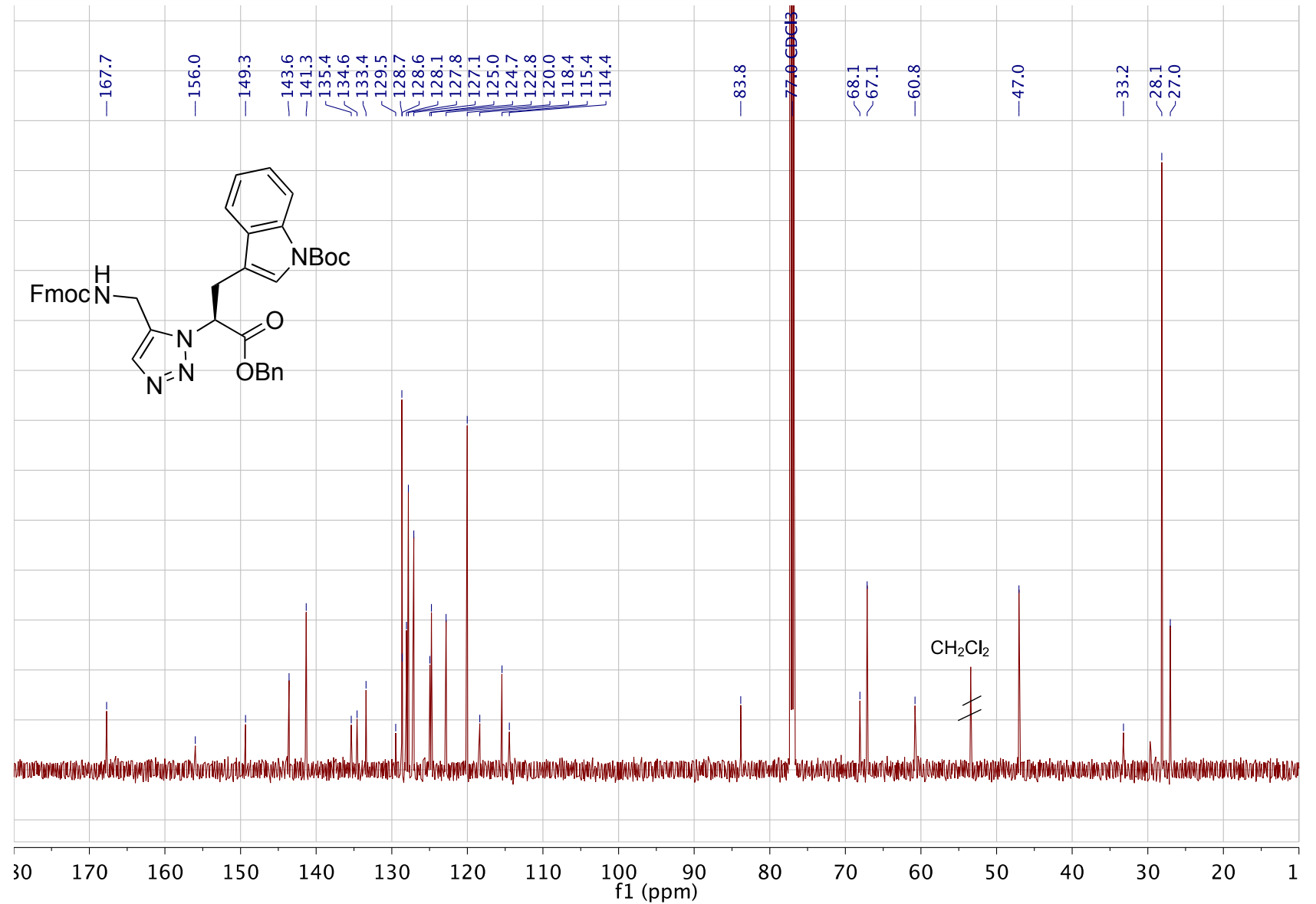

*peaks observed at $5.3 \mathrm{ppm}, 53.5$, and $29.7 \mathrm{ppm}$ correspond to trace amounts of dichloromethane and grease 
${ }^{1} \mathrm{H}$ spectrum of 14 , Fmoc-Ala $\Psi\left[{ }^{1,5} \mathrm{Tz}\right] \mathrm{Ty}(\mathrm{tBu})-\mathrm{OBn}$

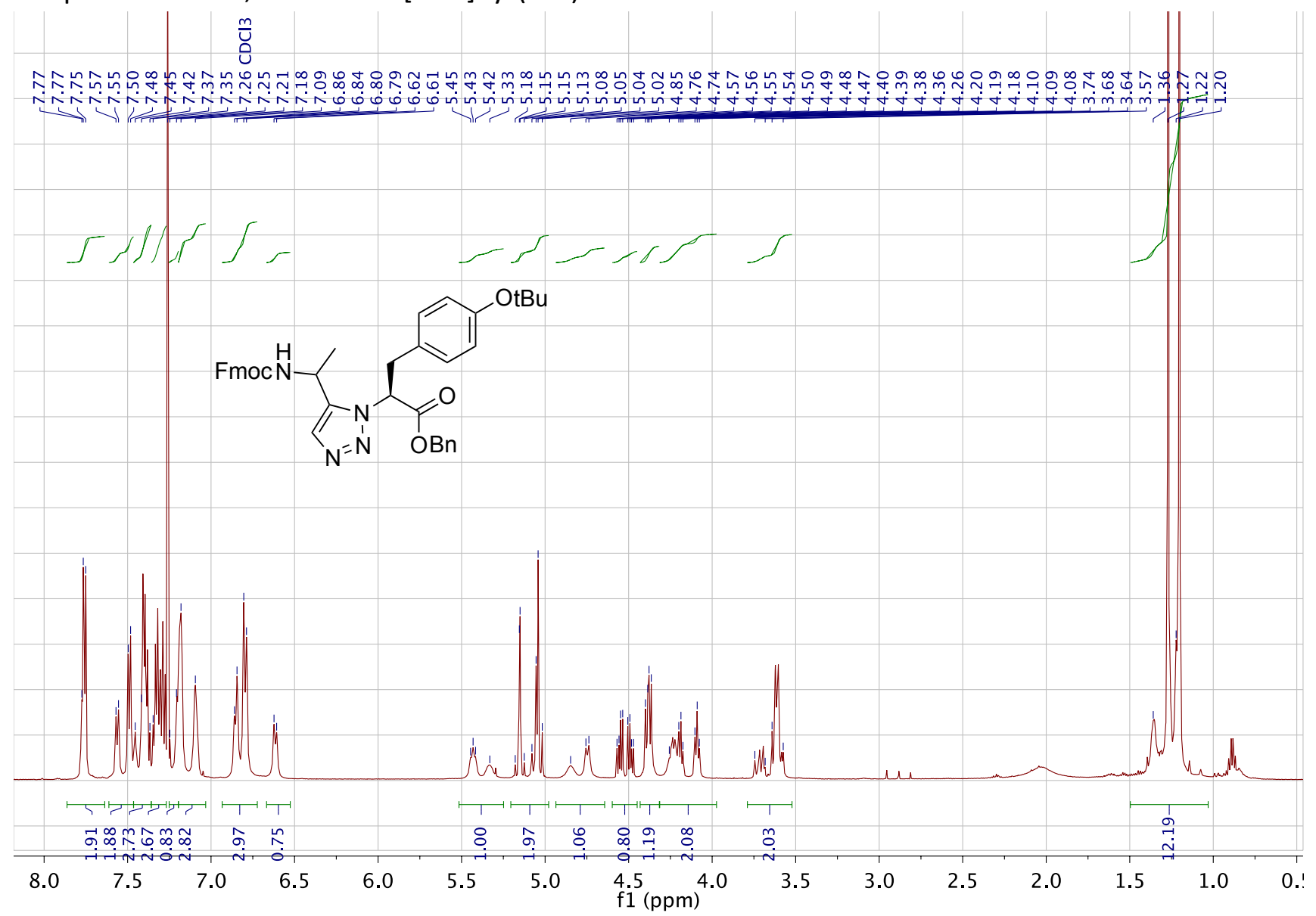

${ }^{13} \mathrm{C}$ spectrum of 14

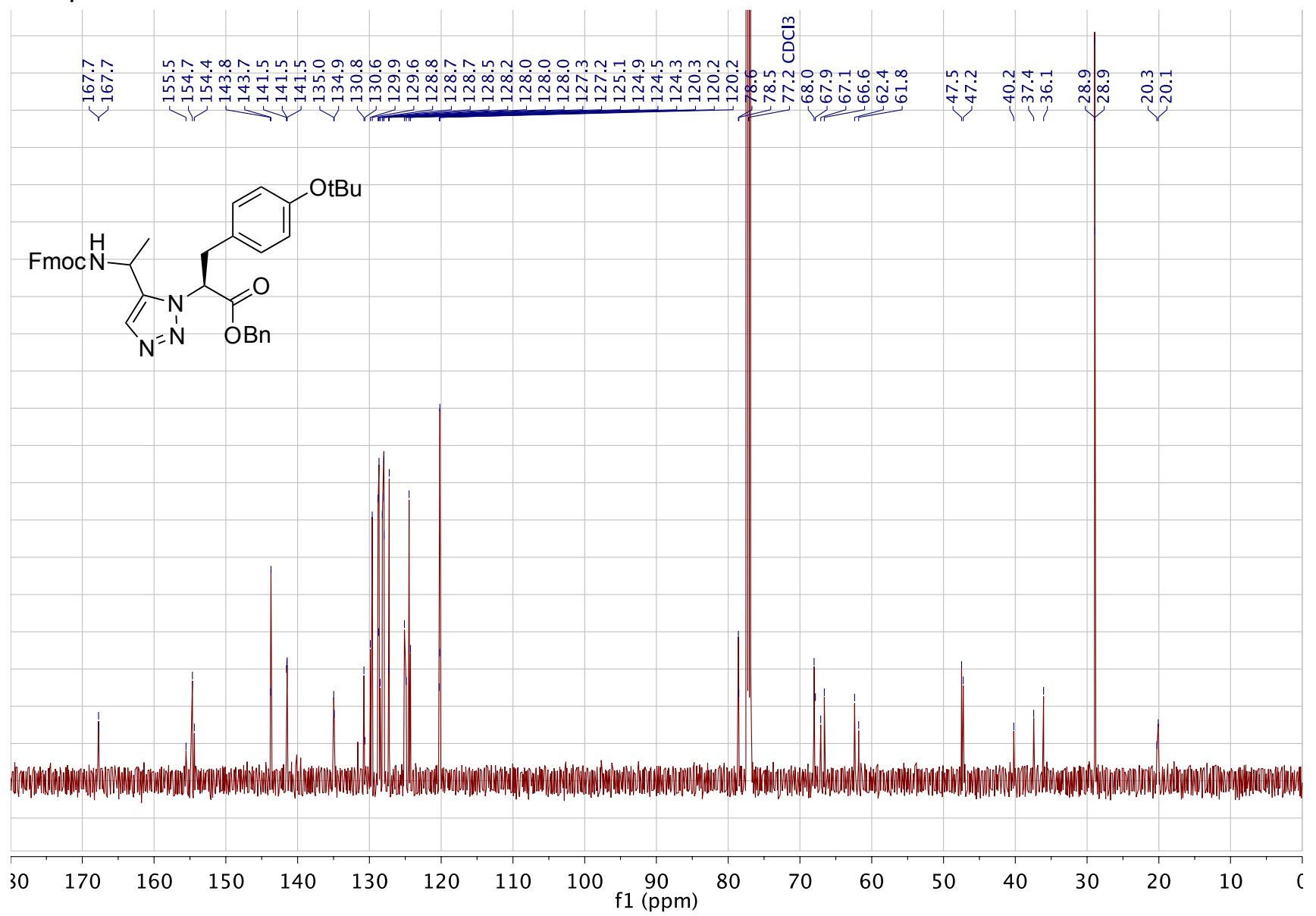


${ }^{1} \mathrm{H}$ spectrum of 15 , Fmoc-Tyr $\left.(\mathrm{tBu}) \Psi^{1,5} \mathrm{Tz}\right] \mathrm{Gly}-\mathrm{OBn}$

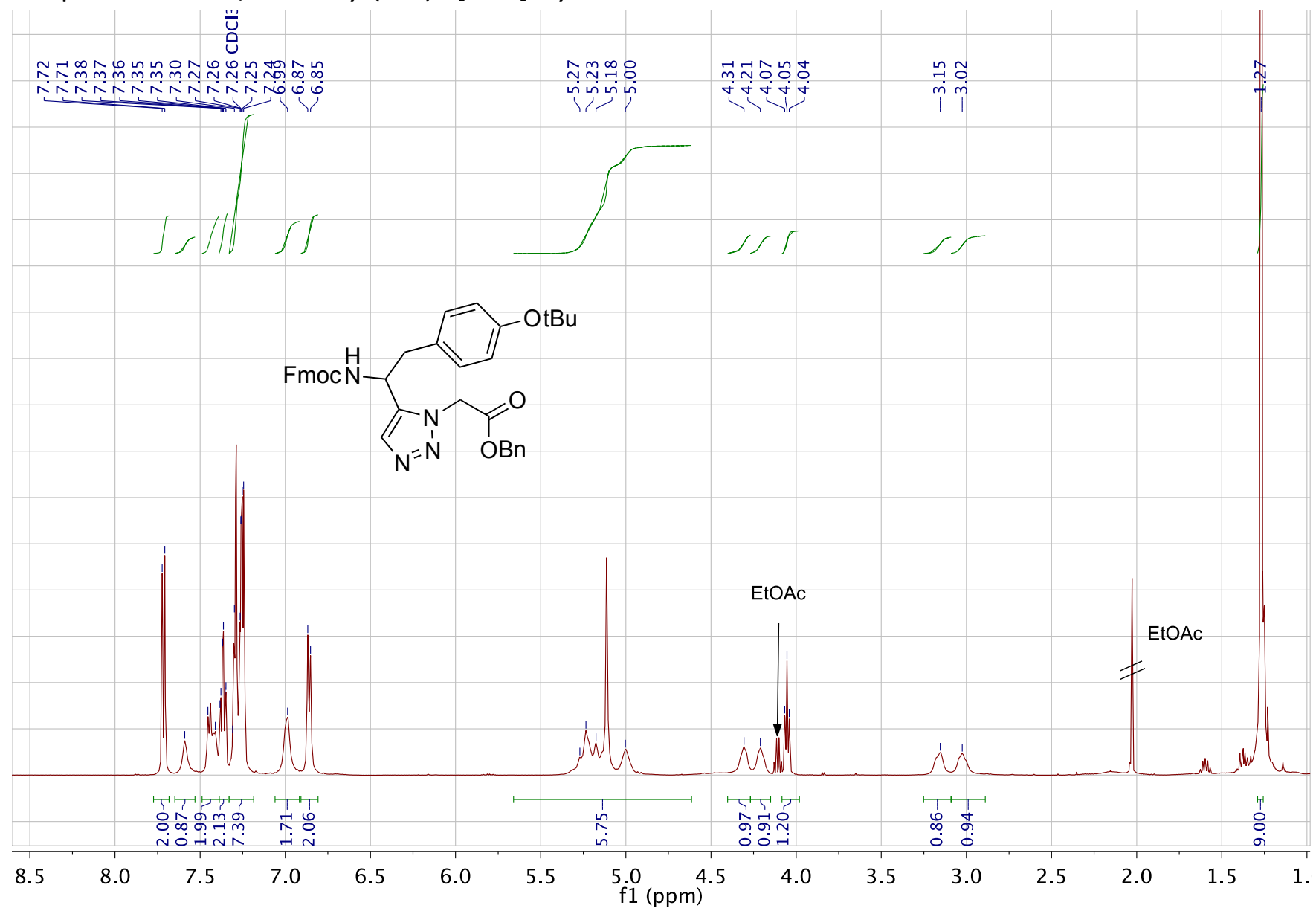

${ }^{13} \mathrm{C}$ spectrum of 15

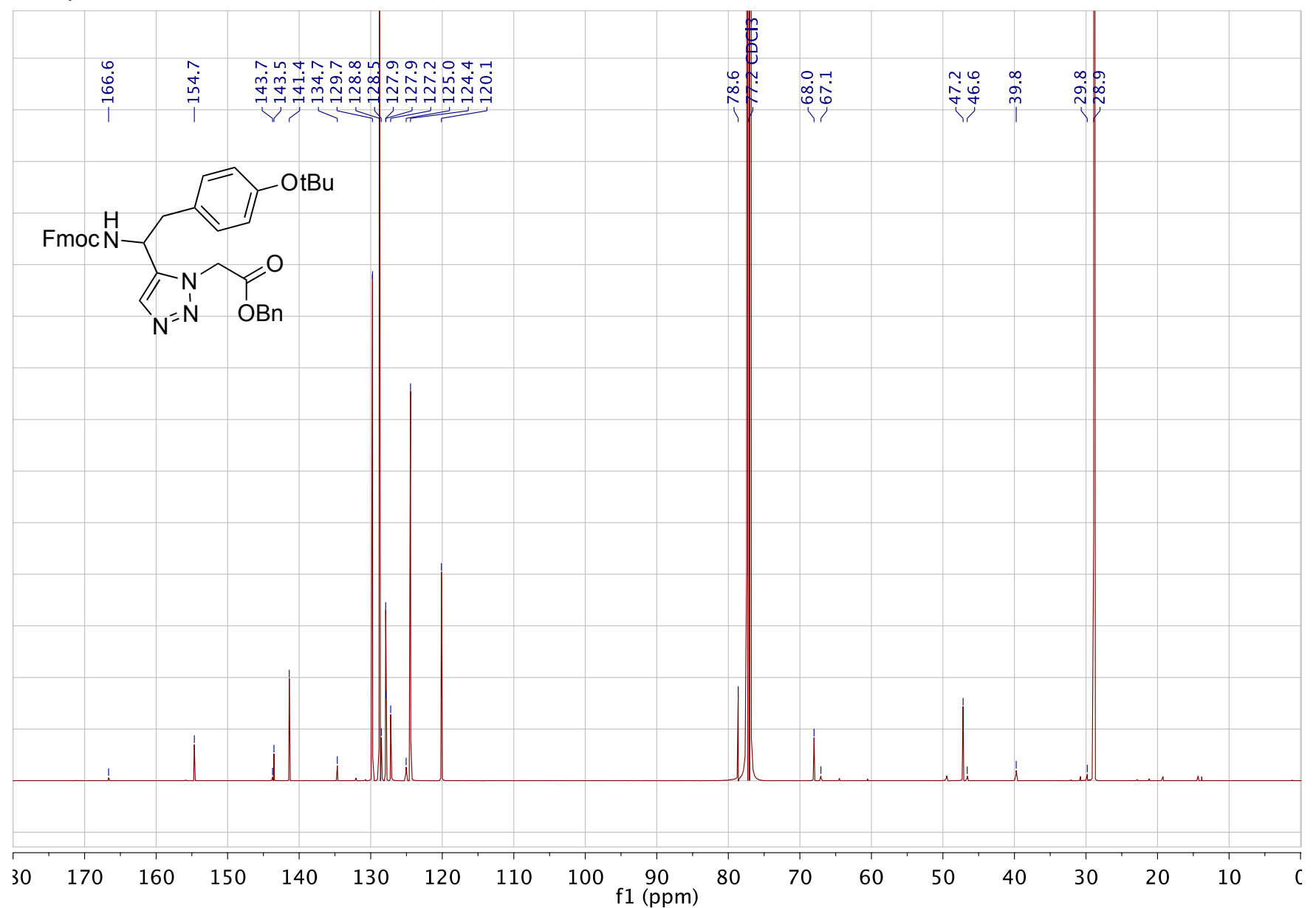


${ }^{1} \mathrm{H}$ spectrum of 16 , Fmoc-Gly $\left.\Psi^{1,5} \mathrm{Tz}\right] \operatorname{Trp}(\mathrm{Boc})-\mathrm{OH}$

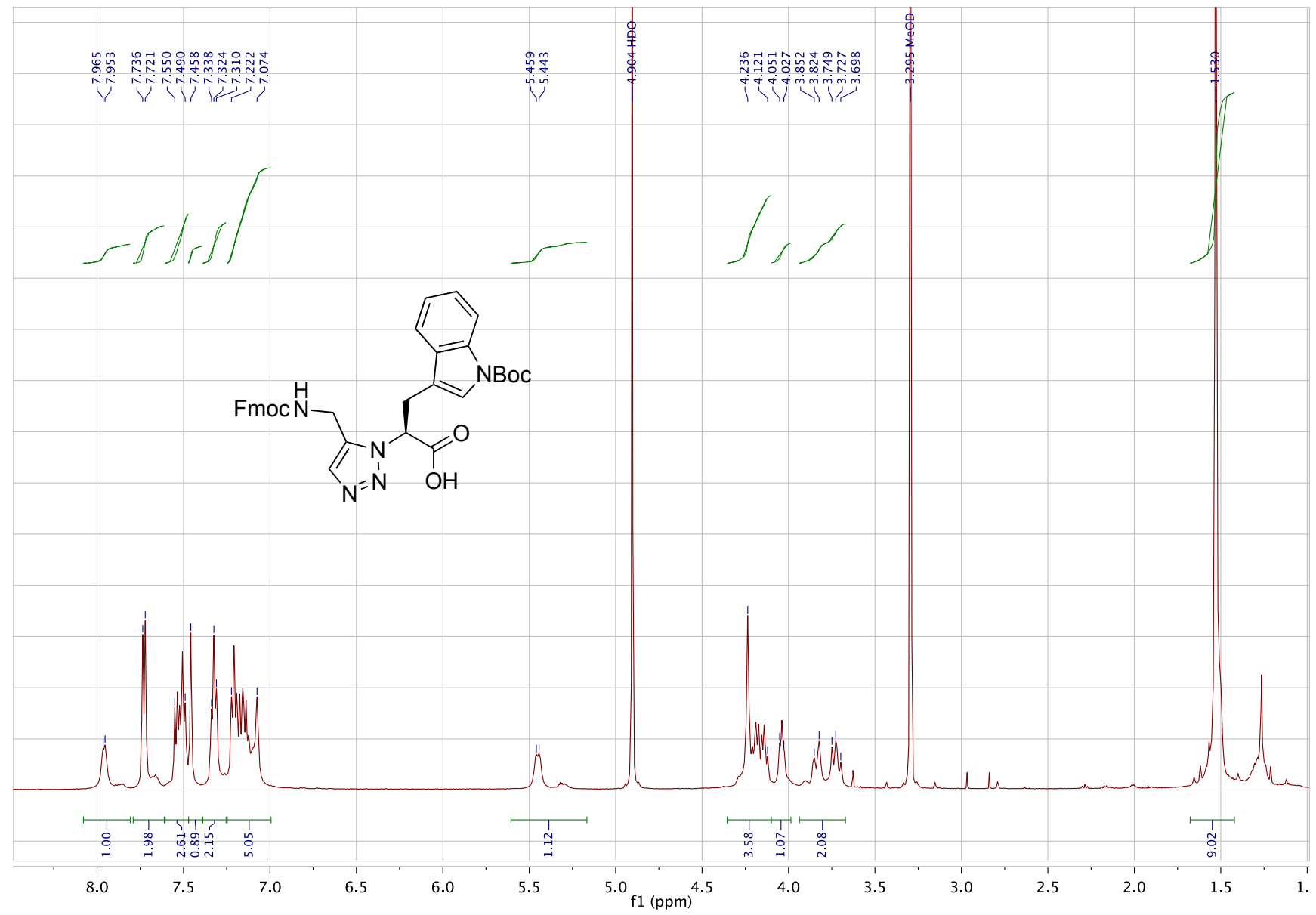

${ }^{13} \mathrm{C}$ spectrum of 16

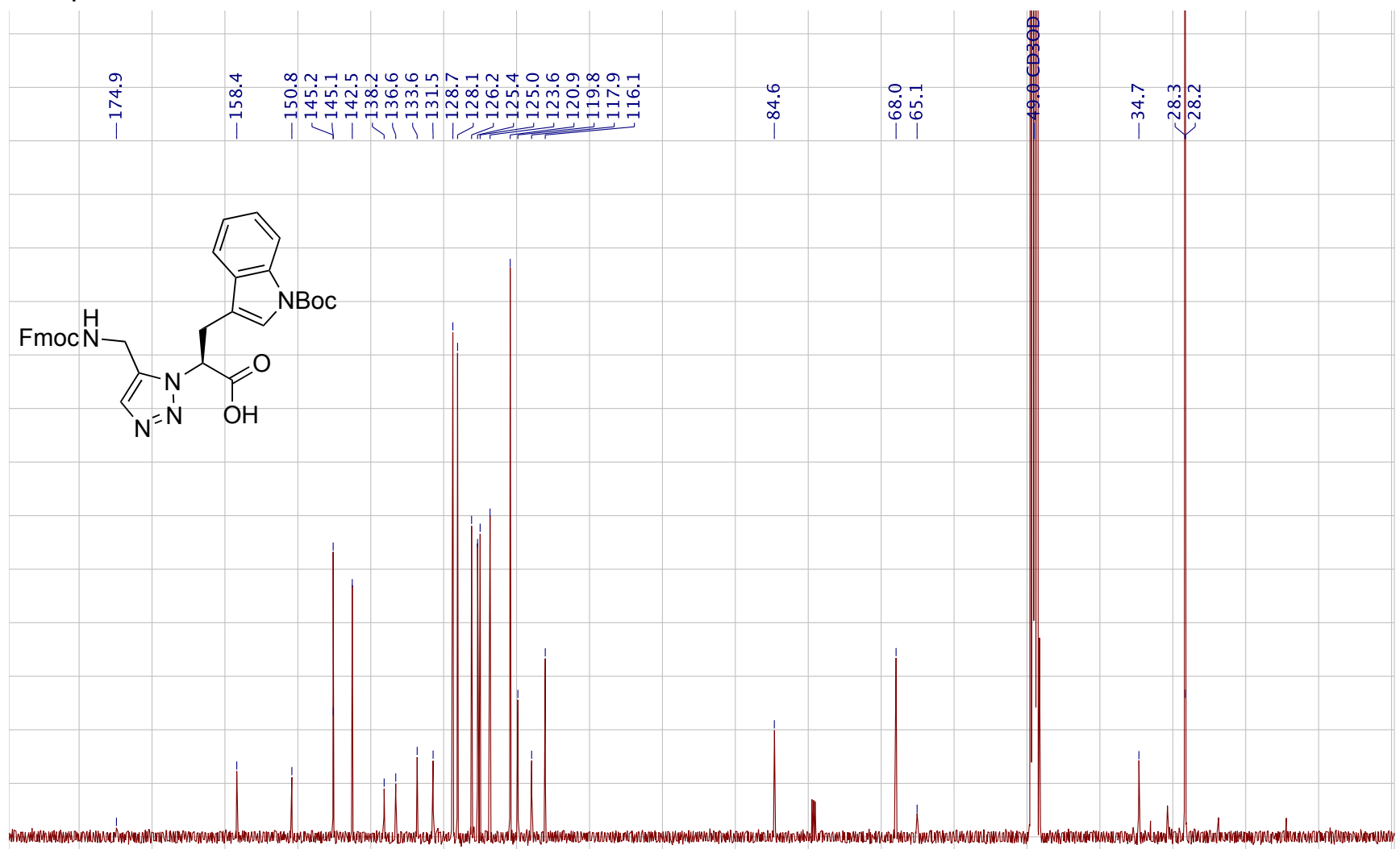

$\begin{array}{lllllllllllllllllll}180 & 170 & 160 & 150 & 140 & 130 & 120 & 110 & 100 & 90 & 80 & 70 & 60 & 50 & 40 & 30 & 20 & 10 & 0\end{array}$

Due to the high number of scans required to see the carboxylic acid signal (174.8 ppm), some traces of $\mathrm{CDCl}_{3}$, "grease", and pentane can be seen in the spectrum at 77.9, 31.3, 14.4, 23.4, and 35.3 ppm respectively. 
${ }^{1} \mathrm{H}$ spectrum of 17 , Fmoc-Ala $\left.\Psi^{1,5} \mathrm{Tz}\right] \mathrm{Tyr}(\mathrm{tBu})-\mathrm{OH}$

岁

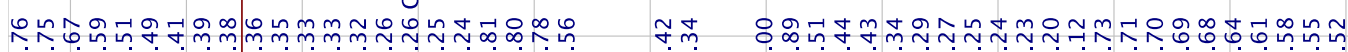

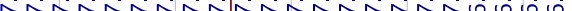

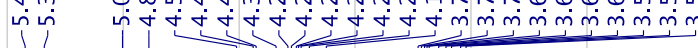

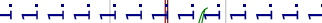
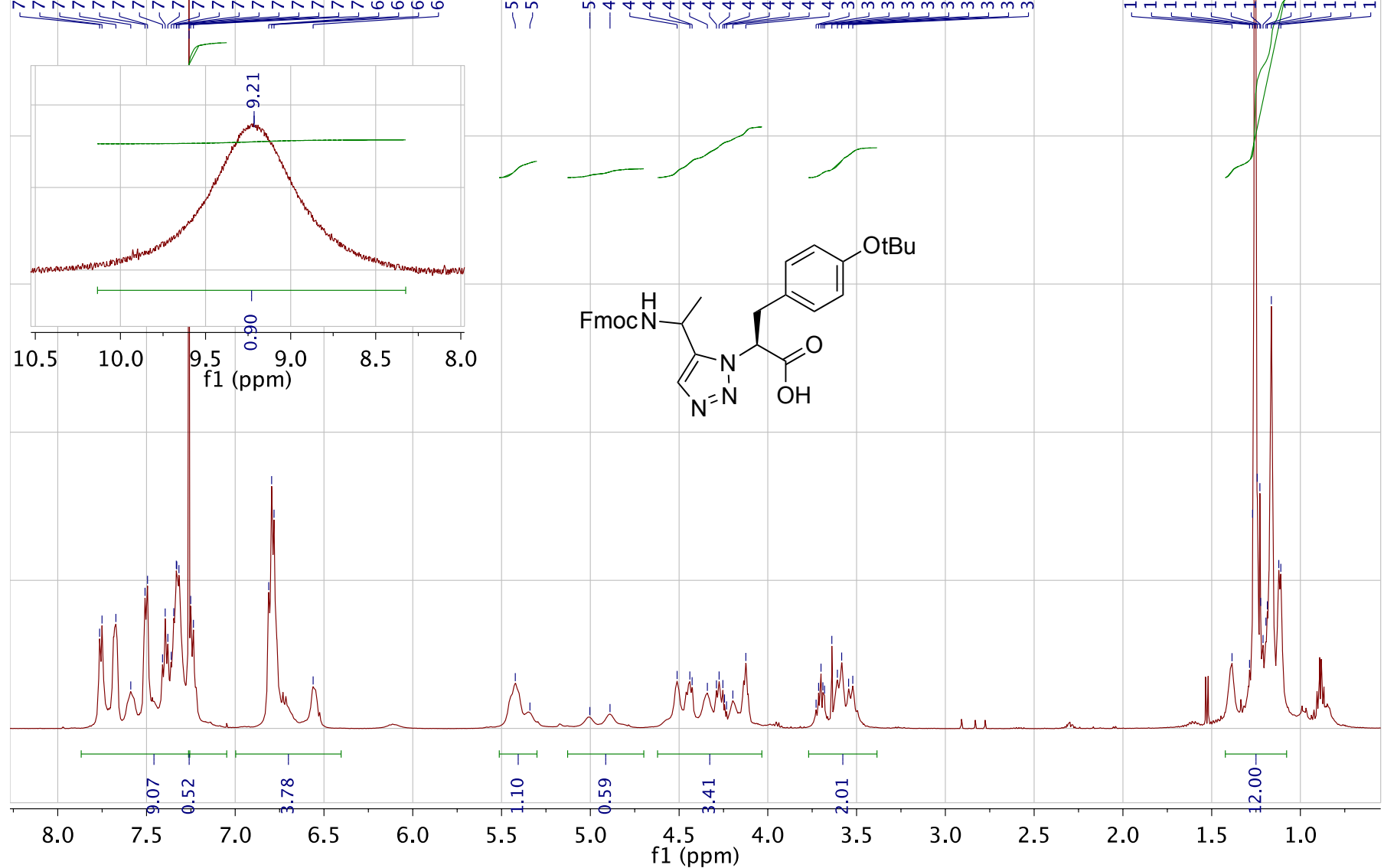

${ }^{13} \mathrm{C}$ spectrum of compound 17

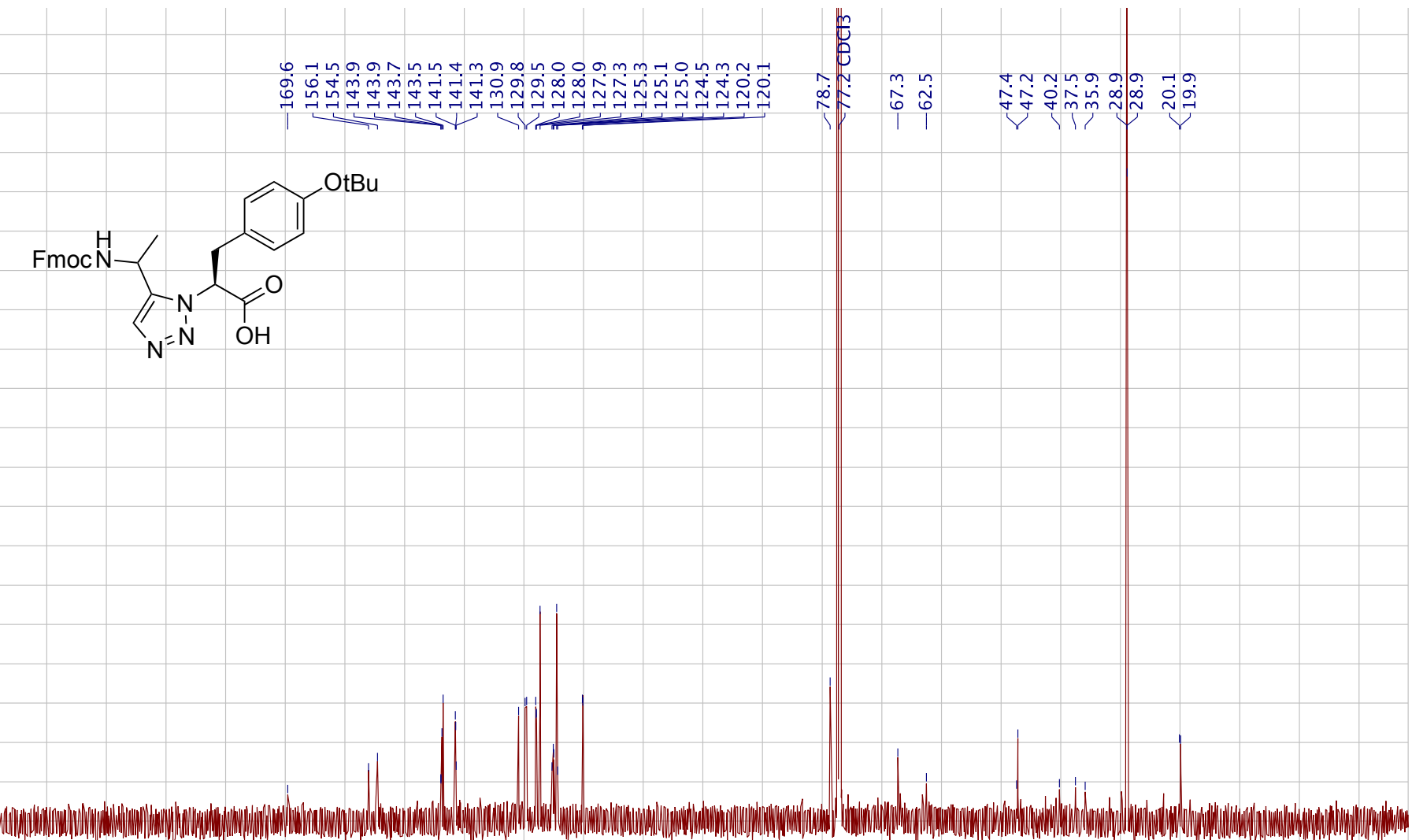

$$
\begin{array}{lllllllllllllllllllllll}
210 & 200 & 190 & 180 & 170 & 160 & 150 & 140 & 130 & 120 & 110 \underset{\mathrm{f} 1}{100}(\mathrm{ppm})
\end{array}
$$


${ }^{1} \mathrm{H}$ spectrum of 18, Fmoc-Tyr(tBu) $\left.\Psi^{1,5} \mathrm{Tz}\right] \mathrm{Gly}-\mathrm{OH}$

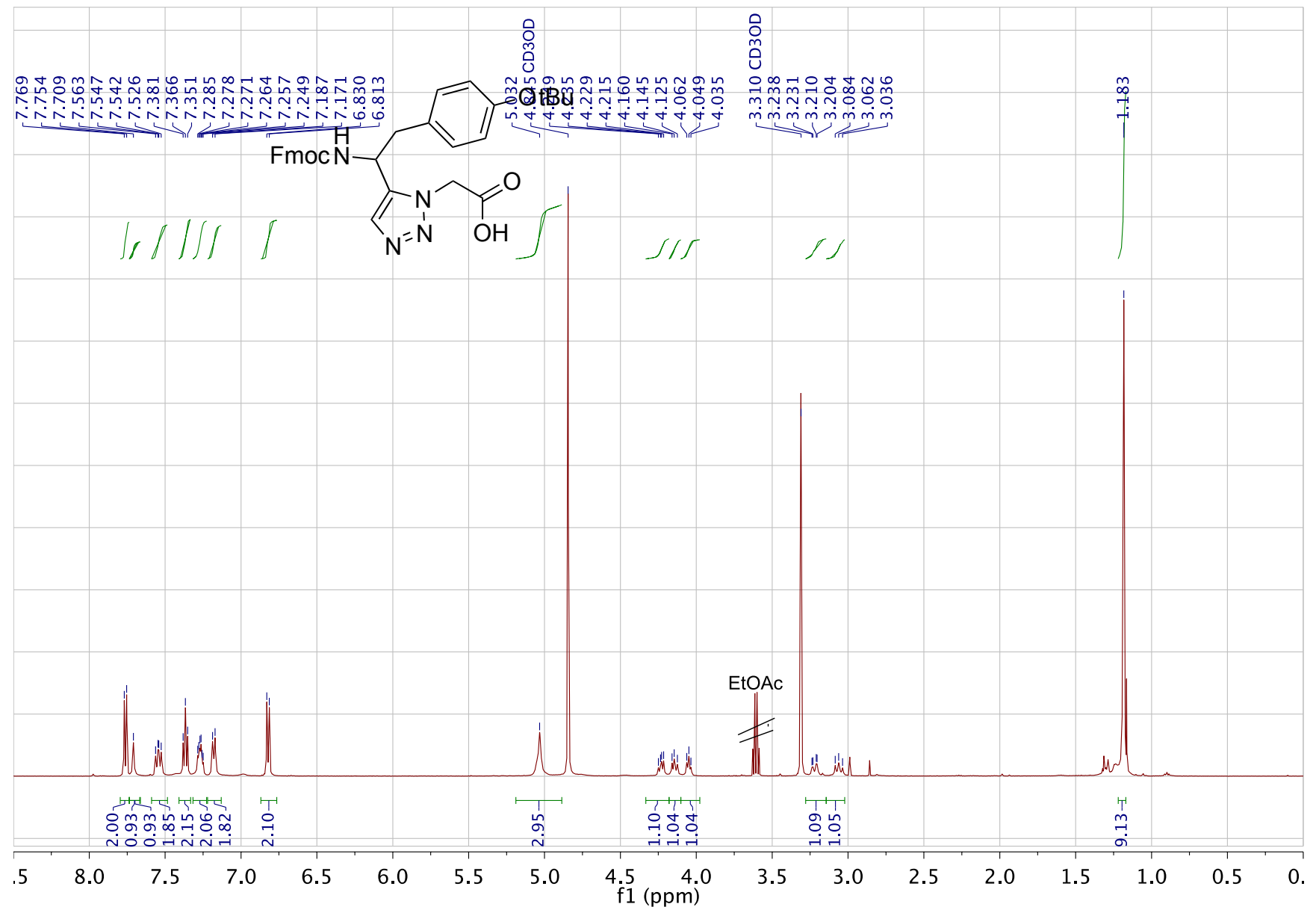

${ }^{13} \mathrm{C}$ spectrum of 18

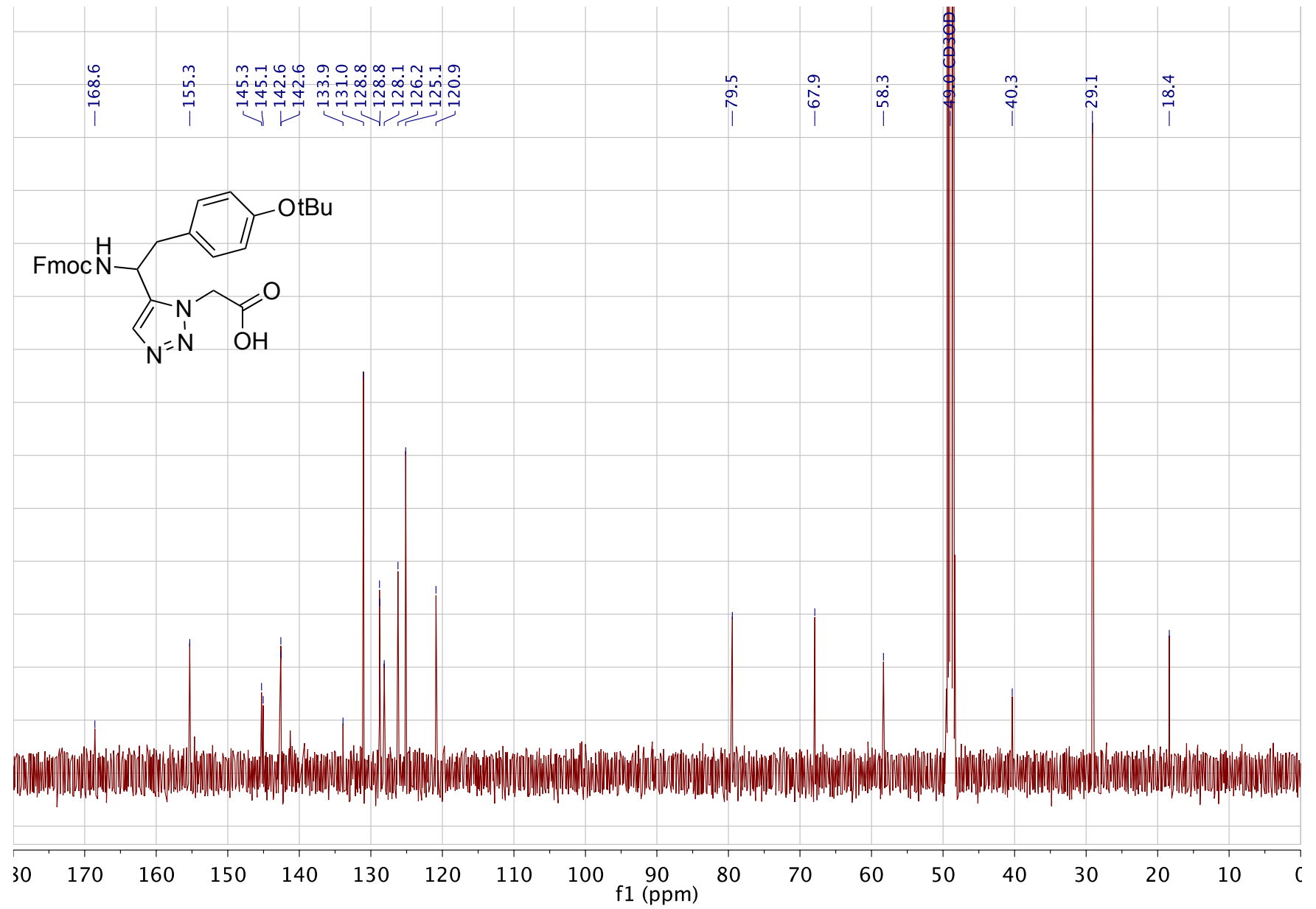


MS spectrum of compound 10

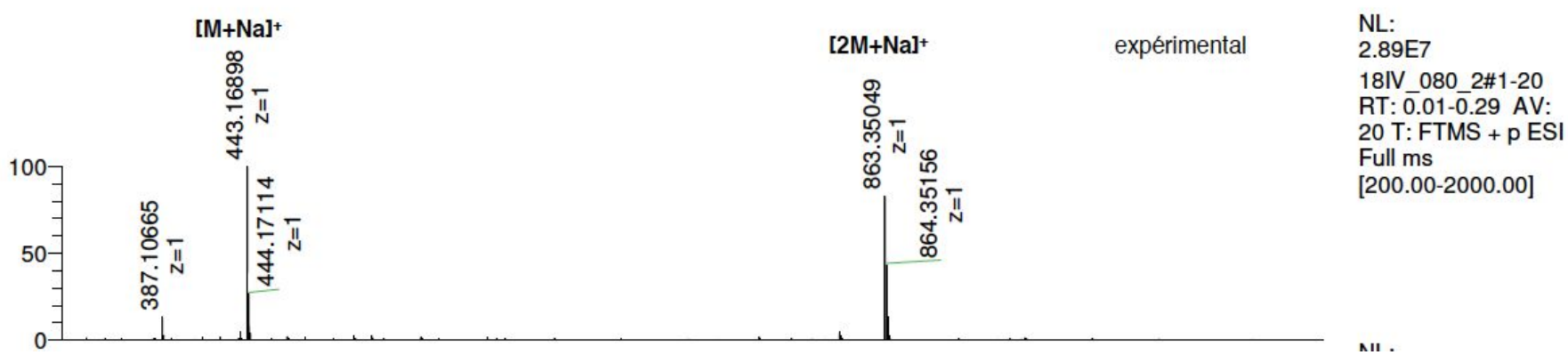

MS spectrum of compound $\mathbf{1 1}$

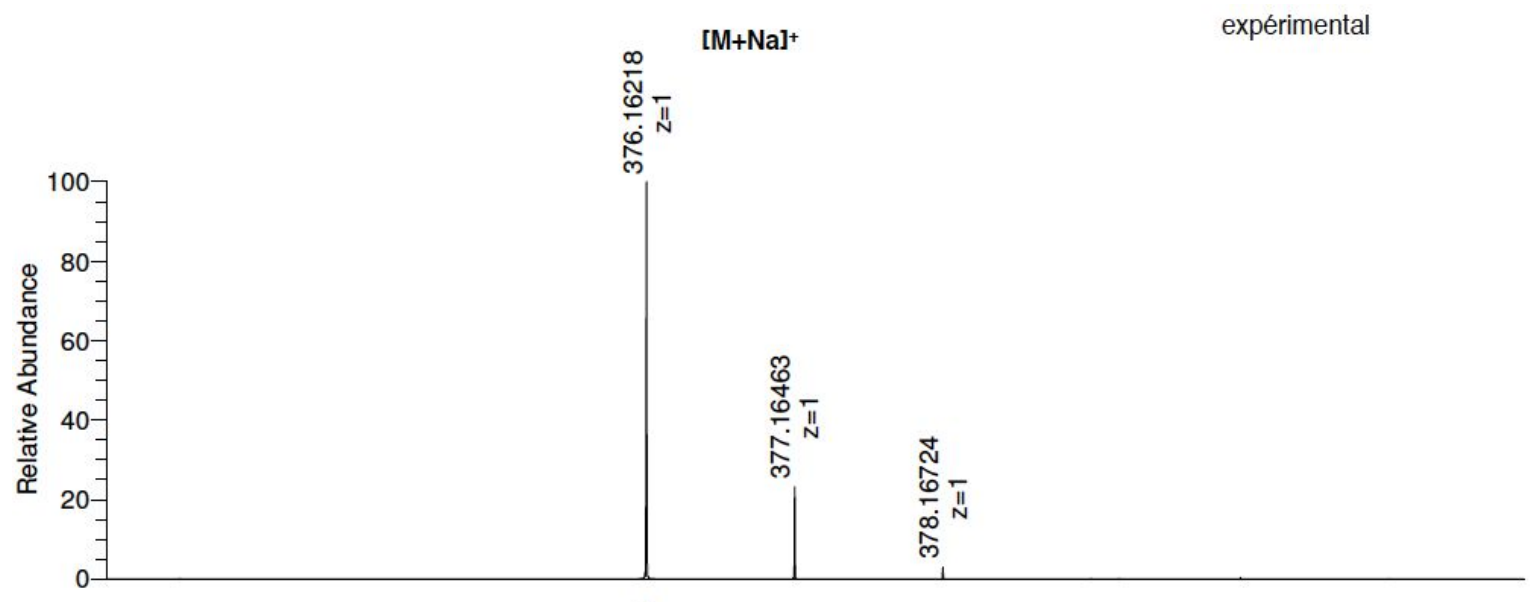

NL:

1.09E8

19iv 104_3\#4-17

RT: $0.05-\overline{0} .24$ AV:

$14 \mathrm{~T}: \mathrm{FTMS}+\mathrm{p}$ ESI

[200.00-2000.00]

NL:

MS spectrum of compound 13

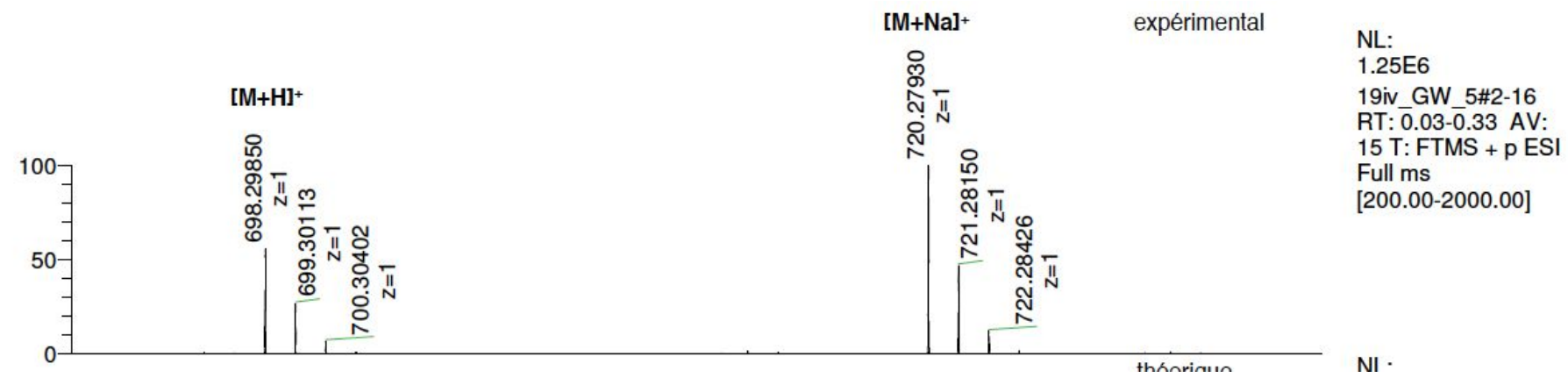

MS spectrum of compound 14

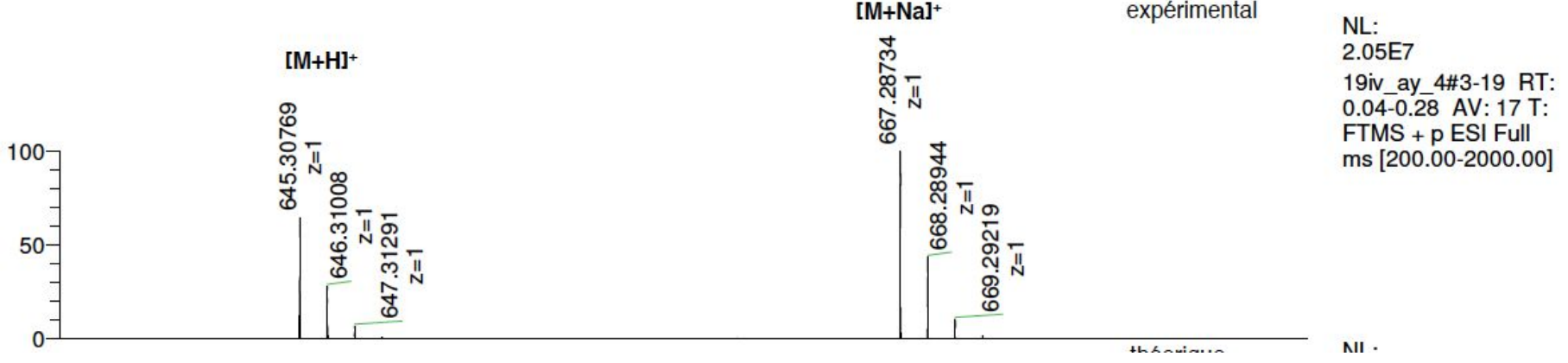




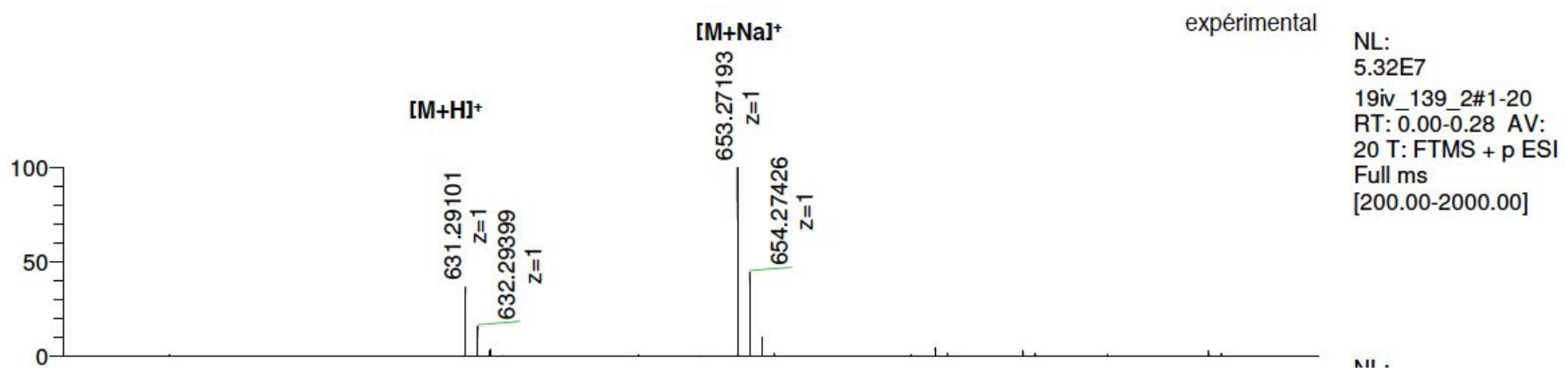

MS spectrum of compound 16

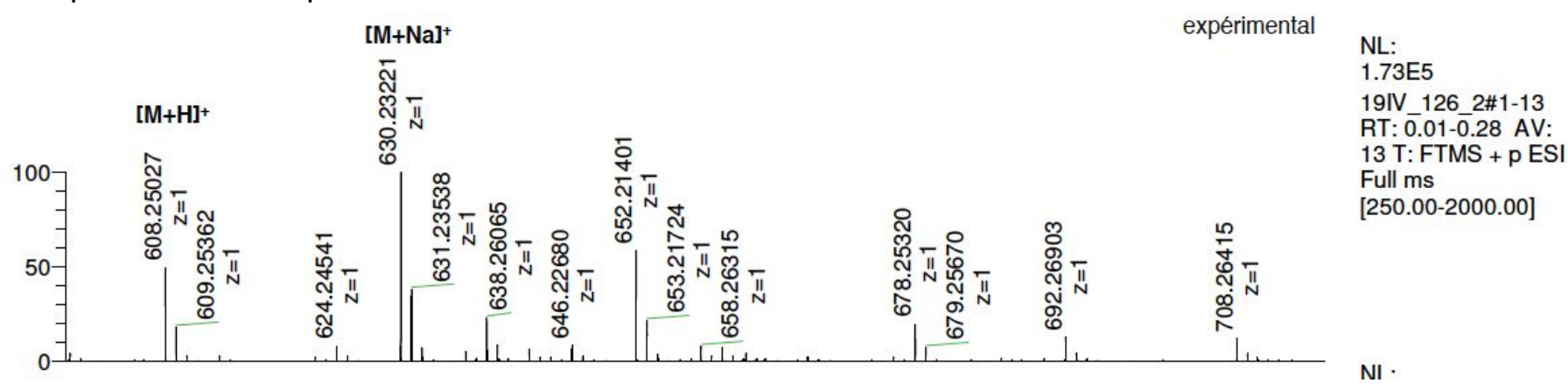

MS spectrum of compound $\mathbf{1 7}$

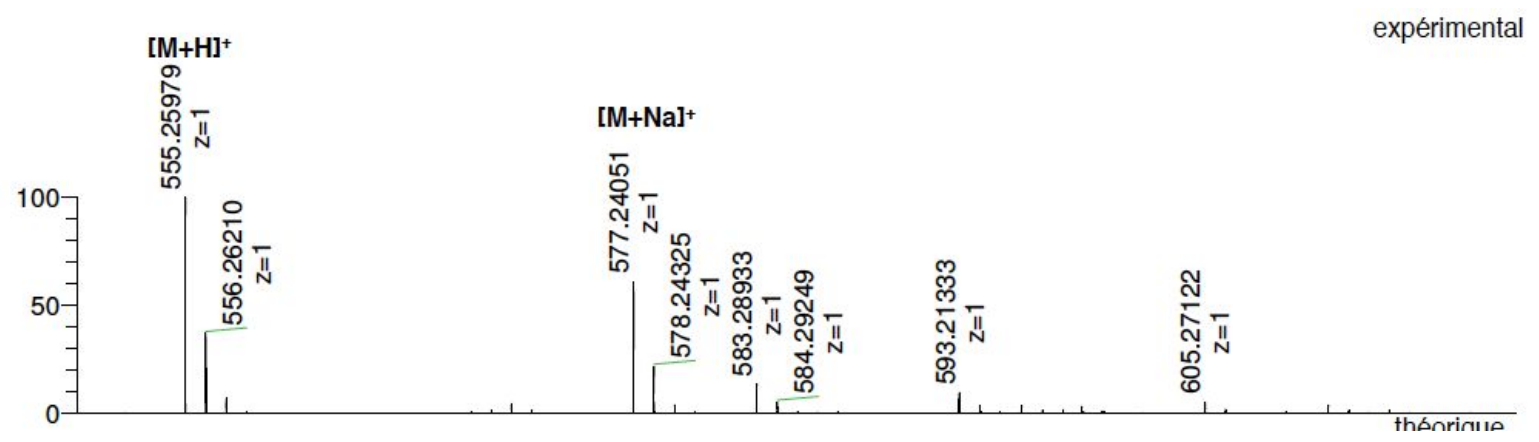

NL:

2.27E6

19iv_131_1\#1-16

RT: 0.01-0.29 AV:

$16 \mathrm{~T}: \mathrm{FTMS}+\mathrm{p} \mathrm{ESI}$

Full $\mathrm{ms}$

[200.00-2000.00]

NII .

MS spectrum of compound $\mathbf{1 8}$

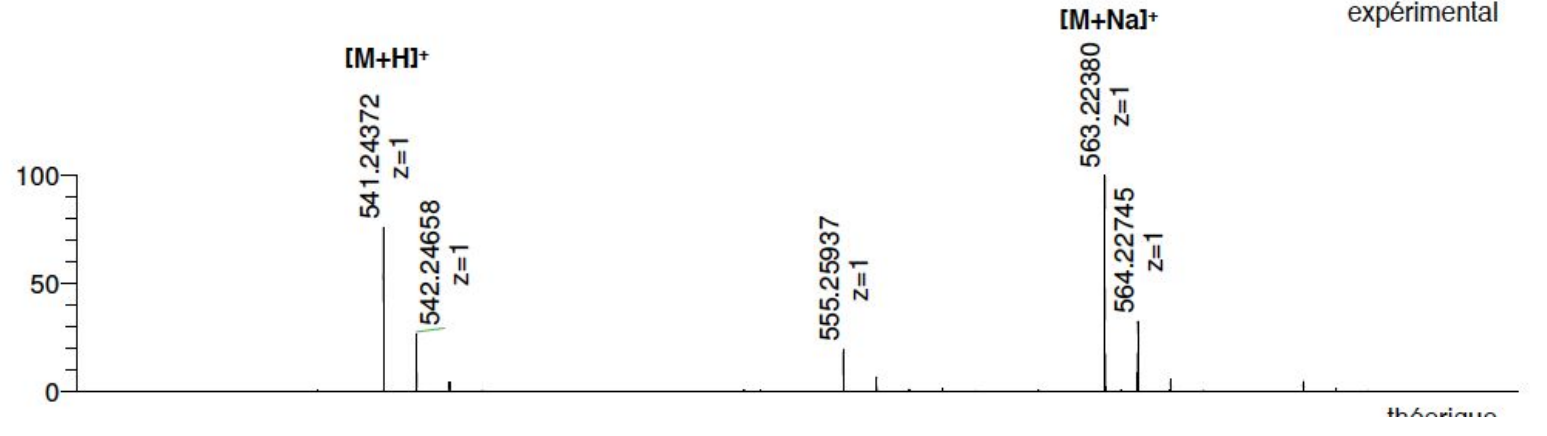

$\mathrm{NL}:$

$2.51 \mathrm{E} 6$

19iv_149_32-18

RT: 0.03-0.28 AV:

17 T: FTMS + p ESI

Full $\mathrm{ms}$

[200.00-2000.00]

NL: 
Infrared spectra

IR spectrum of compound $\mathrm{N}_{3} \operatorname{Trp}(\mathrm{Boc})-\mathrm{OBn} 10$

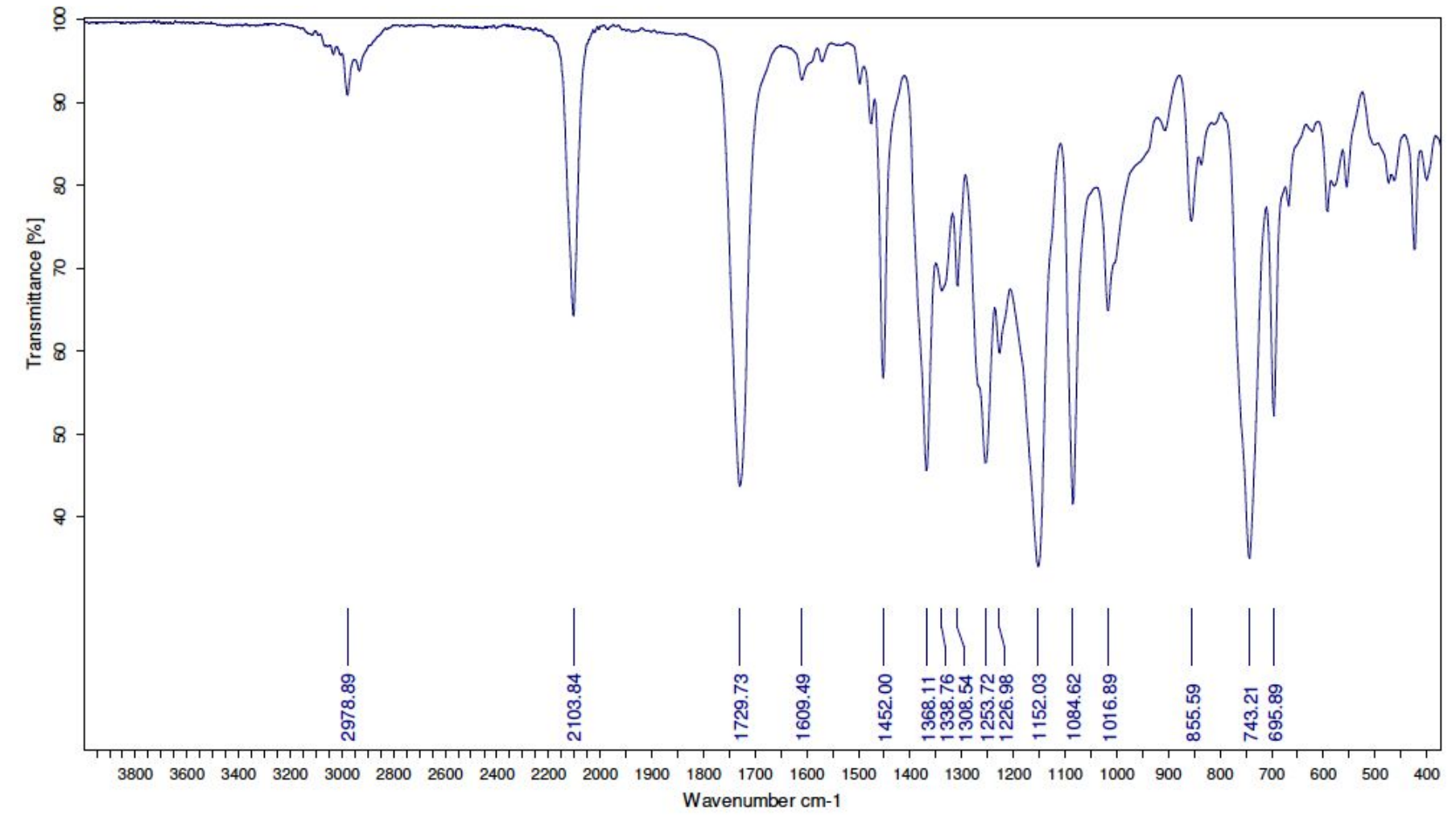

IR spectrum of compound $\mathrm{N}_{3} \mathrm{Ty}(\mathrm{tBu})-\mathrm{OBn} 11$

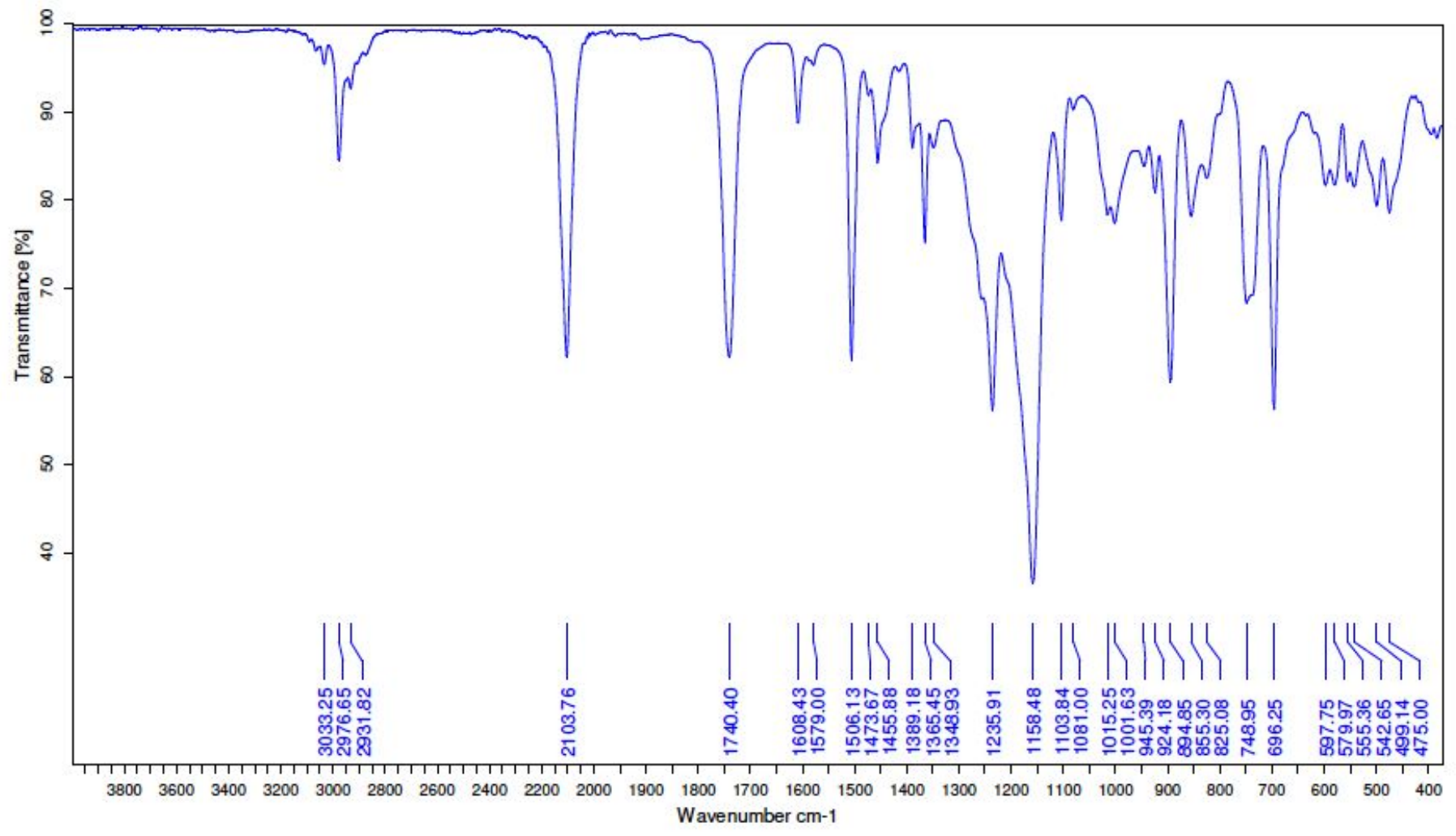




\section{General procedure for manual peptide synthesis}

Fmoc-protected amino acids were manually coupled onto the resin in a syringe fitted with a polypropylene frit and a Teflon tap. Briefly, to the resin $(0.03 \mathrm{mmol}$, swollen in peptide-synthesis grade DMF) were successively added the Fmoc-protected amino acid or dipeptide analogs (2 equiv, 0.06 mmol), HATU (2 equiv), and DIEA ( 5 equiv), and the suspension was shaken at RT for $1 \mathrm{~h}$. The solvent and excess reagents were then removed by filtration, and the resin was thoroughly washed by $\mathrm{DMF}$ and $\mathrm{CH}_{2} \mathrm{Cl}_{2}$. The completion of the reaction was checked by the Kaiser test and repeated if necessary. Fmoc-protected amino acids were deprotected by addition of a solution of $20 \%$ piperidine in DMF to the peptide resin. The suspension was then allowed to react for $3 \mathrm{~min}$. The treatment was repeated three times. The solvent and excess reagents were then removed by filtration, and the resin was washed thoroughly with $\mathrm{DMF}$ and $\mathrm{CH}_{2} \mathrm{Cl}_{2}$. The peptide resin was cleaved and deprotected by a standard $5 \mathrm{~h}$ treatment with a mixture of $\mathrm{TFA} / \mathrm{H}_{2} \mathrm{O} / \mathrm{i}-\mathrm{Pr} \mathrm{SiH}_{3} \mathrm{PhOH}$ (87.5:5:2.5:5). The conjugate was then precipitated with ice-cold diethyl ether, recovered by centrifugation, and washed twice with cold diethyl ether. The precipitate was purified by preparative HPLC, and the peptide conjugates were isolated as yellowish to white powders after lyophilization.

\section{$\left[\mathrm{Gly}^{13} \psi[\mathrm{Tz}] \operatorname{Trp}^{14}, \mathrm{Nle}^{15}\right] \mathrm{MG} 11$ (peptidomimetic 5)}

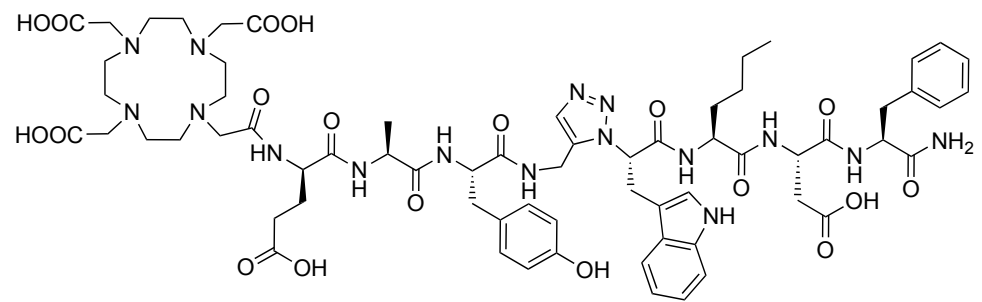

Chemical Formula: $\mathrm{C}_{66} \mathrm{H}_{88} \mathrm{~N}_{16} \mathrm{O}_{19}$

Exact Mass: 1408,64

Molecular Weight: 1409,52

The peptidomimetic was synthesized using the procedure described above. The compound was obtained in $32 \%$ yield $(23 \mathrm{mg})$ in at least $95 \%$ purity.

ESI-HRMS : $[\mathrm{M}+\mathrm{H}]^{+} m / z=1409.64947$ (calcd. for $\mathrm{C}_{66} \mathrm{H}_{89} \mathrm{~N}_{16} \mathrm{O}_{19}:$ 1409.64844).

$\left[\mathrm{Tyr}^{12} \psi[\mathrm{Tz}] \mathrm{Gly}{ }^{13}, \mathrm{Nle}^{15}\right] \mathrm{MG} 11$ (peptidomimetic 6)

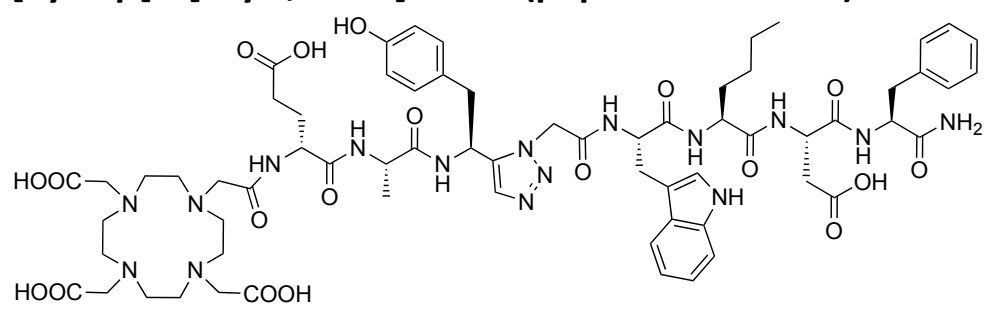

The peptidomimetic was synthesized using the procedure described above. The diastereoisomers were separated by preparative HPLC. The compound was obtained in $50 \%$ yield $(14 \mathrm{mg})$ in at least $95 \%$ purity.

ESI-HRMS : $[\mathrm{M}+\mathrm{H}]^{+} m / z=1409.64909$ (calcd. for $\mathrm{C}_{66} \mathrm{H}_{89} \mathrm{~N}_{16} \mathrm{O}_{19}: 1409.64844$ ).

Partial racemization was observed during the synthesis of $\mathbf{9}$ and the alkyne was used as a mixture of enantiomers during SPPS. After elongation, cleavage and deprotection, the two resulting peptidic diastereoisomers (in 90/10 ratio, as expected) could be separated and isolated by preparative HPLC (see below). Compound 6 was assigned as the major diastereoisomer.

Preparative HPLC chromatogram of the crude mixture obtained after SPPS. gradient : $25-35 \%$ B/A over 20 minutes at a $20.0 \mathrm{~mL} / \mathrm{min}$ flow. 


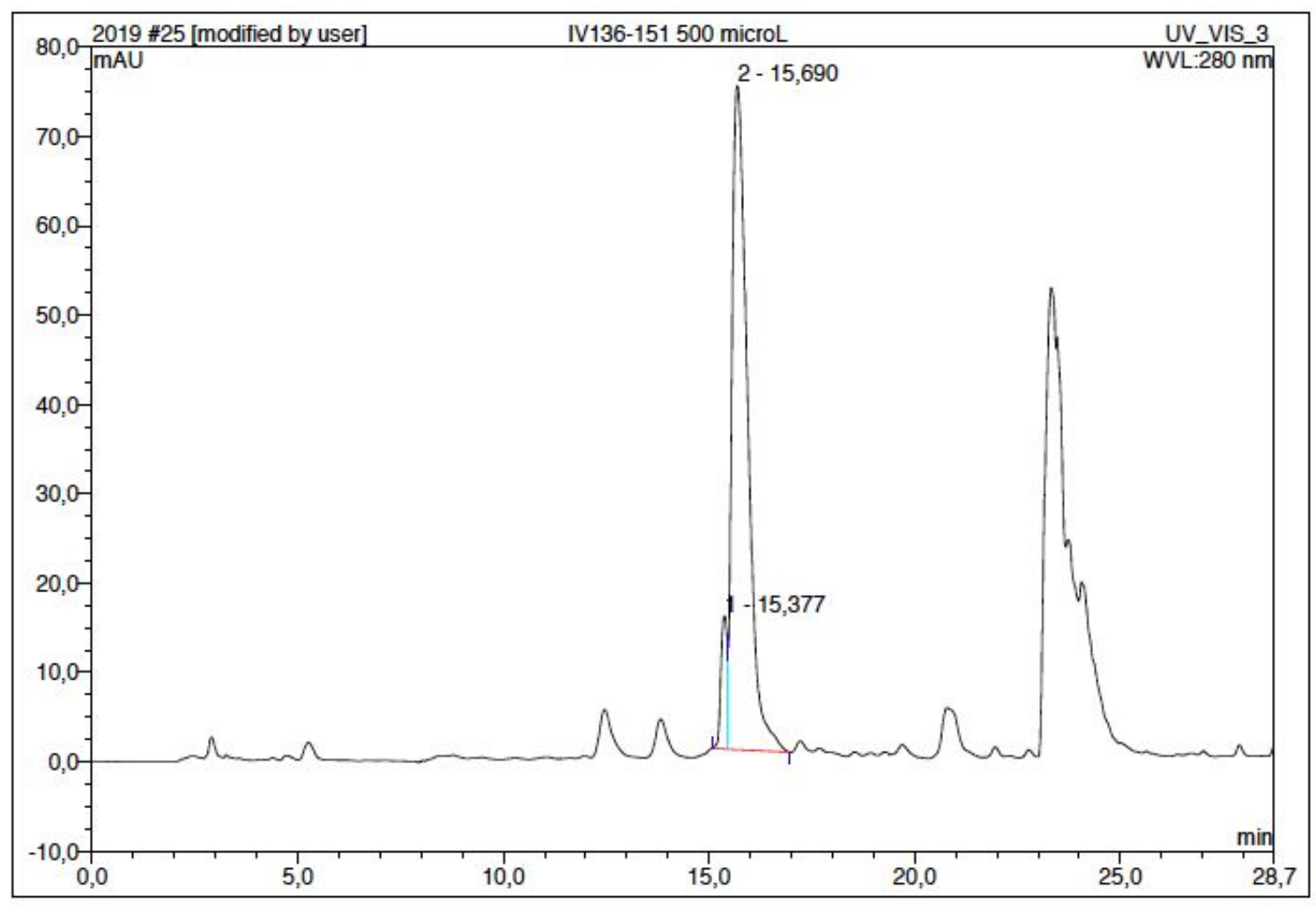

\begin{tabular}{|r|ccrrrrr|}
\hline No. & $\begin{array}{c}\text { Ret.Time } \\
\text { min }\end{array}$ & Peak Name & $\begin{array}{c}\text { Height } \\
\text { mAU }\end{array}$ & $\begin{array}{c}\text { Area } \\
\text { mAU*min }\end{array}$ & $\begin{array}{r}\text { Rel.Area } \\
\%\end{array}$ & Amount & Type \\
\hline 1 & 15,38 & n.a. & 14,906 & 2,694 & 7,65 & n.a. & BM $^{*}$ \\
2 & 15,69 & n.a. & 74,330 & 32,541 & 92,35 & n.a. & MB $^{*}$ \\
\hline Total: & & & 89,237 & 35,235 & 100,00 & 0,000 & \\
\hline
\end{tabular}

The same crude mixture was analyzed by HPLC coupled to LR-MS to confirm that the two compounds had the same $\mathrm{m} / \mathrm{z}$. The chromatographic profile was similar to the one observed in preparative HPLC and the two compounds showed identical $\mathrm{m} / \mathrm{z}$ (see below). ESI-LRMS : $[\mathrm{M}+2 \mathrm{H}]^{2+} \mathrm{m} / \mathrm{z}=705.3$ (calcd. for $\mathrm{C}_{66} \mathrm{H}_{90} \mathrm{~N}_{16} \mathrm{O}_{19}$ : 705.3). 


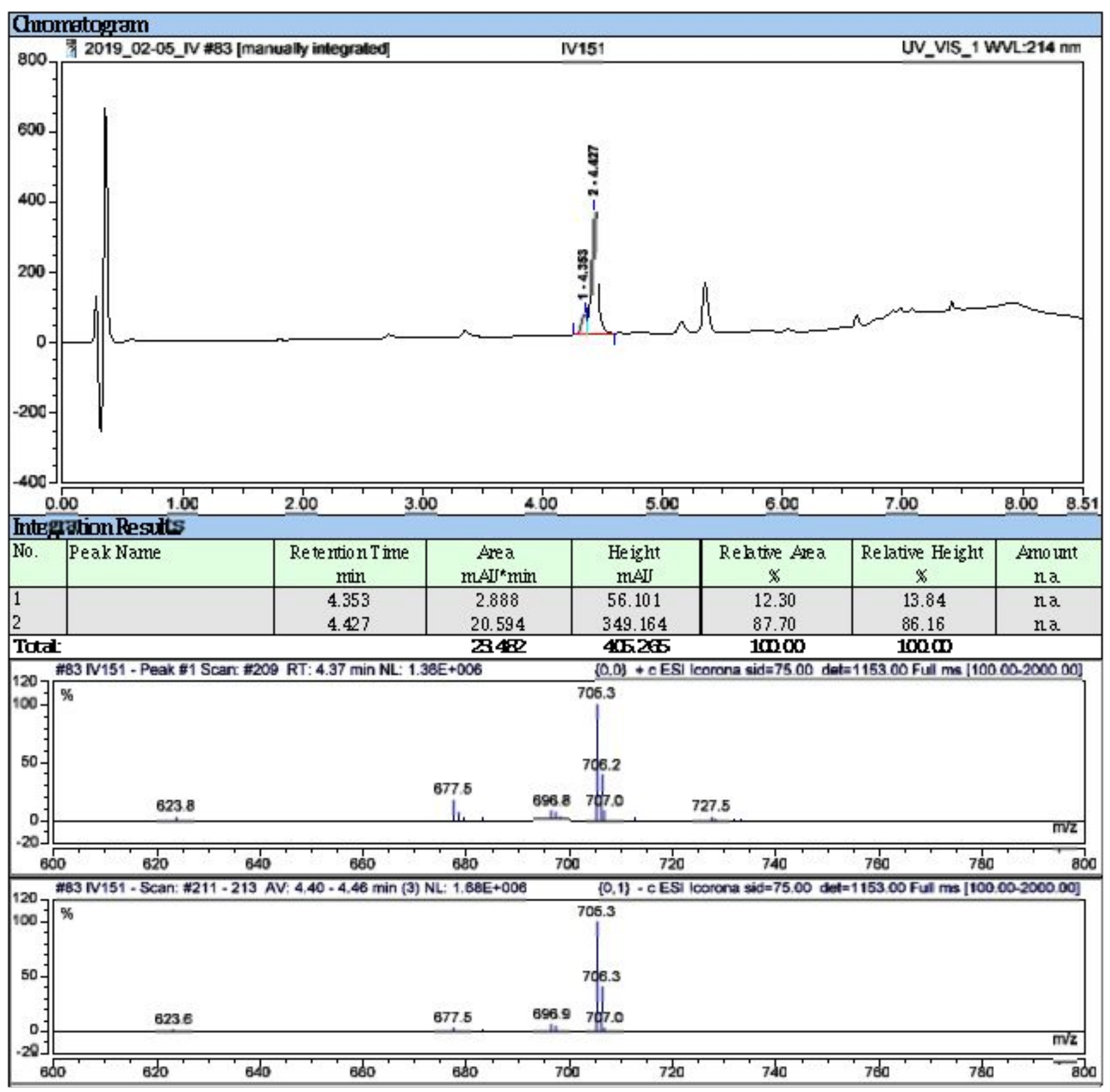

$\left[\right.$ Ala ${ }^{11} \psi\left[\mathrm{Tz}_{\mathrm{T}} \mathrm{Tr}^{12}, \mathrm{Nle}^{15}\right] \mathrm{MG} 11$ (peptidomimetic 7)

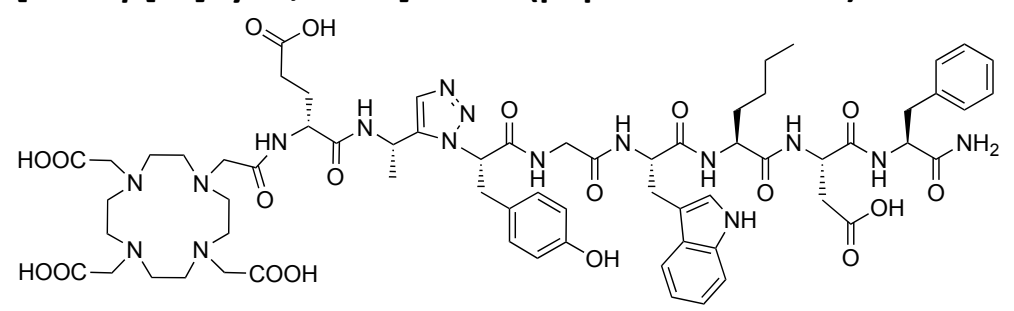

Chemical Formula: $\mathrm{C}_{66} \mathrm{H}_{88} \mathrm{~N}_{16} \mathrm{O}_{19}$

Exact Mass: 1408,64

Molecular Weight: 1409,52

The peptidomimetic was synthesized using the procedure described above. The diastereoisomers were separated by HPLC. The desired compound was obtained in $38 \%$ yield ( $27 \mathrm{mg}$ ) in at least $95 \%$ purity.

ESI-HRMS : $[\mathrm{M}+\mathrm{H}]^{+} m / z=1409.65074$ (calcd. for $\mathrm{C}_{66} \mathrm{H}_{89} \mathrm{~N}_{16} \mathrm{O}_{19}:$ 1409.64844).

Partial racemization was observed during the synthesis of the alkyne and $\mathbf{8}$ was used as a mixture of enantiomers during SPPS. After elongation, cleavage and deprotection, the two resulting peptidic diastereoisomers (in 66/34 ratio, as expected) could be separated and isolated by preparative HPLC (see below). Compound $\mathbf{7}$ was assigned as the major diastereoisomer. 
Preparative HPLC chromatogram of the crude mixture obtained after SPPS. gradient : $25-35 \%$ B/A over 20 minutes at a $20.0 \mathrm{~mL} / \mathrm{min}$ flow.

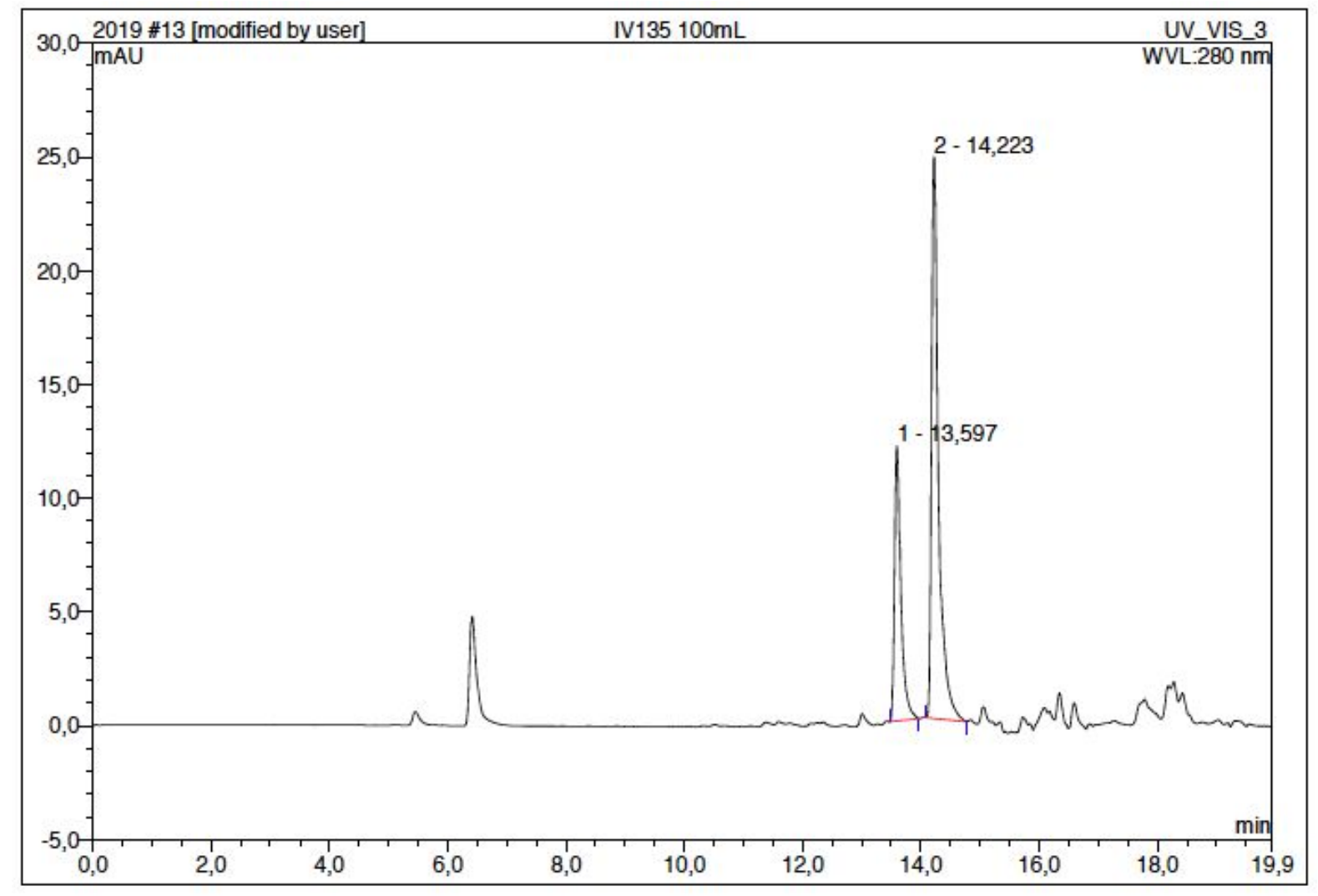

\begin{tabular}{|c|cccrrrr|}
\hline No. & $\begin{array}{c}\text { Ret.Time } \\
\text { min }\end{array}$ & Peak Name & $\begin{array}{c}\text { Height } \\
\text { mAU }\end{array}$ & $\begin{array}{c}\text { Area } \\
\text { mAU*min }\end{array}$ & $\begin{array}{c}\text { Rel.Area } \\
\%\end{array}$ & Amount & Type \\
\hline 1 & 13,60 & n.a. & 12,098 & 1,531 & 31,07 & n.a. & BMB $^{*}$ \\
2 & 14,22 & n.a. & 24,701 & 3,396 & 68,93 & n.a. & BMB \\
\hline Total: & & & & 36,799 & 4,926 & 100,00 & 0,000 \\
\hline
\end{tabular}

The same crude mixture was analyzed by HPLC coupled to LR-MS to confirm that the two compounds had the same $\mathrm{m} / \mathrm{z}$. The chromatographic profile was similar to the one observed in preparative HPLC and the two compounds showed identical $\mathrm{m} / \mathrm{z}$ (see below). ESI-LRMS : $[\mathrm{M}+2 \mathrm{H}]^{2+} \mathrm{m} / \mathrm{z}=705.3$ (calcd. for $\mathrm{C}_{66} \mathrm{H}_{90} \mathrm{~N}_{16} \mathrm{O}_{19}$ : 705.3). 


\section{Chomatogram}

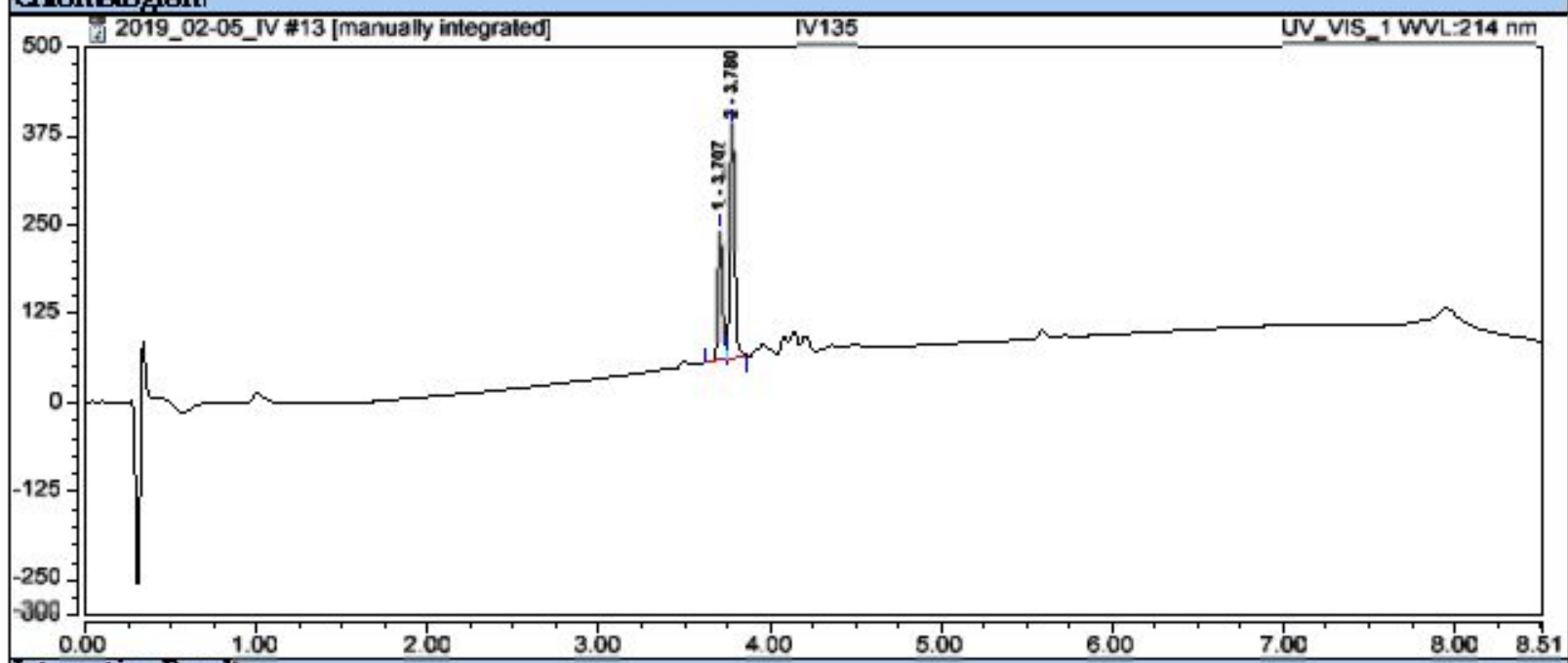

Integratimkesults

\begin{tabular}{|c|c|c|c|c|c|c|c|}
\hline$N_{0}$. & Peak Name & $\begin{array}{c}\text { Retention Time } \\
\text { min }\end{array}$ & $\begin{array}{c}\text { Are a } \\
\text { maUt "min }\end{array}$ & $\begin{array}{c}\text { Height } \\
\text { maU }\end{array}$ & $\begin{array}{l}\text { Relative sre a } \\
\text { \& }\end{array}$ & $\begin{array}{c}\text { Relative Height } \\
\text { \& }\end{array}$ & $\begin{array}{l}\text { Amount } \\
\mathrm{n} \text { a. }\end{array}$ \\
\hline $\begin{array}{l}1 \\
2\end{array}$ & & $\begin{array}{l}3.707 \\
3.780 \\
\end{array}$ & $\begin{array}{c}5.548 \\
10.346 \\
\end{array}$ & $\begin{array}{l}184.762 \\
329.632 \\
\end{array}$ & $\begin{array}{l}3491 \\
65.09 \\
\end{array}$ & $\begin{array}{l}35.92 \\
64.08 \\
\end{array}$ & $\begin{array}{l}\text { h a. } \\
\text { n . } 2 .\end{array}$ \\
\hline
\end{tabular}

Tota:

15.25

514394

1000
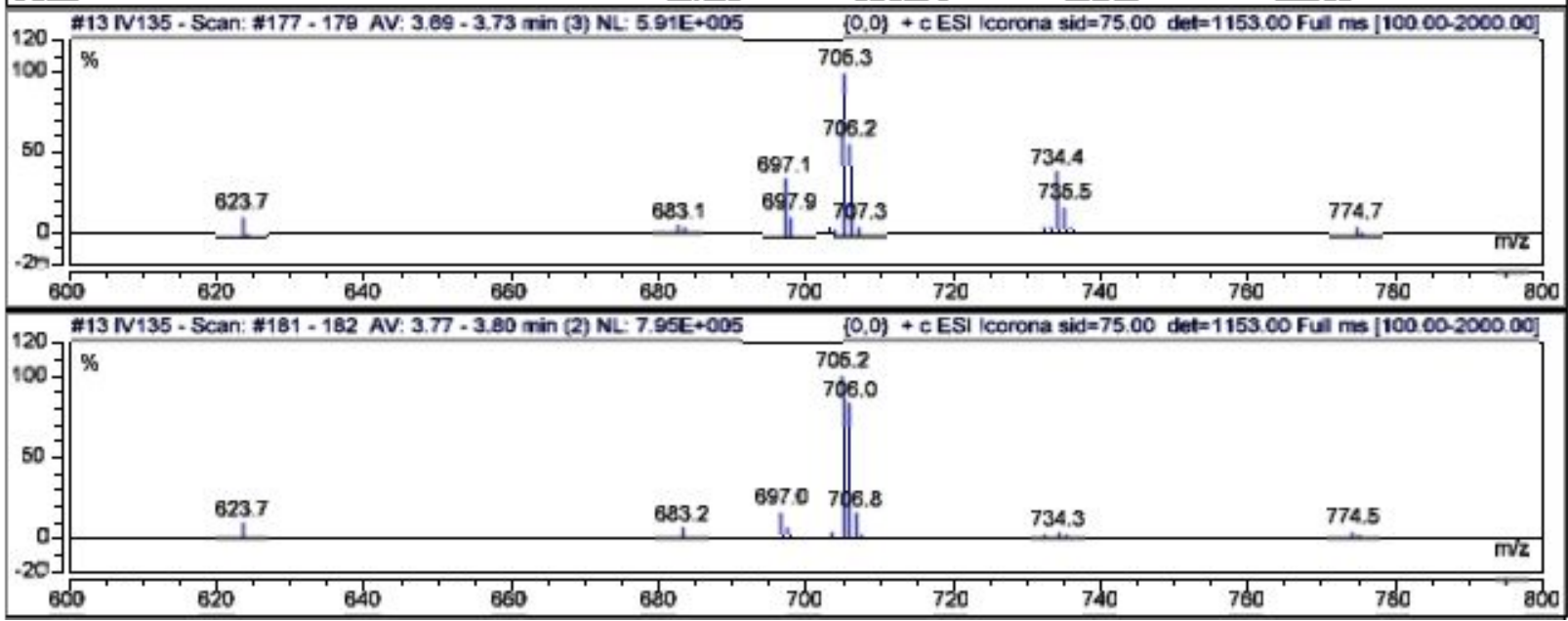


\section{HPLC chromatograms}

HPLC chromatograms of peptidomimetic 5 (absorbance in $A U$, retention time in minutes)
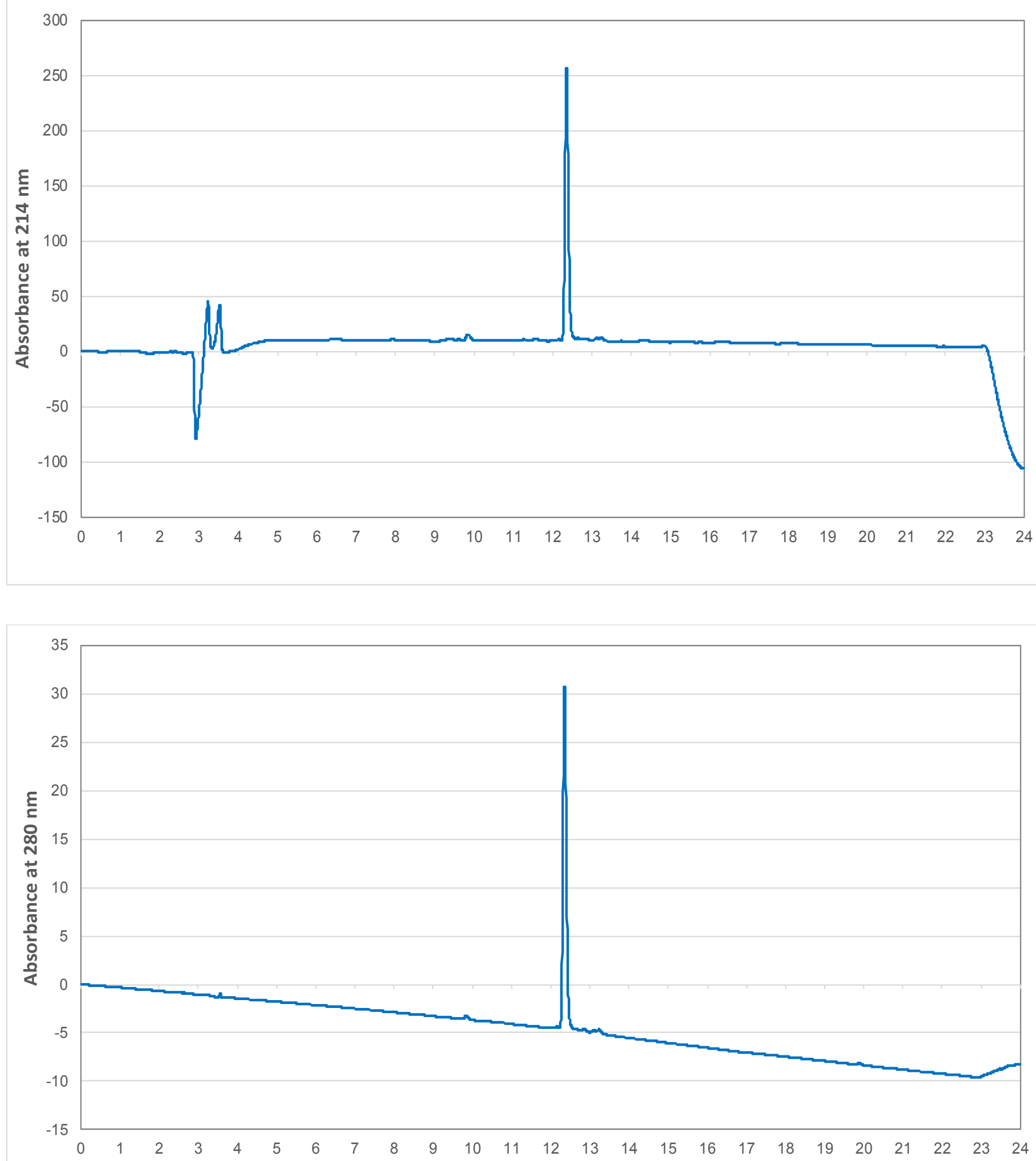
HPLC chromatograms of peptidomimetic 6 (absorbance in AU, retention time in minutes)
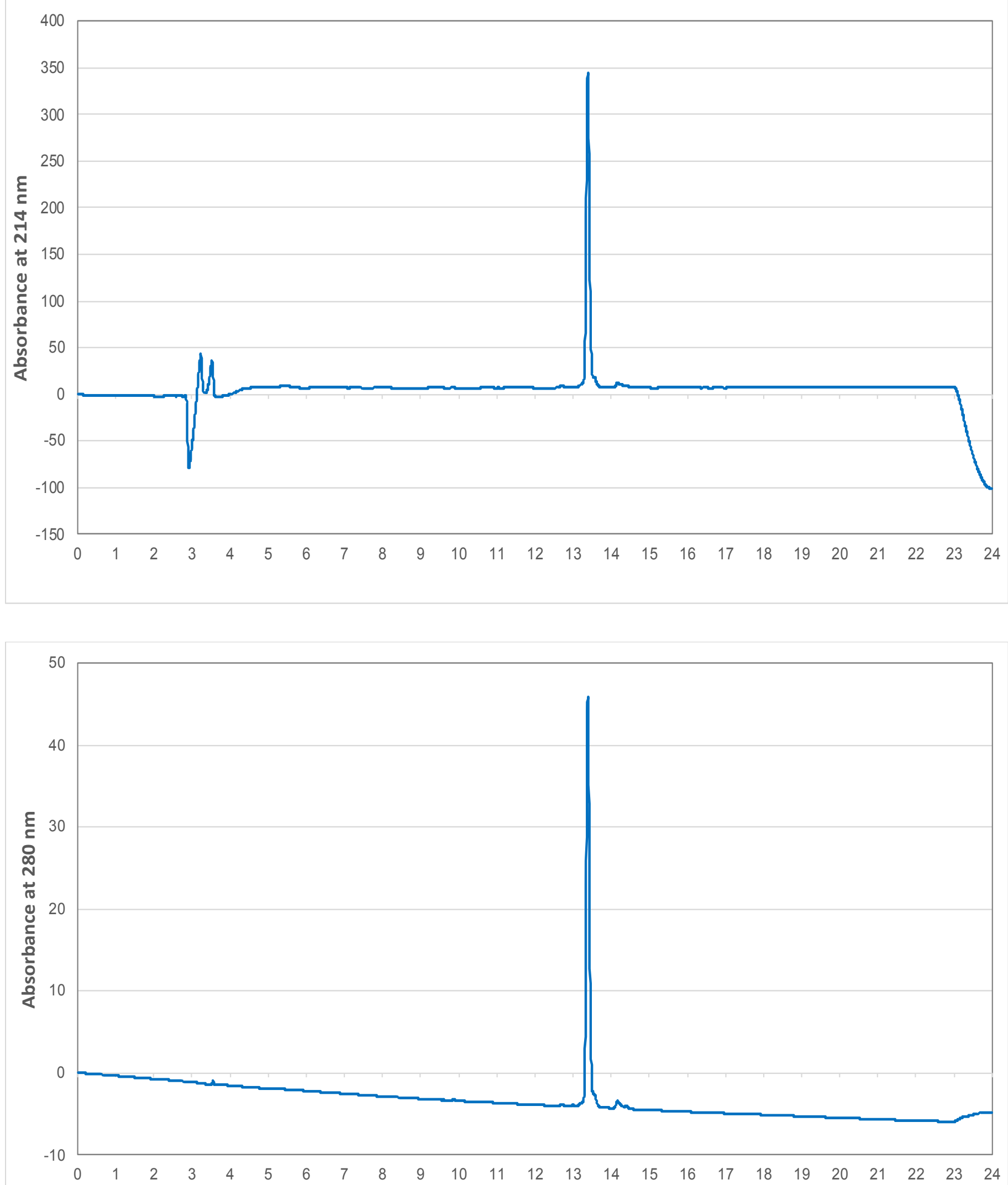
HPLC chromatograms of peptidomimetic 7 (absorbance in AU, retention time in minutes)
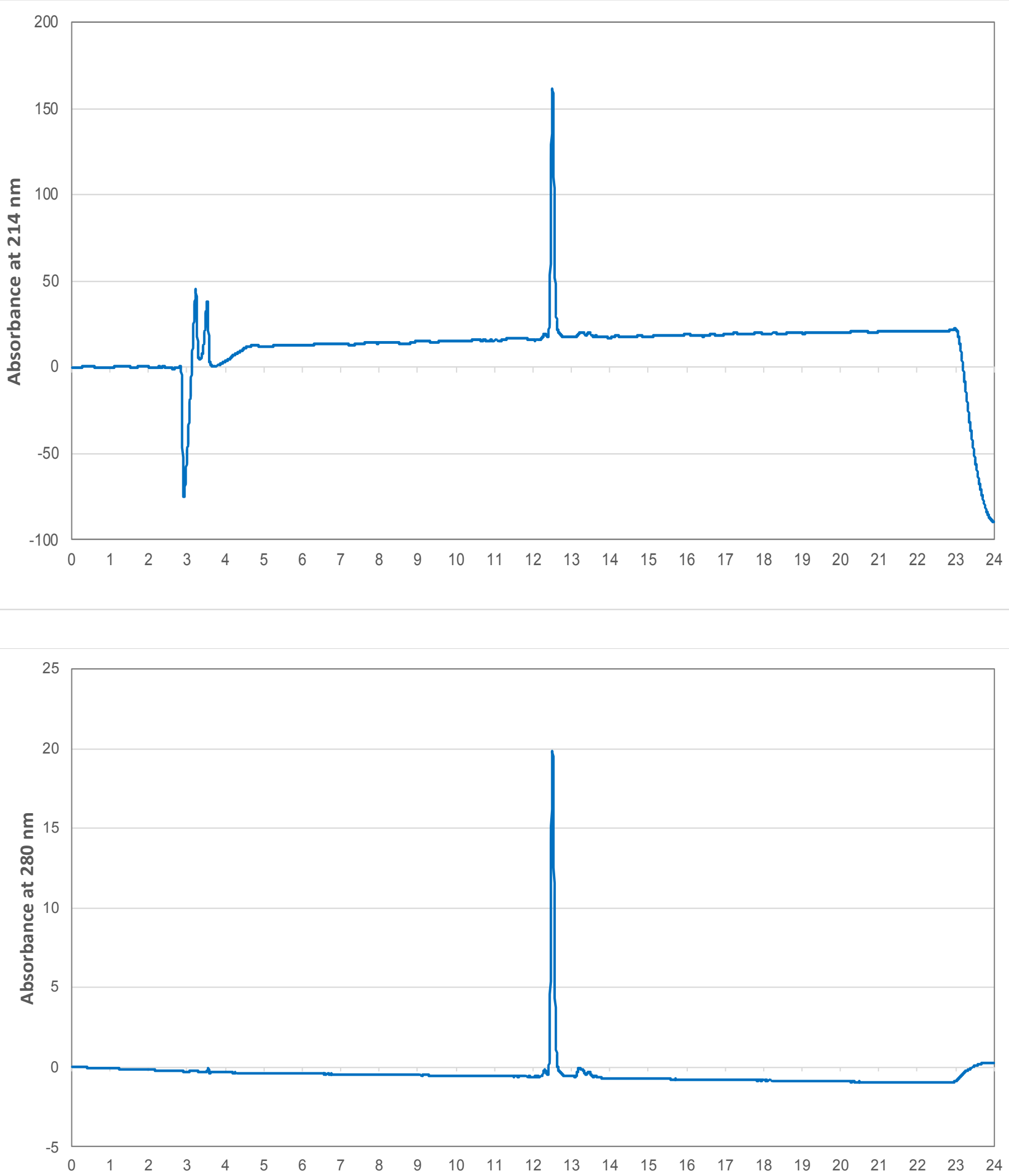


\section{MS spectra}

MS spectrum of peptidomimetic 5

3:IXcaliburldatal2019liv'19iv_134_3

5/28/2019 4:10:31 PM

\section{$\mathrm{CMMeOH}$}

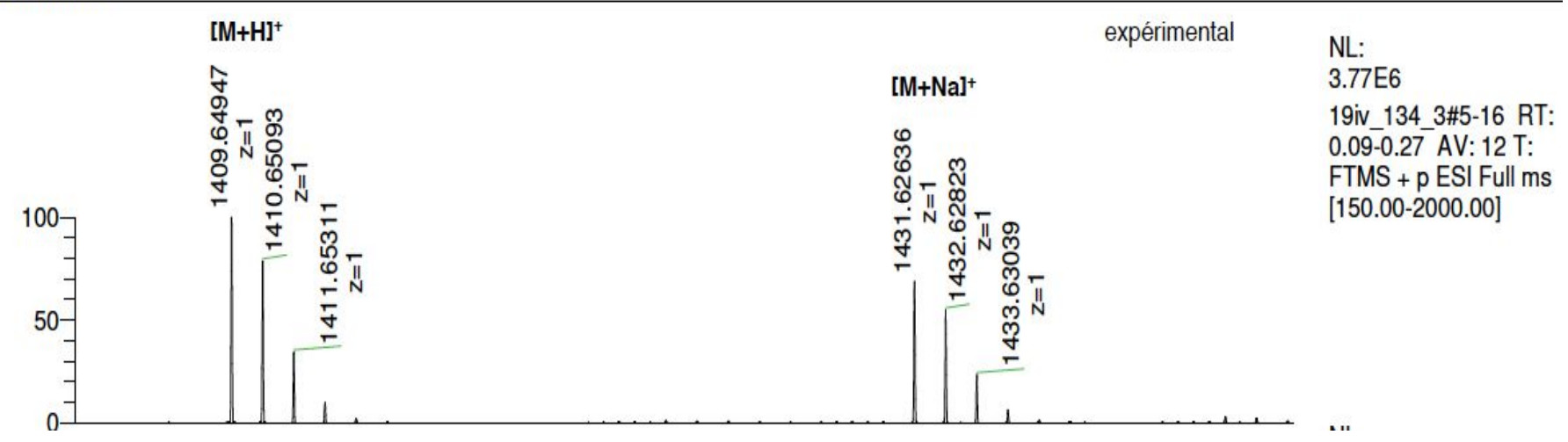

MS spectrum of peptidomimetic 6

\begin{tabular}{|c|c|c|}
\hline $\begin{array}{l}{\left[\mathrm{M}+\mathrm{Na}^{+}+\right.} \\
\stackrel{N}{N}\end{array}$ & expérimental & $\begin{array}{l}\text { NL: } \\
9.28 \mathrm{E} 4\end{array}$ \\
\hline 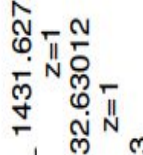 & & $\begin{array}{l}\text { 19iv_135_2\#5-20 RT: } \\
0.10-0.44 \text { AV: } 16 \mathrm{~T}: \\
\text { FTMS + p ESI Full ms } \\
{[200.00-2000.00]}\end{array}$ \\
\hline
\end{tabular}

MS spectrum of peptidomimetic 7

expérimental $\quad \mathrm{NL}$ :

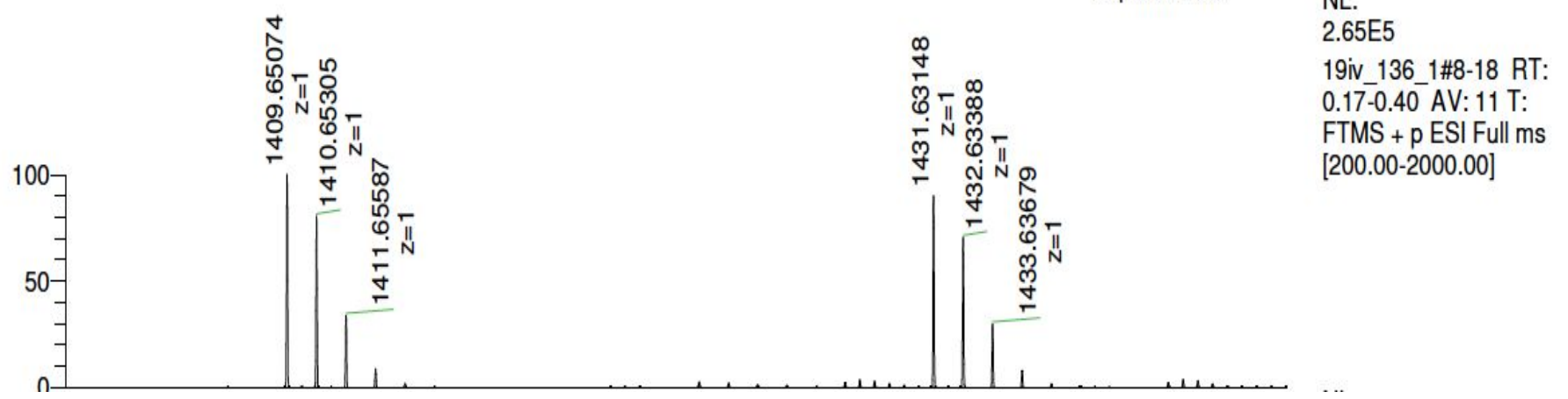




\section{Labeling with $\mathrm{LuCl}_{3}$}

WARNING: ${ }^{177} \mathrm{Lu}$ is a radioactive isotope emitting $\beta$ and $\gamma$ radiation with a half-life of 6.7 days. All procedures involving ${ }^{177} \mathrm{Lu}$ were conducted in a laboratory with appropriate equipment, and necessary safety measures were taken to limit exposure and contamination.

Stock solutions of the peptide conjugates were prepared by dissolving the conjugates in $25 \mathrm{mM}$ ammonium acetate in $\mathrm{H}_{2} \mathrm{O}$ to a final concentration of approximately $250 \mu \mathrm{M}$.

Labeling with $\left.{ }^{177} \mathrm{Lu}\right] \mathrm{Lu}^{3+}$ was performed in protein low-binding Eppendorf tubes. $12.5 \mathrm{MBq}$ (in vitro assays) or $25 \mathrm{MBq}$ (in vivo studies) of [ $\left.{ }^{177} \mathrm{Lu}\right] \mathrm{LuCl}_{3}$ in $0.05 \mathrm{M} \mathrm{HCl}$ was added to $0.5 \mathrm{nmol}$ of peptide conjugates $(2 \mu \mathrm{L}$ of $250 \mu \mathrm{M}$ stock solution) in aqueous ammonium acetate buffer $(100 \mathrm{mM})$ and sodium ascorbate $(50 \mathrm{mM})$. The labeling mixtures were heated for $20 \mathrm{~min}$ at $95^{\circ} \mathrm{C}$. Radiochemical yields were determined by $\mathrm{\gamma}$-HPLC (10-70\% A in B over $10 \mathrm{~min})$.

Labeling with [ ${ }^{\text {nat }} \mathrm{Lu} \mathrm{Lu}^{3+}$ was performed in protein low-binding Eppendorf tubes. A 5 -fold excess of [ ${ }^{\text {nat }} \mathrm{Lu}$ ] $\mathrm{LuCl}_{3}$ in $0.05 \mathrm{M} \mathrm{HCl}(125 \mathrm{nmol}, 12.5 \mu \mathrm{L}$ of $10 \mathrm{mM}$ stock solution) was added to $25 \mathrm{nmol}$ of peptide conjugates (100 $\mu \mathrm{L}$ of $250 \mu \mathrm{M}$ stock solution) in aqueous ammonium acetate buffer $(20 \mathrm{mM})$. The mixtures were heated for $20 \mathrm{~min}$ at $95^{\circ} \mathrm{C}$. 


\section{$\gamma$-Chromatograms}

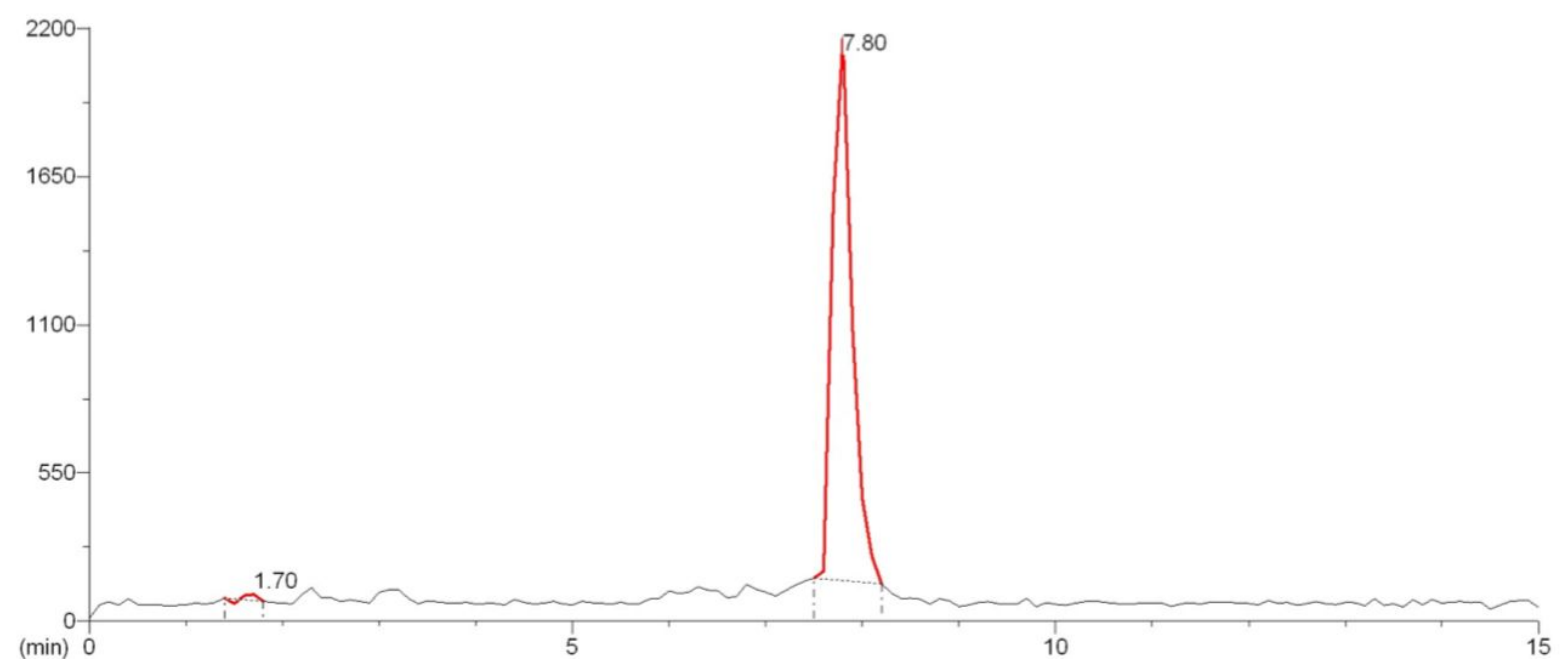

Representative $\gamma$-chromatogram of ${ }^{177}$ Lu-labeled $1,5-T z$ compound $\mathbf{5}\left(t_{r}=7.80 \mathrm{~min}\right)$.

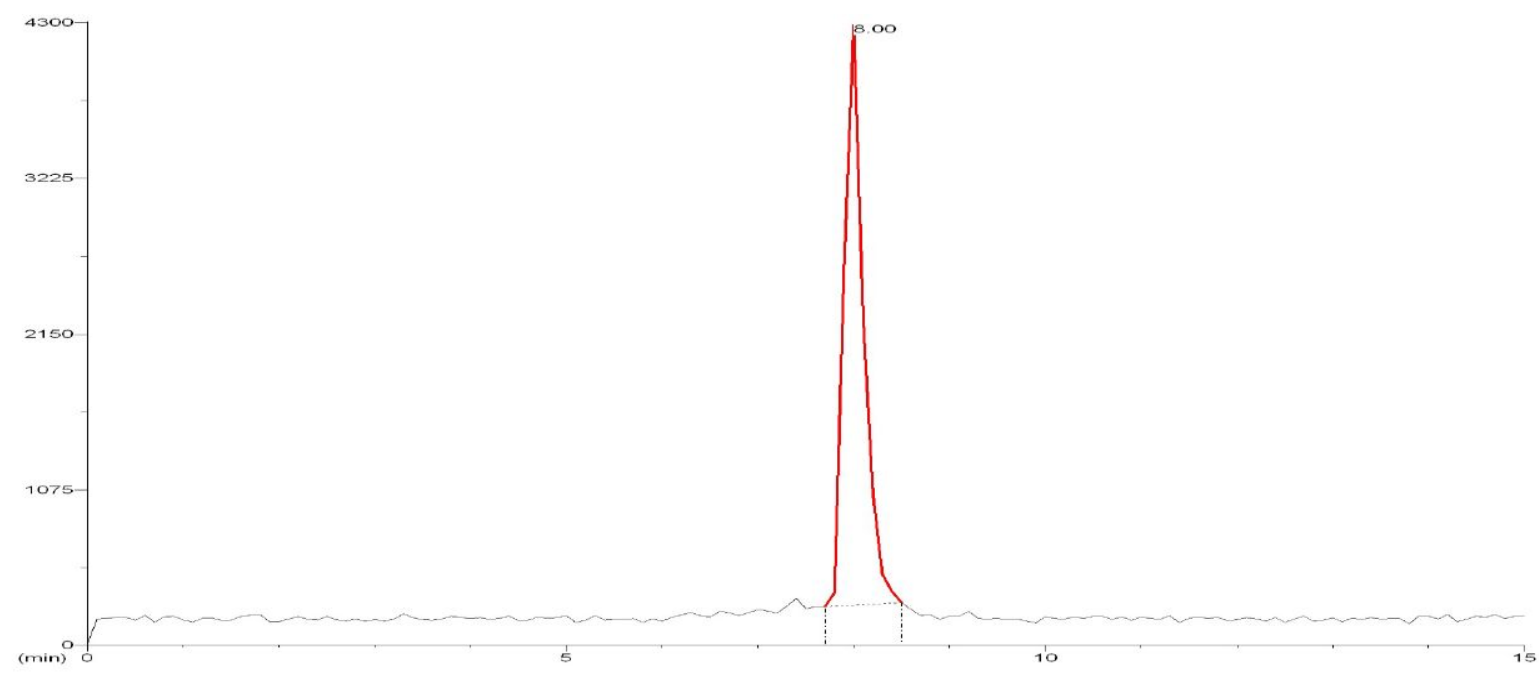

Representative $\gamma$-chromatogram of ${ }^{177}$ Lu-labeled $1,5-\mathrm{Tz}$ compound $6\left(t_{\mathrm{r}}=8.00 \mathrm{~min}\right)$.

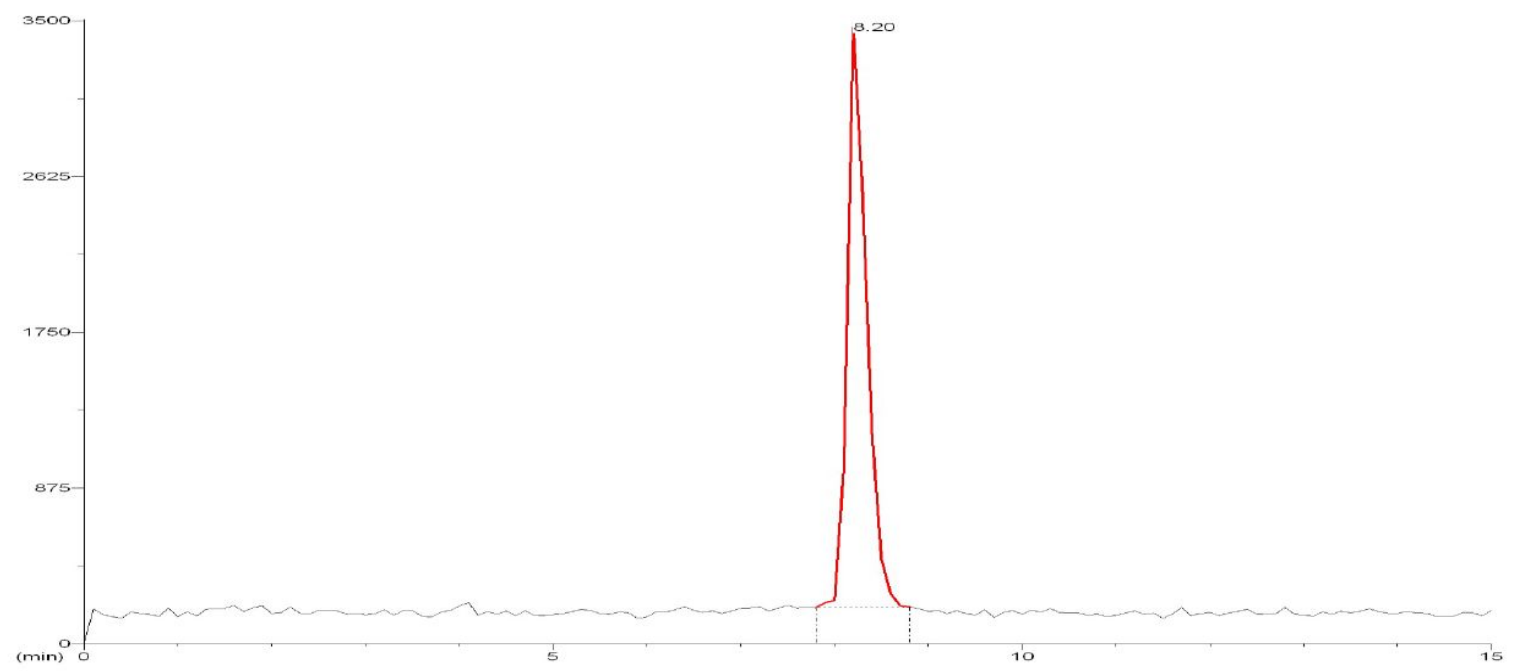

Representative $\gamma$-chromatogram of ${ }^{177}$ Lu-labeled 1,5 -Tz compound $7\left(t_{r}=8.20 \mathrm{~min}\right)$. 


\section{Cell Culture}

A431 cells from human epidermoid carcinoma expressing the CCK2R by stable transfection (A431-CCK2R cells $)^{2}$ were cultured in Nunclon Delta cell culture flask at $37{ }^{\circ} \mathrm{C}\left(5 \% \mathrm{CO}_{2}\right.$, humidified air). Cultures were kept in DMEM supplemented with FCS (10\%) and Gln $(20 \mathrm{mM})$ and passaged regularly at $80-90 \%$ confluency using trypsin $(0.25 \%)$ and EDTA $(0.038 \%$ ). In vitro assays were conducted in DMEM supplemented with BSA (0.1\%).

\section{Cell Internalization}

A431-CCK2R cells were seeded in six-well plates $\left(0.85 \times 10^{6}\right.$ cells/well in $2 \mathrm{~mL}$ culture medium $)$ on the day prior to the experiment and incubated overnight for attachment $\left(37^{\circ} \mathrm{C}, 5 \% \mathrm{CO}_{2}\right.$, humidified air). Cells were washed twice with $1 \mathrm{~mL}$ cold PBS prior to the experiments, and the plates were put on ice for preparation. $0.2 \mathrm{pmol}$ of ${ }^{177} \mathrm{Lu}$-labeled radioconjugates $(0.1 \mathrm{~mL}, 2 \mathrm{nM}$ in assay medium, ca. $4 \mathrm{kBq})$ were added to $0.9 \mathrm{~mL}$ of assay medium for total binding and internalization, or to $0.8 \mathrm{~mL}$ of assay medium and $0.1 \mathrm{~mL}$ excess minigastrin (10 nM in assay medium, 5000-fold excess) for blocking experiments. Cells were incubated at 37 ${ }^{\circ} \mathrm{C}$ for $30,60,120$, or $240 \mathrm{~min}$. Internalization was stopped by collection of the supernatant, and the cells were washed with $1 \mathrm{~mL}$ PBS twice to determine the unbound portion of applied radioactivity. Cells were subsequently incubated with $0.6 \mathrm{~mL}$ glycine buffer $(\mathrm{pH} 2.8,0.05 \mathrm{M})$ twice to remove the membrane-bound portion of radioactivity. Finally, cells were lysed with $0.6 \mathrm{~mL} \mathrm{NaOH}(1 \mathrm{M})$ twice representing the internalized portion of radioactivity. The radioactivity of each portion was determined by a COBRA-II gamma counter and binding/cell uptake is expressed as \% of applied dose of radioactivity. ( $n=3-4$ in triplicates)

Results are shown in the body of the article, blocking results are shown below (Figure S1).

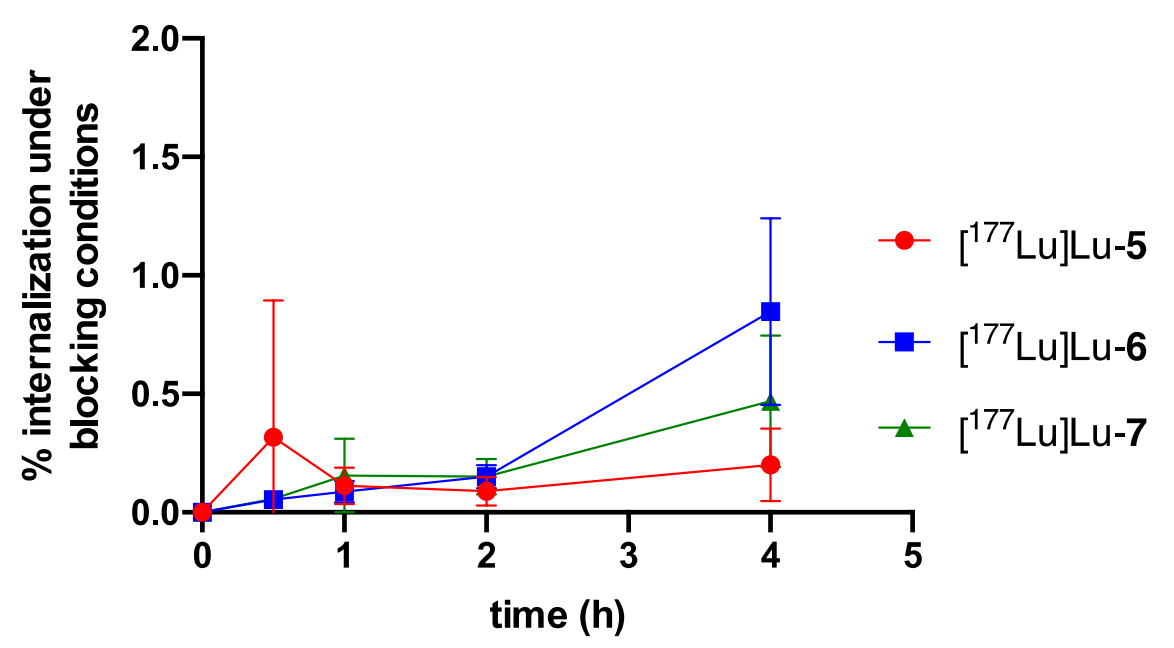

Figure S1. Blocking studies of ${ }^{177}$ Lu]5-7 using minigastrin as the blocking ligand on A431-CCK2R cells ( $n=3$ in triplicates)

\section{$\mathrm{IC}_{50}$ - Competition Binding}

A431-CCK2R cells were seeded in six-well plates $\left(0.85 \times 10^{6}\right.$ cells/well in $2 \mathrm{~mL}$ culture medium $)$ on the day prior to the experiment and incubated overnight for attachment $\left(37^{\circ} \mathrm{C}, 5 \% \mathrm{CO}_{2}\right.$, humidified air). Cells were washed twice with $1 \mathrm{~mL}$ cold PBS prior to the experiments, and the plates put on ice for preparation. Dilution series of nat Lu-labeled conjugates were prepared in assay medium from $5 \times 10^{-5}$ to $10^{-10} \mathrm{M},{ }^{177}$ Lu-labeled CCK2R-ligand PP-F1 $1 \mathrm{~N}^{9}$ was diluted from the radiolabeling mixture with assay medium to a $2 \mathrm{nM}$ solution. $0.8 \mathrm{~mL}$ and $0.9 \mathrm{~mL}$ assay medium were added to wells with competition binding and total binding, respectively. Competing conjugates $\left(0.1 \mathrm{~mL}, 5 \times 10^{-5}\right.$ to $10^{-10} \mathrm{M}$, except wells for total binding) and CCK2Rligand $(0.1 \mathrm{~mL}, 2 \mathrm{nM}, 5 \mathrm{kBq})$ were added to the wells subsequently, and the cells were incubated at $4{ }^{\circ} \mathrm{C}$ for $60 \mathrm{~min}$. To terminate the process, the supernatant was removed, and the wells were washed twice with 1 
$\mathrm{mL}$ cold PBS. Eventually, cells were lysed by dispensing twice $1 \mathrm{~mL} \mathrm{NaOH}(1 \mathrm{M})$ and collection of the lysate for determination of the radioactivity by a COBRA-II gamma counter. Cell binding is expressed as $\%$ of total binding in relation to concentration by normalized nonlinear regression. ( $n=3-4$ in triplicates).

Results are shown in Figure S2.

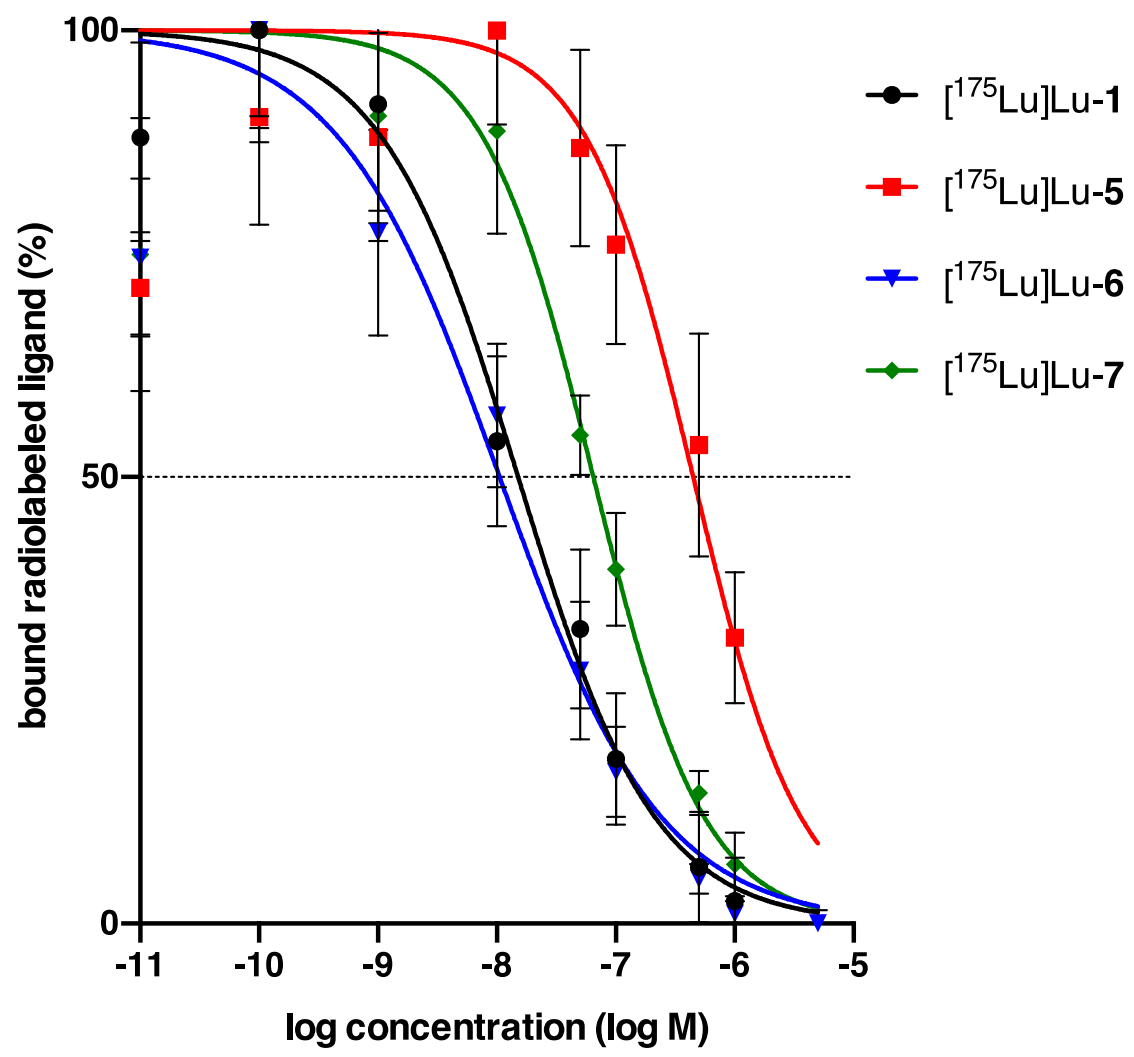

Figure S2. Competition binding of $\left[{ }^{175} \mathrm{Lu}\right] \mathrm{Lu}-5-7$ using $\left[{ }^{177} \mathrm{Lu}\right] \mathrm{Lu}-P P-F 11 \mathrm{~N}$ as the reference ligand to displace on A431-CCK2R cells $(n=3-4$ in triplicates).

\section{Plasma Stability}

Aliquots of human blood plasma stored at $-80{ }^{\circ} \mathrm{C}$ were slowly warmed to $37{ }^{\circ} \mathrm{C}$ prior to incubation. Compounds ${ }^{177} \mathrm{Lu}-5-7$ were diluted to $5 \mu \mathrm{M}$ with $0.9 \% \mathrm{NaCl}$ in water. $50 \mu \mathrm{L}$ of this solution (250 pmol) was added to $0.95 \mathrm{~mL}$ of human blood plasma in an Eppendorf tube, and the incubation at $37{ }^{\circ} \mathrm{C}$ was started. At $0.5,1,2,4,6$, and $24 \mathrm{~h}$, samples of $100 \mu \mathrm{L}$ were taken and precipitated by addition of $100 \mu \mathrm{L} \mathrm{MeCN}$. After centrifugation ( $3 \mathrm{~min}, 15996 \mathrm{RFC}, \mathrm{rt}$ ), $100 \mu \mathrm{L}$ of supernatant was diluted with $100 \mu \mathrm{L}$ MilliQ water prior to analysis by gamma-HPLC. Samples were analyzed with a $10-70 \% \operatorname{MeCN}(0.1 \%$ TFA) in water $(0.1 \%$ TFA) gradient over $25 \mathrm{~min}$, and metabolites were quantified by integration. Nonlinear regression (one phase decay) was used to calculate half-lives $\left(t_{1 / 2}\right)$ of the test compounds. $(n=2)$

Results are shown in the body of the article. 


\section{Biodistribution Studies}

6-week old female CD1 nu/nu mice were inoculated under anesthesia by isoflurane with $5 \times 10^{6} \mathrm{~A} 431$-CCK2R cells $\left(5 \times 10^{7}\right.$ cells $/ \mathrm{mL}$ in PBS, $0.1 \mathrm{~mL}$ ) subcutaneously in both shoulders 9-10 days prior to the experiment. On the day of the studies, mice were injected with the ${ }^{177} \mathrm{Lu}$-labeled test compounds $(0.1 \mathrm{~mL}, 10 \mathrm{pmol}$, ca $0.5 \mathrm{MBq}$ in PBS) via the tail vein. The animals were kept with water and food ad libitum. To determine unspecific uptake of the radiolabeled compounds, a 6000 -fold excess of minigastrin ( $60 \mathrm{nmol}, 0.1 \mathrm{~mL}$ in PBS) was injected prior to the test compounds. At $4 \mathrm{~h}$ post injection (p.i.) mice were sacrificed by $\mathrm{CO}_{2}$ asphyxiation. Organs and tissues of interest (blood, heart, lungs, spleen, kidneys, liver, pancreas, emptied stomach, emptied intestines, muscle, bone, tumors) were collected in pre-tared tubes, weighed, and the radioactivity was determined by a COBRA-II gamma counter. Uptake is expressed as $\%$ of injected dose of radioactivity per gram of tissue (\% ID/g). ( $n=4$ animals per group)

Table S1: Injected dose per gram of tissue (\% ID/g) for all collected tissues represented as mean +/-SD.

\begin{tabular}{lcccccc}
\hline & {$[177$ Lu $]$ Lu-1 } & $\begin{array}{c}\left.{ }^{177} \text { Lu }\right] \text { Lu-1 } \\
\text { (blocking) }\end{array}$ & {$\left[{ }^{177}\right.$ Lu $]$ Lu-6 } & $\begin{array}{c}{ }^{177 L u] L u-6} \\
\text { (blocking) }\end{array}$ & {$\left[{ }^{177 L u] L u-7}\right.$} & $\begin{array}{c}{ }^{[177 L u] L u-7} \\
\text { (blocking) }\end{array}$ \\
\hline Blood & $0.005 \pm 0.006$ & $0.010 \pm 0.000$ & $0.010 \pm 0.000$ & $0.008 \pm 0.010$ & $0.045 \pm 0.006$ & $0.043 \pm 0.013$ \\
Heart & $0.008 \pm 0.005$ & $0.013 \pm 0.005$ & $0.010 \pm 0.000$ & $0.013 \pm 0.005$ & $0.025 \pm 0.006$ & $0.023 \pm 0.005$ \\
Lung & $0.023 \pm 0.013$ & $0.030 \pm 0.000$ & $0.058 \pm 0.013$ & $0.043 \pm 0.010$ & $0.083 \pm 0.040$ & $0.048 \pm 0.022$ \\
Spleen & $0.030 \pm 0.008$ & $0.028 \pm 0.013$ & $0.035 \pm 0.006$ & $0.028 \pm 0.005$ & $0.050 \pm 0.008$ & $0.040 \pm 0.008$ \\
Kidneys & $0.643 \pm 0.067$ & $0.890 \pm 0.083$ & $0.830 \pm 0.061$ & $0.788 \pm 0.126$ & $0.808 \pm 0.032$ & $0.903 \pm 0.309$ \\
Pancreas & $0.065 \pm 0.019$ & $0.063 \pm 0.046$ & $0.078 \pm 0.028$ & $0.023 \pm 0.005$ & $0.033 \pm 0.010$ & $0.030 \pm 0.014$ \\
Stomach ${ }^{\text {pos }}$ & $0.563 \pm 0.171$ & $0.100 \pm 0.108$ & $1.510 \pm 0.794$ & $0.098 \pm 0.030$ & $0.140 \pm 0.020$ & $0.050 \pm 0.014$ \\
Intestines & $0.043 \pm 0.013$ & $0.048 \pm 0.028$ & $0.083 \pm 0.098$ & $0.043 \pm 0.005$ & $0.038 \pm 0.010$ & $0.065 \pm 0.010$ \\
Liver & $0.055 \pm 0.017$ & $0.303 \pm 0.386$ & $0.030 \pm 0.000$ & $0.035 \pm 0.006$ & $0.058 \pm 0.005$ & $0.070 \pm 0.027$ \\
Muscle & $0.023 \pm 0.025$ & $0.020 \pm 0.008$ & $0.028 \pm 0.035$ & $0.013 \pm 0.005$ & $0.015 \pm 0.006$ & $0.045 \pm 0.057$ \\
Bone & $0.038 \pm 0.010$ & $0.065 \pm 0.017$ & $0.043 \pm 0.013$ & $0.048 \pm 0.017$ & $0.040 \pm 0.012$ & $0.030 \pm 0.000$ \\
Tumor ${ }^{\text {pos }}$ & $1.579 \pm 0.720$ & $0.155 \pm 0.065$ & $3.868 \pm 0.755$ & $0.304 \pm 0.053$ & $0.801 \pm 0.257$ & $0.165 \pm 0.093$ \\
\hline
\end{tabular}

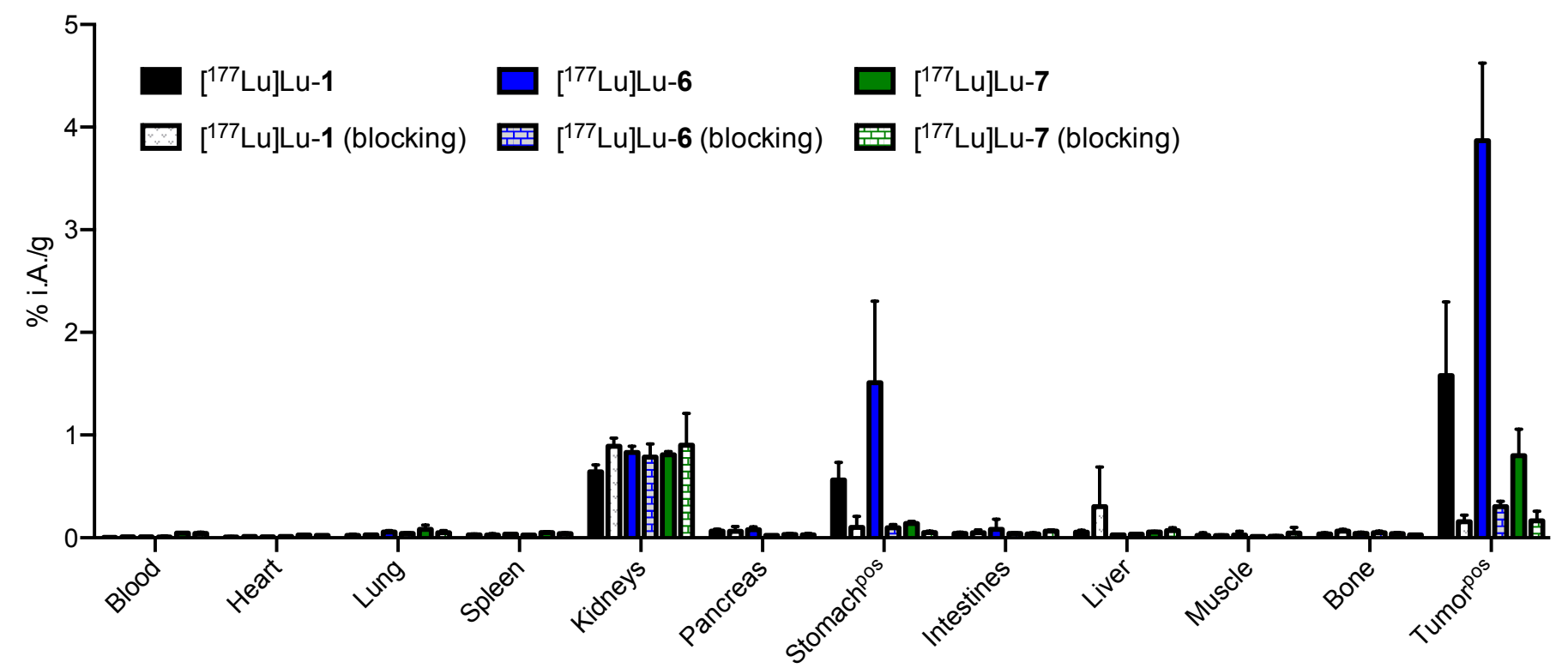

Figure S3: Injected dose per gram of tissue (\% ID/g) for all collected organs represented as mean +/-SD. 
(1) Grob, N., Haussinger, D., Deupi, X., Schibli, R., Behe, M., and Mindt, T. L. Triazolo-Peptidomimetics: Novel Radiolabeled Minigastrin Analogs for Improved Tumor Targeting, J. Med. Chem. 2020, 63, 4484-4495.

(2) Aloj, L., Caraco, C., Panico, M., Zannetti, A., Del Vecchio, S., Tesauro, D., De Luca, S., Arra, C., Pedone, C., Morelli, G., and Salvatore, M. In vitro and in vivo evaluation of 111 In-DTPAGlu-G-CCK8 for cholecystokinin-B receptor imaging, J. Nucl. Med. 2004, 45, 485-494.

(3) Fulmer, G. R., Miller, A. J. M., Sherden, N. H., Gottlieb, H. E., Nudelman, A., Stoltz, B. M., Bercaw, J. E., and Goldberg, K. I. NMR Chemical Shifts of Trace Impurities: Common Laboratory Solvents, Organics, and Gases in Deuterated Solvents Relevant to the Organometallic Chemist, Organometallics 2010, 29, 21762179.

(4) Mascarin, A., Valverde, I. E., Vomstein, S., and Mindt, T. L. 1,2,3-Triazole Stabilized Neurotensin-Based Radiopeptidomimetics for Improved Tumor Targeting, Bioconjugate Chem. 2015, 26, 2143-2152.

(5) Marchiori, M. F., Pires Souto, D. E., Oliveira Bortot, L., Francisco Pereira, J., Kubota, L. T., Cummings, R. D., Dias-Baruffi, M., Carvalho, I., and Campo, V. L. Synthetic 1,2,3-triazole-linked glycoconjugates bind with high affinity to human galectin-3, Bioorg. Med. Chem. 2015, 23, 3414-3425.

(6) Richter, F., Blomberg, R., Khare, S. D., Kiss, G., Kuzin, A. P., Smith, A. J. T., Gallaher, J., Pianowski, Z., Helgeson, R. C., Grjasnow, A., Xiao, R., Seetharaman, J., Su, M., Vorobiev, S., Lew, S., Forouhar, F., Kornhaber, G. J., Hunt, J. F., Montelione, G. T., Tong, L., Houk, K. N., Hilvert, D., and Baker, D. Computational Design of Catalytic Dyads and Oxyanion Holes for Ester Hydrolysis, J. Am. Chem. Soc. 2012, 134, 16197-16206.

(7) Kuhn, K. K., Littmann, T., Dukorn, S., Tanaka, M., Keller, M., Ozawa, T., Bernhardt, G., and Buschauer, A. In Search of NPY Y4R Antagonists: Incorporation of Carbamoylated Arginine, Aza-Amino Acids, or d-Amino Acids into Oligopeptides Derived from the C-Termini of the Endogenous Agonists, ACS Omega 2017, 2, 36163631.

(8) Pokorski, J. K., Miller Jenkins, L. M., Feng, H., Durell, S. R., Bai, Y., and Appella, D. H. Introduction of a Triazole Amino Acid into a Peptoid Oligomer Induces Turn Formation in Aqueous Solution, Org. Lett. 2007, 9, 2381-2383.

(9) Behe, M., and Schibli, R. (2015) Mini-gastrin analogue, in particular for use in cck2 receptor positive tumour diagnosis and/or treatment, (Pat., W., Ed.) A61K38/22 ed., Switzerland. 